\title{
Selected Socio-Economic and InternationaI Relations Issues in Contemporary Asian States
}

Edited by

Joanna Marszałek-Kawa Tadeusz Dmochowski 


\author{
Series \\ Asia-Pacific Library \\ Editor-in-Chief \\ Joanna Marszałek-Kawa
}

Secretary

Bartosz Ptotka

\title{
The Editorial Board \\ Kamal M. Abdulla (Azerbaijan), Daulet L. Baideldinov (Kazakhstan), Marceli Burdelski (Poland), He Yaomin (China), Hassan A. Jamsheer (Poland), Vasyl Marchuk (Ukraine), Joanna Marszatek-Kawa (Poland), Miao Huashou (China), Vladimir I. Nifadiev (Kyrgyzstan), Ewa Oziewicz (Poland), Zdzisław Puślecki (Poland), Akmal Saidov (Uzbekistan), Grażyna Strnad (Poland), Peter Vorel (Czech Republic)
}

\author{
Reviewers \\ Professor Jerzy Kornaś \\ Professor Renata Podgórzańska \\ Publishing editor: Pawet Jaroniak \\ Technical editing: Ryszard Kurasz \\ Proofreading: Team \\ Cover design: Krzysztof Galus \\ (c) Copyright by Wydawnictwo Adam Marszałek
}

All rights reserved. The book you have purchased is the work of the author and the publisher. No part of it may be reproduced in any manner whatsoever without permission in writing from the copyright owner. In case of brief quotations

of the work do not change the contents and make sure to note whose it is

Toruń 2020

\section{ISBN 978-83-8180-356-4}

The $7^{\text {th }}$ International Asian Congress "Building the Future of the State: Tradition, Reality, Progress" - a task co-financed under contract no. DNK/SP/466246/2020 from the Ministry of Science and Education funds allocated to the dissemination of science

Sales Department: tel. +48 5666422 35, marketing@marszalek.com.pl

Adam Marszałek Publishing House, ul. Lubicka 44, 87-100 Toruń tel. +48 5666422 35, e-mail: info@marszalek.com.pl, www.marszalek.com.pl Printing House, ul. Warszawska 54, 87-148 Łysomice, tel. + 48566783478 


\section{Table of Contents}

Preface

Wioleta Gierszewska

Relations Between China and Rwanda

\section{Zuzanna Sielska}

Balkan Game - Contemporary Relations of Serbia with Selected International Entities (Russia, USA, European Union, China)

\section{Małgorzata Polkowska}

Space Security in Asia-Pacific Region

\section{Adriána Gogová, Andrea Čajková}

Application of Selected Elements of Governance in the Chinese People's Republic as a Tool for More Efficient Governance of Public Administration in the Slovak Republic

\section{Martin Molčan, Andrea Čajková}

Management of Territorial Self-Government in the Slovak Republic in Comparison with Management of Territorial Self-Government in the People's Republic of China and Possibilities of Its Efficiency in the Slovak Republic 


\section{Marceli Burdelski}

Impact of External and internal Challenges

for political system and economy of North Korea

\section{Wojciech Mincewicz}

Central Bank Digital Currency as an Implementation of Distributed Ledger Technology: Digital Yuan Case Study

Krzysztof Marecki, Agnieszka Wójcik-Czerniawska

Cryptocurrencies in the Asian Financial Market

\section{Toghrul Allahmanli}

Main Characteristic of Main Export Industries of Azerbaijan

Kamila Rezmer-Płotka

Respecting Religious Freedom in India 2014-2018 182

Katarzyna Chałubińska-Jentkiewicz

Disinformation and Russian Issues 


\section{Preface}

The presented volume Selected Socio-Economic and International Relations Issues in Contemporary Asian States is a part of series published as conference proceedings after $7^{\text {th }}$ International Asian Congress (former Asian Conferences). The conference is organized annually by the Asia-Pacific Society in Torun.

The events have focused Polish and foreign researchers studying Asian issues in a broad spectrum of political, social, economic, and cultural phenomena, including international relations at the bilateral and multilateral levels.

The volume includes several groups of issues. The first concerns political relations, both bilateral ones (China-Rwanda, Serbia-Russia, the US, the UE, China), security in the Asia-Pacific region, and absorption and interference of influence exerted by the states on political regime's changes, and the internal modernization of other states (Slovakia-China, Northern Korea - internal and external challenges).

The second group includes papers about Central Bank's digital currency supported with the examples of digital yuan and cryptocurrencies on the Asian financial market.

The third group includes other papers that are about Azerbaijan, religious freedom in India, and disinformation politics of the Russian Federation.

The volume is opened by the paper "Relations Between China and Rwanda" written by Wioleta Gierszewska who analyzes bilateral relations of the People's Republic of China and Rwanda. In the 1990s, China began to systematically 
increase its political and economic presence in Sub-Saharan Africa, including Rwanda. The author highlights the genocide of 1994 that has complicated relations between the states. Back then, China, like France, supported Rwandan government, considered responsible for the Tutsi massacre by the international community. The author noted that after the domestic war in Rwanda, the PRC apologized the world for its participation in the conflict and offered help to Rwanda to rebuild the country. Since then, relations between the countries have changed. China's engagement in Rwanda depends on non-interference in political issues.

The author stresses that nowadays cooperation between China and Rwanda focuses on achieving common benefits from commercial exchange and Chinese investments in the African soil. In the paper, attention is drawn by the analysis of positive and negative aspects of this cooperation. Considerations end with a conclusion that the mutual relations bring development and technological progress of the African country, and highlights not always good quality of mutual projects and results of unequal competition embodied by the bankruptcy of many local companies.

Rwanda perceives China as a model of economic development. The author claims then the model privileges stability and economic growth which will dominate mutual relations between China and Rwanda.

Zuzanna Sielska, in the paper entitled "Balkan Game Contemporary Relations of Serbia with Selected International Entities (Russia, USA, European Union, China)", analyzes relations between Serbia and Russia, the United States, the European Union, and China. She presents problems and challenges with which the Serbian government has to deal with within relations with the indicated international ac- 
tors. Having the opportunity, the author addressed the issue of "vaccine diplomacy" that significantly impacts relations between the states.

The paper "Space Security in Asia-Pacific Region" written by Małgorzata Polkowska indicates a growing concern about space security in the Asia-Pacific region in which dynamic changes have a negative impact. In the context of space, there is an "arms race" toward military using of space for creating military asset or at least balance of deterrents. States accepting the American challenge in this area are the Russian Federation and China which try to decrease American advantage "on the ground" by developing their military potentials in the space. The author argues that tensions in the Asia-Pacific may be reduced by creating a system of space awareness that would enable secure utilization of space and stop its degradation. The latter would be beneficial for all states.

Adriána Gogová and Andrea Čajková wrote the paper entitled "Application of Selected Elements of Governance in the Chinese People's Republic as a Tool for More Efficient Governance of Public Administration in the Slovak Republic". They focus on public administration as an organizer of public life, a set of offices-units operating for public interest, and the set of executive units with which each citizen deals every day. Public administration undergoes constant changes resulting from constantly emerging new tasks. Based on a theoretical background, the authors aim to analyze selected management mechanisms used in the People's Republic of China and consider their transfer to Slovakia. After thorough and comprehensive analyzing the topic, the authors concluded that implementing some Chinese management mechanisms in Slovakia would increase 
the effectiveness of the functioning of Slovakian public administration due to elimination of corruption, clientelism, and political influence.

Martin Molčan and Andrea Čajková wrote the paper entitled "Management of Territorial Self-Government in the Slovak Republic in Comparison with Management of Territorial Self-Government in the People's Republic of China and Possibilities of Its Efficiency in the Slovak Republic". Before writing it, they had assumed that local self-government is a part of public administration and engaged in solving problems and local issues realized by territorial structures and organizations. Given that, a territorial self-government has competences and rights necessary for making decisions concerning its competence scope. A basic unit of territorial self-government is a commune, which makes it also the smallest public unit in the state. The paper aim is to compare mechanisms of territorial self-government management in the People's Republic of China and the Slovak Republic. Another step was choosing from them management mechanisms that could be transferred from the PRC to Slovakia. A literature review focused on analyzing management and seeking methods and procedures that would facilitate the functioning of public administration in the Slovak Republic, which could enhance its effectiveness, improve task realization, and more transparent spending of public money.

Marceli Burdelski in his paper "Impact of External and internal Challenges for political system and economy of North Korea" indicates the stability of political aims of Kim family that tend toward maintaining the dynasty's rules, controlling society, e.g., in terms of the access to the media, maintaining the isolation of North Korea, using nuclear weapon as a deterrent, and receiving external help. 
The author also indicates dangers for Kim Jong Un's leadership, by pointing out four areas: damages caused by the COVID-19 pandemic; growing economic problems associated with sanctions imposed by the United Nations Security Council; inefficient foreign policy toward the United States, Southern Korea, and the European Union; and natural disasters - including floods and typhoons. Moreover, the complete isolation of North Korea since January 2020 has caused commercial (lack of export to Russia and China), diplomatic, and image loses - North Korea closed its borders to the citizens of other states and West European countries withdrawn even the diplomatic missions' personnel.

Wojciech Mincewicz in the paper entitled "Central Bank Digital Currency as an Implementation of Distributed Ledger Technology: Digital Yuan Case Study" aims to analyze the project of digital currency of the People's Bank of China based on the example of digital yuan. The paper is divided into two parts. The first one presents reasons behind beginning works on fiduciary money - namely, fiat currency. After analyzing cases of several states, the author concluded that the reasons were: the digital transformation of societies, stepping away from cash, struggle against hyperinflation, increasing security of financial operations, and - currently - fight against the consequences of the COVID-19 pandemic. In the second part, the author analyzes positive outcomes and possible dangers for the PRC associated with introducing digital currency by the People's Bank of China, and society's digitization. The author indicates two possible scenarios. The first assumes that digital currencies are created to complement the circulation of traditional money. The second is the opposite of the first and assumes that the 
People's Bank of China will completely withdraw cash from circulation and replace it with digital currency.

"Cryptocurrencies in the Asian Financial Market" is the title of a paper written by Krzysztof Marecki and Agnieszka Wójcik-Czerniawska. The authors present the growing meaning of cryptocurrencies. Currently, there is over a thousand cryptocurrencies in the world and one can assume their number will further increase given their enormous popularity. The first such a currency was Bitcoin introduced in 2008 to support peer-to-per exchange. It was named as cryptocurrency because in the process of its creation was engaged cryptography (common technique depending on blockchains). "Virtual currencies" have become parts of companies and people's portfolios.

The first such institutions were Black Rock and Goldman Sachs. The authors consider the functioning of cryptocurrencies on Asian financial markets and conclude that in some of these states, such as China, India, Singapore, Vietnam, Thailand, and South Korea citizens perceive cryptocurrencies as an opportunity for decentralizing means of payment since they are independent of central national economies. Simultaneously, the authors indicate that the legal status of cryptocurrencies in many Asian states remains unclear.

Toghrul Allahmanli, in his paper "Main Characteristic of Main Export Industries of Azerbaijan", very generally considered a relation between Azerbaijan's economic potential, its sovereignty, and aim realization. The economic potential of that state enhances its independence, increases its interests' protection, and, in consequence, the realization of the national interests of Azerbaijan on the domestic and international platform based on values positively tested in other countries. 
Kamila Rezmer-Płotka in the paper "Respecting Religious Freedom in India 2014-2018" took for caesuras the first term of office of Prime Minister Narenda Modi (a member of Bharatiya Janata Party and a nationalist Hindu organization Rashtriya Swayamsevak Sangh, considered the largest non-governmental organization in the world). Formally, India has a democratic regime and declares to be a secular state. However, practically, it is a state dominated by Hinduism. The author indicated that in the period under investigation, in India freedom of religion was infringed in all possible aspects of that kind of freedom, namely, freedom of choosing religion, changing a belief, or rejecting it; freedom of coercion; and the right to manifest religious beliefs. All that narrow down to a conclusion that the declared democratic principles and the state's secularity are not followed at the level of everyday practice.

In the last paper, written by Katarzyna ChałubińskaJentkiewicz and entitled „Disinformation and Russian Issues", the author investigates the problem of the Russian politics of disinformation, important from the perspective of international politics and the security of Poland. Also, she indicates that the aim of that kind of politics is to influence on, among others, strategic groups responsible for state management, governance, security structures, and social groups not to destroy them but to take control over their way of thinking through inspiring and organizing; thus, to gain impact on decisions made by key decision-makers. The aim of these actions is to inspire and enhance collective behaviors and attitudes desired by the disinforming groups. Inspiring discontent, reluctance, anger, and disappointment against actions taken by the government may impact changing a decision or cause an anxiety of making decisions that 
would be necessary for ensuring safety for citizens. In result, such decisions are not made due to the fear of "social" (in fact, inspired) discontent.

The author discerns the decrease of the meaning of traditional media, an opposing trend in the Internet, and forms emerging in its area, e.g., social media (such as Twitter, Facebook, Instagram) that "created" new areas of danger. Opinions and attitudes expressed in social media often are catalysts of social disturbances that can be caused by two kinds of reasons. First is the expression of the authentic civil resistance, and the second may be inspired by an interest group, other governments and their services. According to the author, a state that utilizes disinformation politics fluently is Russia.

Joanna Marszałek-Kawa Tadeusz Dmochowski 


\section{Wioleta Gierszewska}

University of Gdańsk

ORCID ID: https: / / orcid.org/0000-0002-5024-9379

\section{Relations Between China and Rwanda}

In the 1990s, China began to increase its presence in sub-Saharan Africa systematically. The involvement of the Middle Kingdom was driven by the need to obtain natural resources and access to local consumer markets. Although Rwanda does not have many raw materials, it borders on countries rich in natural resources, and it occupies a strategic place in the region, as it is a relatively stable and developing country. Unlike some neighboring countries, especially those considered failed, such as the Democratic Republic of Congo or Burundi, it is relatively safe to conduct any business investment in Rwanda. Diplomatic relations between the People's Republic of China and Rwanda were established on November 12, 1971. They resulted in joint initiatives in education, health, culture, and above all in various sectors of the economy. In 1983, China built a hospital in the former Kibungo Province (now the Eastern Province). The Middle Kingdom supported the Rwandan government without interfering in the internal affairs of this country, such as human rights violations, also in the course of ethnic quarrels. For example, the French and Chinese sold machetes to Rwanda during the Tutsi-Hutu ethnic conflict. For almost the entire last century, Rwanda was a poorly managed country, and internal destabilization was supported by Western countries and some Asian countries. Rwandan colonial regimes, and then postcolonial ones, ruled by inciting social 
conflicts, especially inter-ethnic ones. Pre-colonial values of local communities were effectively destroyed by implementing European, racist-laden management patterns. As a consequence, Rwanda has become one of the poorest and most divided countries in the world ${ }^{1}$.

1994 was a breakthrough in Rwanda's international relations. The Rwandan Patriotic Front took control of the country, which resulted in a change of governments and the introduction of changes in the political and economic sphere $^{2}$. The two most important are: making strenuous efforts to bring about unity in Rwandan society, mainly by appealing to pre-colonial social values and the economic development of the country ${ }^{3}$. Despite the events of 1994, China did not intend to give up its influence in the region, and Rwanda needed help rebuilding the country. When starting to implement their plans, the Chinese first took initiatives to honor those murdered in the ethnic conflict and then proposed many joint economic initiatives to rebuild the ruined country. Moreover, they were the first country to re-open its embassy in Kigali after the conflict. Medical teams from China treated the sick and trained doctors. The Chinese government has offered Rwandans scholarships for students in various fields of study. He pledged to provide funds to improve the state of agriculture in Rwanda. Thanks to technical assistance, rice cultivation was introduced and developed in the Rwamagana and Umutara regions.

1 J.P. Chretien, The Great Lakes of Africa. Two thousand Years of History, New York 2006, pp. 317-346; J. Bar, Po ludobójstwie: państwo i społeczeństwo w Rwandzie 1994-2012, Kraków 2013, pp. 48-50.

2 J. Bar, Rwanda, Warszawa 2013, pp. 68-87.

3 The Diplomatic Magazine. Minaffet Ministry of Foreign Affairs and Cooperation, Kigali 2009. 
The Chinese system based on state capitalism allows implementing large infrastructure projects at lower costs than the international competition. As a result, ever since China started investing in Rwanda, the country has been much more successful in economic development ${ }^{4}$. In his speeches, Paul Kagame repeatedly emphasized that "Cooperation with China is a good partnership that maintains the demand for business and investments in the region" ${ }^{5}$. It is also confirmed by Vivian Kayitesi - Director of Investment Promotion at the Rwanda Development Board. According to Kayitesi, the main areas of Chinese investment in Rwanda are construction, real estate, hotels, and the telecommunications industry. From 1994 to 2014, Chinese investments amounted to nearly $\$ 200$ million.

Over the past few years, Rwanda's trade with China has grown faster than any other country. Rwanda's imports from China included electronics, building materials, footwear, clothes, and production machinery, including materials such as bricks, bags, and tea. China mainly imports raw hides and minerals from Rwanda. For example, Rwanda exports $10 \%$ of its tin ore (valued at $\$ 3.8$ billion), $42 \%$ of niobium and tantalum (valued at $\$ 8.2$ billion), and $57 \%$ of tungsten ore ( $\$ 10.2$ billion) imported into China ${ }^{6}$. Chinese engineers designed

4 J. Gu, A. Carty, China and African Development: Partnership not Mentoring, "Institute of Development Studies" 2014, vol. 45, no. 4, pp. 57-69; K. Nanda, New 'Friends' of Rwanda - Chinese Noodles and Indian Curry: An Analysis of Asian Giants' Forays into Rwanda in the Light of Theories on OFDI, [in:] Rwanda Fast Forward, eds. M. Campioni et al., London 2012, pp. 145-146.

5 P. Kagame, Remarks by president Kagame at $5^{\text {th }}$ investing in Africa Forum, http://paulkagame.com/?p=14722 [access: 15.01.2020].

6 D. Nzohabonimana, Boom Town: Kigali's Chinese investment, https://www.pambazuka.org/governance/boom-town-kigali\%E2\%80\% 99s-chinese-investment?_cf_chl_captcha_tk__=90cc9b73307fe6db- 
and built the country's tallest building, the Kigali City Tower (a 20-story glass skyscraper) and - as China's ambassador to Rwanda emphasized $-80 \%$ of the roads. In addition, the Chinese Ministry of Education is building Confucius Institutes where Rwandans will learn Chinese. Every year, hundreds of Rwandan students receive scholarships to study in the Middle Kingdom. The \$27 million government building complex in Kigali is a gift from the Chinese authorities to Rwanda. Rwandan Prime Minister Édouard Ngirente, appreciating the value of the gift, stated that it is: "another indicator of how relations between China and Rwanda are strengthening". The seat of government, some industrial complexes, and a significant amount of housing for the emerging middle class were built mainly by the Chinese. These projects have been marked with red flags, stars, and plaques that testify and remind of the growing share of Chinese investment in Rwanda and the region ${ }^{7}$. It is also evidenced by creating the economic sphere on the outskirts of Kigali's "Prime Economic Zone". The industrial center was built mostly by Chinese companies, including China Star Construction Co. Ltd. It has been the

bc7cb85113dda0e98a534b93-1580554790-0-AaU-Q_TOQEZje18kj3Hw7vDUaSfMkll5UbWN9eJZqLRF3hRp35LgB-OuCY6NGFBbfENjftLmVlyOcYkSu8B3vGRd6KYnV9gDxq4O8_jiDmgnYhm-ldfjUWzCshiF8yaEhg4LgrWr_DOBOIkQbta5LFcAU3yOtHRCXdKwPM3QmmfpPdLvwLAakZzUVdp7zxOaoTs3f26htbdImDZlcEaINh5lsJv1Pk_ 28jNx2Fpuplhed-Pff26o2qS7bQLtoHlD5xfvs-X4QVmNOl3CZiqrrSAT3hJ5OQYnTpKbTb8tpS1q9nJVKRNpR471rX6DP1OU8oSkv2rIxnMSRCNmMTV_1opjyedtnMm0Hwz_GIUtWxnLNTfE7foB_QjYcvjGNhPaCZzchÄk0lbdgGHXSNEiSjWPrKRE9p3HuBY0TXmP8rRF5xx61m5Sc3PZ1qoKxkyxg [access: 14.07.2019].

7 In the whole Sub Saharan region number of Confucius Institutes and education projects increases. Ł. Firmanty, op.cit., pp. 188-189; S. Paduano, China's Investments in Rwanda Raise Familiar Questions About Debt, https://www.msn.com/en-gb/news/other/chinas-investments-in-rwanda-raise-familiar-questions-about-debt/ar-AAFhUSA [access: 16.11.2019]. 
engine of economic growth in recent years. Tens of millions of dollars also flow into the underdeveloped eastern province of Rwanda, where China is financing and building three multi-thousand stadiums.

China's presence is also visible in other areas of the country's life. Like China, Rwanda has adopted a system of central economic planning. Units of the Rwandan army speak Chinese and are trained by the Chinese ${ }^{8}$. In turn, the Rwandan government rejected the principles of liberal democracy, lifting restrictions on the exercise of power for its longtime leader, President Paul Kagame. At the ChinaAfrica Cooperation Forum summit in September 2018, Tern stressed that: "Relations between Africa and China are based on equality, mutual respect and a commitment to shared prosperity. Everyone who plans to do business on the continent benefits from it, and China has proved with its support and investments that it is a sincere friend" 9 . Kagame has repeatedly emphasized that cooperation is facilitated by the similarity of historical sufferings and experiences. Importantly, Africans see themselves as standing in the way of prosperity and are treated as such by the Chinese ${ }^{10}$.

For Rwanda, China is an attractive investment and aid partner in various sectors of the country's life. Private Chinese consortia and entrepreneurs invest in real estate, telecommunications, manufacturing, and the development of small local businesses such as restaurants, imported car

8 Ibidem.

9 P. Kagame, President Kagame attends Opening of China-Africa Cooperation Summit, http://paulkagame.com/?p=13338 [access: 15.01.2020].

10 Idem, Remarks by president Paul Kagame at the State banquet in Honors of President XI Jinping of the People's Republic of China, http:// paulkagame.com/?p=13133 [access: 15.01.2020]. 
dealerships, and travel agencies. Large Chinese state-owned enterprises build most roads and invest in infrastructure in Rwanda. At the same time, Chinese involvement is not determined by obtaining the right to exploit small deposits of local oil and natural resources in return, as is the case in other African countries ${ }^{11}$. From its natural resources, China imports a relatively small amount of minerals from Rwanda, which is the leading exporter of tantalum, a metal used in mobile phones.

China's involvement in the Sub-Saharan Africa region is the subject of many debates by scientists and specialists dealing with forecasting international relations ${ }^{12}$. The councils revolve around xenophobic attitudes towards the Chinese, mainly in Zambia, Ethiopia, and Algeria. The culprit are Chinese immigrants willing to take up any job for a competitively low wage compared to the local population. They are often accused, especially by American researchers, of the problem of neo-colonization of the countries in which they find themselves. In turn, this is contradicted by China's spending and investments in countries poor in raw materials, such as Rwanda ${ }^{13}$.

Western politicians and economists accuse China of plunging African states into debt and making them de-

11 L. Kuo, Rwanda is a landlocked country with few natural resources. So why is China investing so heavily in it?, https://qz.com/africa/827935/rwanda-is-a-landlocked-country-with-few-natural-resourcesso-why-is-china-investing-so-heavily-in-it/ [access: 19.08.2019].

12 Tidiane N'Diaye claimed that most analysts negatively assess Chinese politics in Africa. T. N'Diaye, Żótte i czarne: historia chińskiej obecności w Afryce, Warsaw 2016, pp. 195-196.

13 Rwanda is a small country, without access to a sea and natural resources. With two times smaller population than Beijing it is not the best market for Chinese products. V. Byusa, Chinese external assistance to Rwanda, "NUR- Rwanda Journal" 2010, vol. 19, series B, pp. 66-83. 
pendent on cooperation with the Middle Kingdom. Many believe that Chinese investment threatens to build African prosperity and national sovereignty. The quality of Chinese projects is also controversial. For example, in Rwanda, since 2011, more and more nightclubs and cafes have been built using Chinese materials that do not meet safety standards. In 2012, the Rwandan authorities inspected 84 structures that were found not to meet safety standards. The following year there were as many as 120 . Investigations showed that the electrical installations in the facilities in question did not meet safety standards and often were outdated or incorrectly installed. It should be emphasized that local construction companies are not able to compete with the Chinese.

Most of the large construction and infrastructure projects are carried out by Chinese contractors. Chinese companies win large tenders due to the combination of low construction costs with huge technical and financial possibilities. They offer low prices because they import most of their materials and equipment from their Chinese partners, who supply them with the materials at low prices. For example, in a government tender for constructing a hangar at the international airport in Kigali, China Star won the bidding for \$1.2 million. Two other local firms: Real Constructors Ltd and Horizon Construction, a subsidiary of the Horizon Group, submitted bids of $\$ 1.8$ million and $\$ 3$ million, respectively ${ }^{14}$. Chinese construction companies are sometimes accused of abuses in tender procedures. The reduced value of a project is often the result of cost reductions that affect the quality of the projects ${ }^{15}$.

14 D. Nzohabonimana, op.cit.

15 Ibidem. 
In downtown Kigali, Chinese labor is used to build shopping malls and hotels. The Kigali Marriot Hotel is one of the projects awarded to Chinese contractors. In March 2011, the American hotel chain signed a partnership agreement with the Rwandan government and the New Century Development Limited corporation from China responsible for the construction of the hotel. Most materials for the construction were imported from China, except for Ugandan cement and a few local materials such as wood and bricks, which are cheap and would be expensive to transport from China ${ }^{16}$.

It is difficult to compete with Chinese companies that gain access to cheap capital. Their financial capacity comes from their parent banks, which provide them with loans at very low-interest rates. Wei Heng, COO of China Star Construction Co. Ltd, said his company has access to Chinese banks that offer loans at $8 \%$ interest rates. Local Rwandan companies have to go to great lengths to get loans, and when they do, they have high-interest rates that range from 17 to $18 \%{ }^{17}$. It is also difficult to supervise Chinese corporations to adhere to the bidding conditions as they often use substandard materials that were not specified in the bidding conditions to maximize profits. Despite much controversy, Africans, and especially Rwandans, are willing to cooperate with the Chinese in the agricultural development sector ${ }^{18}$. Following the 2007-2008 food price crisis, food system scientists speculated that China was taking land overseas to secure food resources for the future. The argument has been made that China is trying to seize land in Africa to force food

\footnotetext{
16 Ibidem.

17 Ibidem.

18 Ł. Firmanty, op.cit., p. 151.
} 
production. In turn, the Chinese use the aid granted in agriculture to enter African agricultural sectors and thus want to gain preferential access to local markets for agricultural production $^{19}$.

African countries, including Rwanda and Uganda, are interested in building agricultural partnerships with China. Isaac Lawther said these countries are trying to work with China because China offers agricultural technologies that enable these countries to implement their national agricultural development plans. The Chinese offer cheap agricultural machinery, easy to use, and much more economical to operate than those from the West. The technology is adapted to local needs. For example, harvesters bought in Europe and the United States are expensive, equipped with modern technologies that create problems for the local population during use, and they burn hundreds of liters of fuel. Moreover, Chinese agricultural and animal husbandry technologies are closer to local lifestyles. For example, fish farming in China is associated with the local tradition of breeding this type close to Rwandan. So China proposes technologies suitable for Rwandan rural areas ${ }^{20}$.

Another problem is the accusation of Western countries that Beijing is trying to make African countries dependent on their increasing debts for infrastructure projects and loans granted by the Chinese. According to Beijing, these allegations are unfounded. China is in danger of losing its lending due to the impoverishment of many African countries that have to resist trade tariffs, restrictions, and bans of various

19 I. Lawther, Why African countries are interested in building agricultural partnerships with China: lessons from Rwanda and Uganda, “Third World Quarterly" 2017, vol. 38, no. 10, pp. 1-18.

20 Ibidem. 
kinds imposed by the United States and its allies. Chinese corporations are helping to strengthen trade routes in developing parts of the world. It is in the interest of the Middle Kingdom to maintain balanced and stable growth in Africa ${ }^{21}$. Supporting the development of trade routes and delivery methods in developing parts of the world is mutually beneficial.

Chinese aid is mainly focused on infrastructure projects. On the other hand, the West is generally reluctant to help finance infrastructure, despite the country's urgent needs to do so. What is more, the Middle Kingdom offered help without setting the conditions typical for Western countries, such as improving the state of respecting human rights, building a strong economic system, implementing an environmentally friendly policy, etc. in the United Nations (UN) and the United Nations Security Council (UNSC). The Chinese ambassador to Rwanda, Shu Zhan, said: "You give a man a fish, and you feed him for a day. You will teach him to fish, and you will feed him for life". Rwandans strongly believe that their homeland, thanks to foreign aid and foreign investors, will soon overcome the poverty barriers and become a highly developed country ${ }^{22}$. Paul Kagame stated that the Chinese bring what Africa needs: investment and money for governments and companies. The president said: "I would prefer the Western world to invest in Africa rather than give development aid. Help is needed - but it should be implemented in such a way as to enable trade and build businesses. High trade tariffs prevented African producers

21 China must allay any debt-trap fears in its dealings with Africa, https://www.scmp.com/comment/opinion/article/3017478/china-mustallay-any-debt-trap-fears-its-dealings-africa [access: 05.01.2020].

22 China praised for African links, http://news.bbc.co.uk/2/hi/africa/8301826.stm [access 13.11.2019]. 
from gaining fair access to world markets. It would help Africa much more if the industrialized countries allowed us to have the same trade rights they give each other ${ }^{23}$.

Rwanda sets itself China as a model of economic development. It is a model that prioritizes stability and economic growth over personal and social freedoms. Rugaba Silas, Rwanda's ambassador to China, announced in 1995 that Rwanda was seeking to learn from Chinese experiences in overcoming the difficult past of years of civil war, hunger, poverty, and fanatical cultural revolution. In practice, Rwanda has adopted some questionable practices that could also be seen in China. The Rwandan government is accused of ignoring human rights and ending poverty, not its roots. China's involvement in Rwanda is based on non-interference in political matters and focuses on the mutual benefits that both countries can obtain from trade, investment, and economic cooperation ${ }^{24}$. Mainly due to the principle of non-interference in the internal affairs of African states, China is accused of disregarding violations of human rights and democratic principles and supporting authoritarian regimes. Rwanda's economic cooperation with China is mutually beneficial ${ }^{25}$. The Rwandan society highly appreciates the effects of cooperation in the agricultural and fisheries sectors, the technologies introduced, and thus the quality of products and their prices. On the other hand, Rwandans are a bit concerned about the quality of goods imported directly

23 Zambian economist Dambisa Moyo shares Paul Kagame's opinion criticizing Western help for Africa. D. Moyo, Dead Aid. Why Aid is Not Working and How there is another way for Africa, New York 2010, pp. 29-47, China praised for African links, http://news.bbc.co.uk/2/hi/ africa/8301826.stm [access 13.11.2019].

24 J. Gu, A. Carty, op.cit., pp. 57-69.

25 Ibidem. 
from China, as opposed to those exported from Japan ${ }^{26}$.

The country's economic development is a priority for the Rwandan government. In 2016, Rwanda was considered one of the fastest-growing economies on the continent and wanted to be considered Africa's business and technology center. Through investments, she hopes to move away from foreign aid, which in 2016 accounted for almost 40\% of its annual budget ${ }^{27}$. The long-term development path for Rwanda, its economic and economic goals until 2020 are defined in the document "Rwanda Vision 2020" prepared by the Ministry of Finance and Economic Planning of Rwan$\mathrm{da}^{28}$. The plan sets out a development framework for Rwanda, outlining the priority directions for development for the state. As a result of the research conducted in Rwanda in December 2018, conversations with representatives of the local administration, and observations of everyday life in this country, the author of this article formulates the following opinion. Well, regardless of the conflicting assessments of analysts and scientists as to economic development and ways of managing the state, compared to neighboring countries, the government in Kigali can ensure and maintain border security, and society is evolving to create a strong and united nation, proud of its achievements and respecting basic social values.

26 V. Byusa, op.cit., pp. 66-83.

27 L. Kuo, op.cit.; Ministry of Foreign Affairs and International Cooperation, https://www.minaffet.gov.rw/index.php?id=12 [access: 19.08.2019].

28 Government file issued by Rwandan Ministry of Finance and Economic Planning. D. Karebuka, Rwanda Vision 2020, „Republic of Rwanda. Ministry of Finance and Economic Planning”, Kigali 2000, pp. 1-31, https://www.sida.se/globalassets/global/countries-and-regions/africa/ rwanda/d402331a.pdf [access: 14.11.2019]. 


\section{Bibliography}

Bar J., Po ludobójstwie: państwo i społeczeństwo w Rwandzie 1994-2012, Kraków 2013.

Bar J., Rwanda, Warsaw 2013.

Byusa V., Chinese external assistance to Rwanda, "NUR Rwanda Journal" 2010, vol. 19, series B.

Chretien J.-P., The Great Lakes of Africa. Two thousand years of History, New York 2006.

Firmanty Ł., Afryka we wspótczesnej polityce Chińskiej Republiki Ludowej, Toruń 2013.

Jing G., Carty A., China and African Development: Partnership not Mentoring, Institute of Development Studies" 2014, vol. 45, no. 4 .

Karebuka D., Rwanda Vision 2020, „Republic of Rwanda. Ministry of Finance and Economic Planning”, Kigali 2000. Lawther I., Why African countries are interested in building agricultural partnerships with China: lessons from Rwanda and Uganda, "Third World Quarterly" 2017, vol. 38 , no. 10 .

Moyo D., Dead Aid. Why Aid is Not Working and How there is another way for Africa, New York 2010.

N’Diaye T., Żótte i czarne: historia chińskiej obecności w Afryce, Warsaw 2016.

Nanda K., New 'Friends' of Rwanda - Chinese Noodles and Indian Curry: An Analysis of Asian Giants' Forays into Rwanda in the Light of Theories on OFDI, [in:] Rwanda Fast Forward, eds. M. Campioni et al., London 2012.

The Diplomatic Magazine. Minaffet Ministry of Foreign Affairs and Cooperation, Ministry of Foreign Affairs and International Cooperation, Kigali 2009. 


\title{
Websites
}

www.minaffet.gov.rw.

www.paulkagame.com.

www.pambazuka.org.

www.therwandan.com.

www.sida.se.

www.msn.com.

www.scmp.com.

www.news.bbc.co.uk.

www.qz.com/africa.

\begin{abstract}
The renascence of Asia and the growth of the importance of developing countries is one of the most important changes in contemporary international relations. Today, China is changing the geopolitical balance of power. The Middle Kingdom they have become a strong international player and rival to the US and the EU. In the 1990s, China began to increase its presence in sub-Saharan Africa systematically. Diplomatic relations between the People's Republic of China and Rwanda were established on November 12, 1971. Today, China is one of Rwanda's most important economic and political partners.
\end{abstract}

Keywords: Africa, China, Rwanda, cooperation

\begin{abstract}
Abstrakt
Odrodzenie Azji, a także szybki wzrost znaczenia państw rozwijających się stanowi jedną z najistotniejszych zmian w systemie współczesnych relacji międzynarodowych. Współcześnie to Chiny zmieniają geopolityczną równowagę sił. Państwo Środka stało się silnym graczem międzynarodowym i rywalem dla USA i UE. W latach 90-tych XX wieku Chiny zaczęły systematycznie
\end{abstract}


zwiększać swoją obecność w Afryce Subsaharyjskiej. Stosunki dyplomatyczne między Chińską Republiką Ludową a Rwandą nawiązano 12 listopada 1971 roku. Współcześnie Chiny są jednym z najważniejszych partnerów gospodarczo-politycznych Rwandy.

Słowa kluczowe: Afryka, Chiny, Rwanda, współpraca 


\section{Zuzanna Sielska}

University of Silesia

ORCID ID: https://orcid.org/0000-0003-1885-0313

\section{Balkan Game - Contemporary Relations of Serbia with Selected International Entities (Russia, USA, European Union, China)}

\section{Introduction}

The Western Balkans is a region of interest to various international actors today. This area occupies an important place in the European Union's strategy for peace and regional development. However, it is also important for the North Atlantic Pact, Russia, or the current economic policy of China in Central and Eastern Europe. Serbia is the most rapidly developing country in the Western Balkans. Although the country is facing many challenges, it is trying to reconcile its relations with the European Union, the USA, Russia, and China.

The chapter presents current problems and challenges regarding Serbia's relations with selected international entities. Initially, the socio-economic situation in the country is outlined based on reports from 2020, including World Bank, Transparency International, Freedom House, World Happiness. Then, Serbia's relations with Russia, the United States, the European Union, and China is presented. In addition, the text deals with the important subject of the currently 
conducted "vaccine diplomacy", that is, relations between countries determined by the current situation in the world.

\section{Socio-Economic Situation in Serbia}

Serbia is a country located in the south-eastern part of Europe on the Balkan Peninsula, has an area of $88361 \mathrm{~km}^{2}$, and is inhabited by 7186862 people ${ }^{1}$. Serbia is divided into 17 counties, an autonomous province - Vojvodina, and the controversial area of Kosovo. As a result of the conflict, the territory of Kosovo declared independence on February 17, 2008, but Serbia does not recognize this act of secession. The beginning of Serbia's statehood is the 11th century, then in the $12^{\text {th }}$ and $13^{\text {th }}$ centuries, the great Nemanjiciów state was created, to which the rulers in modern Serbia refer. After centuries of glory, the Ottoman Turks ruled the Serbian state for over five hundred years. After the First World War, these lands became part of the Duchy and then the Kingdom of Serbs, Croats, and Slovenes, ruled by the Serbian Karaborđevic dynasty. Subsequently, Serbia was one of the six former republics of Yugoslavia that included the capital of the "Titov" entity.

This country belongs to many international organizations, such as the United Nations or the Organization for Security and Cooperation in Europe. Serbia is also a member of the Cooperation between China and Central and Eastern European Countries $-17+1$ initiative and plays a strategic role in many of China's investments and the One Belt - One Road project in Europe. Since 2018, Serbia has

1 Republički zavod za statistiku, popis 2011, https://www.stat.gov.rs/ sr-latn/oblasti/popis/popis-2011/ [access: 25.12.2020]. 
recorded stable economic growth, a significant drop in unemployment, and reduced its public debt. According to the data of the Serbian statistical office from 2019, the Gross Domestic Product was $\$ 7.411$ per capita ${ }^{2}$ compared to the previous year. In addition, the unemployment rate was dropping year by year, and at the end of 2019, it amounted to $9.5 \%{ }^{3}$, which is the lowest result among the Western Balkan countries.

Family is an important source of financial and emotional support for young people in Serbia ${ }^{4}$. Young people often live with their parents until late into adulthood. Relatively low earnings favor it because the average net monthly earnings were EUR 507 in 20195. Moreover, it is common among young people to want to leave the country. Although the main reason for emigration is the desire for a better life, the intensity of this desire is more related to the pessimistic view of the future of Serbian society ${ }^{6}$. According to the European Statistical Office data, more than 4,000 people leave Serbia each month, and 51,000 every year, mainly young people?

2 GDP per capita - Serbia, World Bank, https://data.worldbank.org/ indicator/NY.GDP.PCAP.CD? locations=RS [access: 2.02.2021].

3 Stopa nezaposlenosti u Srbiji 9,5 odsto, N1, http://rs.n1info.com/ Biznis/a548078/RZS-Stopa-nezaposlenosti-u-Srbiji-9-5-odsto.html [access: 27.12.2020].

4 D. Popadić, Z. Pavlović, S. Mihailović, Mladi u Srbiji 2018/2019, Friedrich-Ebert-Stiftung 2019, p. 6, https://www.researchgate.net/publication/333185709_Mladi_u_Srbiji_20182019 [access: 27.12.2020].

5 List of European countries by average wage, https://en.wikipedia.org/wiki/List_of_European_countries_by_average_wage [access: 2.02.2021].

6 D. Popadić op.cit., p. 6.

7 Vesti, N1, http://rs.n1info.com/Vesti/a524373/Srbiju-mesecno-napusti-vise-od-4.000-ljudi.html [access: 27.12.2020]. 
According to the World Happiness Report, Serbia ranks 63 among 153 countries in the world in the happiness ranking $^{8}$. Among the former republics of Yugoslavia, it ranks second after Slovenia (33rd place in the ranking). Serbia, however, faces many problems. Firstly, there is a corruption problem in the state. According to the Transparency International report, Serbia ranks 91st out of 180 countries $^{9}$.

Additionally, the problem is the rule of law, which is the most difficult point to negotiate with the European Union. EU representatives believe that Serbia has failed to implement the necessary reforms in this area. In 2020, for the first time since 2003, Serbia was classified as only half-democratic in the Freedom House report. Serbia scored 66 points out of $100^{10}$. The reason is the current rule of President Aleksander Vučić, the leader of the Serbian Progressive Party, who is accused of total control of the media in the country. Anti-government protests in Serbia have been going on since 2018. However, it is worth mentioning that no country in the Western Balkans has been entirely democratic. The issue that affects Serbian relations with states in the international arena and the internal political situation is recognizing the statehood of Serbia's former autonomous province - Kosovo ${ }^{11}$. Events such as the conflict in the region and the NATO bombing of Yugoslavia in 1999, and the consequent

8 World Happiness report 2020, https://worldhappiness.report/ ed/2020/social-environments-for-world-happiness/ [access: 24.11.2020].

9 Transparency International, https://www.transparency.org/en/ countries/serbia\# [access: 29.12.2020].

10 Freedom house, Serbia, https://freedomhouse.org/country/serbia/ freedom-world/2020 [access: 29.12.2020].

11 Z. Sielska, Bitwa na Kosowym Polu jako mit ksztattujacy tożsamość serbska, [in:] Poetyki czasu, miejsca i pamięci, eds. W. Olkusz, B. Szymczak-Maciejczyk, vol. XI, Wrocław 2020, pp. 155-190. 
break-up of Yugoslavia, determine Serbia's present position and the condition of its society.

\section{The US, Russia, the European Union, and China - Western and Eastern Impact on Serbia}

Russia. The relations between Serbia and Russia are determined by their common history, and the religious and cultural community. Wherefore, Russia played a significant role in the war after the dissolution of Yugoslavia. On the one hand, Boris Yeltsin wanted to rebuild and strengthen good relations with the West, but on the other hand, he was under intense pressure from the popular Pan-Slavic idea. Undoubtedly, Russia was the strongest and most important ally of Serbs in Bosna and Herzegovina. In 1994 and 1995, strongly condemned NATO's actions also opposed implementing a resolution filed by Muslim countries, banning fuel from Serbia for the Serbian and Croatian forces ${ }^{12}$. At the end of the war, Russia contributed to the proposals for the peace treaty being prepared and the participation of Russian soldiers in the IFOR (Implementation Force). In 1995 there were likewise talks between Bill Clinton and Boris Yeltsin on the end of the conflict and the future shape of Bosnia and Herzegovina. Russia was in opposition to the United States, which supported the Muslims in Bosnia and the Albanians in Kosovo during the Balkan war.

However, the most important matter was Russia's opposition to NATO's attack on Serbia in 1999. The Serbs remember this gesture of solidarity, and although they are

12 T. Gazzini, NATO Coercive Military Activities in the Yugoslav Crisis (1992-1999), http://ejil.org/pdfs/12/3/1526.pdf [access: 28.04.2021]. 
trying to join the European Union now, they stress the reluctance to join NATO. Then, Aleksandar Vučić admitted that Serbia would not join the bloc's sanctions on Moscow and said: "Serbia will continue to pursue its own policies and we expect to get understanding from the EU, if not Serbia is an independent and free country". It was said after the meeting with Russian Foreign Minister Sergei Lavrov in Belgrade $^{13}$. The best example of Serbian and Russian friendship was occurrence in January 2019. More than 100,000 people welcomed Vladimir Putin during his visit to Belgrade to support his politics on the Balkan peninsula. Putin was throwing his weight behind Serbia in the dispute over Kosovo in his speech. In Belgrade, he fired criticism at Kosovar Albanians for establishing an army last year. Serbia's President Aleksandar Vučić and Putin discussed the routing of TurkStream2, a gas pipeline linking Russia and the EU, through Serbia. Gazprom is ready to invest $\$ 1.4 \mathrm{bn}$ in the venture. As a result, in February 2020, the Serbian energy regulator approved Gastrans, formerly South Stream Serbia, as an "independent" gas grid operator. Most importantly, Russian Gazprom holds a 51\% stake in the company, with the state-owned Srbijagas holding the remaining $49 \%{ }^{14}$.

Not only political and diplomatic relations are important for these two countries, but also military affinities. In December 2016, Serbia and Russia signed a military-technical assistance agreement that allowed Serbia to receive

13 G. Filipvić, M. Savic, Eu Membership Won't Change Serbian Russian Ties, Vucic says, Bloomberg, https://www.bloomberg.com/news/ articles/2018-08-17/draghi-s-richer-toolbox-keeps-ecb-calm-as-turkeyand-italy-rage [access: 27.04.2021].

14 S. Bieniek, Russia's economic soft power: The case of Serbia, “Rocznik Instytutu Europy Środkowo-Wschodniej” 2020, vol. 18, no. 3, pp. 93-114. 
the following as a gift: six Mikoyan MiG 29, six fighters, 30 modernized T-72 main battle tanks, and 30 BMP-2 infantry fighting vehicles. Common fights and exercises were delivered in October $2017^{15}$. Although it does not support Serbia financially as much as the European Union, Russia is still a desirable partner for this country. It is one of the few countries that openly support Serbia in its conflict with Kosovo, which is important not only for the rulers but also for most people.

During the COVID-19 pandemic that began in 2020, Serbia received approximately 300,000 doses of vaccines from Russia. The President of Serbia did not hide his gratitude to Vladimir Putin: "Our Russian friends respected everything we agreed on and did everything on time. This is great support, great gratitude to Russia, and I would like to express my special thanks to President (of Russia), Vladimir Putin"16, said A. Vučić. Russia planned to deliver about 2 million doses of vaccines.

United States of America. The United States is also an important player in the Western Balkans. During the Cold War, the US was not interested in influencing the Balkan Peninsula. Soon after Josip Broz Tito withdrew from USSR politics, the US began to maintain proper relations with Yugoslavia. However, the event that significantly influenced relations with Serbia was the civil war in the 1990s, especially the interference in the Serb-Kosovar conflict. After all, following unsuccessful negotiations of the contract group,

15 M. Zivanović, Russia Military Deal Deemed 'Good Thing' For Serbia, Balkan Insight, http://www.balkaninsight.com/en/article/new-serbian-russian-military-deal-good-thing--04-04-2018 [access: 27.04.2021].

16 U Srbiju stiglo još 100 hiljada Sputnik V vakcina, dočekali ih Vučić i ruski ambasador, Radio Slobodna Evropa, https://www.slobodnaevropa. org/a/31127051.html [access: 26.04.2021]. 
on March 24, 1999, NATO forces began military operations without a declaration of war, undertaking Operation Allied Force. Yugoslavia (today's Serbia, Montenegro, and Kosovo) was bombed by NATO peacekeepers until June 10, 1999. The Serbian government severed diplomatic relations with the US, Great Britain, Germany, France, and Albania. Ultimately, after a successful operation and negotiations, peace was achieved. Kosovo declared independence on February 17, 2008, and was recognized by most UN states. Among others, Spain, Romania, Cyprus, Greece, Slovakia, Russia, Israel, and China did not recognize it. The demonstrating Serbs expressed their objection by setting fire to the US Embassy in Belgrade. For the demonstrating Serbs, the US and its interests led to the secession of part of Serbia.

According to many experts, Operation Allied Force was inconsistent with international law. Referring primarily to the law of war (ius in bello), which prohibits the use of force as a method of conflict resolution (the principle of nonintervention), they argue that military operations and the bombing of Yugoslavia were illegal under international law. During the bombings, many international organizations and some NATO members (Italy, Greece) expressed their opposition to the use of military force.

The conflict over Kosovo continues to exist in Serbian internal and external politics. The Kosovo issue determines its relations with other international actors. Serbia has not yet recognized Kosovo's independence (as of 2021). The conflict also affects Serbia's social condition. The Serbs still cannot come to terms with the loss of land. Currently, negotiations are underway between Serbia and Kosovo, also by the United States, which in March 2020 negotiated the withdrawal of $100 \%$ of the duty imposed on Serbian products by Kosovo. 
In addition, an agreement between Serbia, the United States, and Kosovo was signed on September 4, 2020. The deal was hailed as a success by Donald Trump, especially since it was signed at the end of the US president's term of office.

Despite the announcement of a historic improvement in relations between the conflicting states, the agreement did not settle the most contentious issue, namely the recognition by Serbia of Kosovo's independence and sovereignty. The Trump agreement primarily regulated economic, border, and infrastructural relations between Serbia and Kosovo. Among others: an agreement on the construction of railway and road connections Belgrade-Pristina and other infrastructural and economic projects linking the two countries. It was also declared to open a common border point in Merdare, and Kosovo to join the Balkan mini-Schengen. Intensification of the search for people missing during the conflict in 1998-1999 and the regulation of the lake in Serbia and Kosovo (Serbian - Gazivoda, Albanian - Ujman). In addition, controversial points in the copy for Serbia, including a ban on the supply of $5 \mathrm{G}$ equipment from untrusted suppliers (thus hitting Huawei and Serbian-Chinese relations) and the Serbian Embassy's transfer from Tel-Aviv to Jerusalem ${ }^{17}$. Although the signing of the agreement in Washington was a media event reported worldwide, it did not have much significance for the complicated Serb-Kosovar relations.

European Union. Nonetheless, Moscow and Washington do not provide financial assistance, such as loans for infrastructure development, unlike the European Union. In

17 Z. Sielska, Podsumowanie 2020 roku. Serbia, blog Forum Młodych Dyplomatów, http://diplomacy.pl/pl/blog/europa-wschodnia/item/ 542-podsumowanie-2020-roku-serbia [access: 4.04.2021]. 
2016, the deputy head of the EU Delegation to Serbia, Oskar Benedikt, said the EU is the "main investor" in Serbia with a share of $82 \%$ of net foreign investments, and by the past 15 years, investments from the EU amounted to 15 billion euros $^{18}$. Generally, the EU is the Western Balkans' largest trading partner. Trade with the European Union represents $72.8 \%$ of the total trade flows of the region ${ }^{19}$. For the European Union, the territory of the Balkan Peninsula has always been important. Admittedly, the EU has failed to develop a policy regarding the conflict after the break-up of Yugoslavia. However, from the beginning, one of the aims was to maintain peace in the region. The Union also finances political and economic stabilization. It implements many programmes consisting of the delegation from the Member States of advisers and experts who train administrative officials, business associations, courts, and parliaments ${ }^{20}$.

In 2012, Serbia started accession talks with the European Union. Integration with the European Union has great support because, according to the Ministry of European Integration of Serbia, over $50 \%$ of the inhabitants of this country support joining the structures of this organization ${ }^{21}$. However, the increase in Eurosceptics in Serbia in 2019 com-

18 Koliko je novca Evropska unija zaista dala Srbii - rezultati su neverovatni, Telegraf.rs, https://www.telegraf.rs/vesti/2517092-kolikoje-novca-evropska-unija-zaista-dala-srbiji-rezultati-su-neverovatni-foto [access: 15.10.2018].

19 European Commission, EU-Western Balkans, Economic Relations - investing in People, Infrastructures and Reforms May 2018, https:// ec.europa.eu/commission/sites/beta-political/files/economic-relations_ en.pdf [access: 15.10.2018].

20 N. Lubik-Reczek, Państwa Postjugosłowiańskie wobec członkostwa w Unii Europejskiej i NATO, Toruń 2011, pp. 98-99, 113.

21 Istinomer, https://www.istinomer.rs/izjava/izjednacen-broj-gradjana-koji-su-za-eu-i-protiv-nje/ [access: 8.02.2021]. 
pared to 2018 may seem worrying 22 . However, supporters of European integration still predominate. Currently, one of the issues determining relations between Serbia and the European Union is the recognition of Kosovo's independence. Both Kosovo and Serbia apply for membership of the European Union, but the condition is the normalization of relations between the states. Since 2013, the significance of this issue has been confirmed by studies conducted by the Center for Social Dialogue and Regional Initiative (Centar za društveni dijalog i regional inicijative / CDDR) in September $2019^{23}$. In the survey, $65 \%$ of respondents stated that recognizing Kosovo is a condition for Serbia's membership in the European Union. However, as many as $71 \%$ of citizens would not support a possible government decision to recognize Kosovo in return for belonging to the EU structures ${ }^{24}$.

Although the European Union did not provide Serbia with vaccines, already in March 2020, it allocated EUR 7.5 million for direct aid with the pandemic ${ }^{25}$. In addition, at the beginning of 2021, the European Union decided to assist in the amount of EUR 70 million under the Instrument for Pre-Accession Assistance for quick access to vaccines in the Western Balkans ${ }^{26}$.

22 Balkan Barometer, [in:] Mapping Fake News and Disinformation in the Western Balkans and Identifying Ways to Effectively Counter Them, European Parliament 2020, p. 35, https://www.europarl.europa.eu/RegData/etudes/STUD/2020/653621/EXPO_STU(2020)653621_EN.pdf [access: 29.12.2020].

23 CBS Crno-Beli Svet, Istraživanje CDDRI, http://crnobelisvet. com/preko-sedamdeset-odsto-bi-prizanje-kosova-videlo-kao-izdaju-zso-i-stolica-u-un-prihvatljiv-scenario/ [access: 30.10.2020].

24 Ibidem.

25 B. Kowalski, Chiny-Serbia-UE: wojna na narracje wokót epidemii koronawirusa, http://osa.uni.lodz.pl/?p=10886 [access: 26.04.2021].

26 Live work travel, corona virus response, https://ec.europa.eu/info/ 
China. The Middle Kingdom is currently one of the largest economies in the world. After years of marginalization, China has opened to the reforms considered by Deng Xiaoping the most important to the state. China has experienced incredible economic growth in recent 30 years. Every year, the Chinese GDP increases by 10\%. In 2012, China was already in second place in the world ${ }^{27}$. However, as has been mentioned many times, China needs partners, commercial outlets, and investment opportunities. Therefore, they focus on "conquering" other markets ${ }^{28}$. In April this year, another meeting was held in Beijing as part of the One Belt, One Road - OBOR initiative. The concept presented at the end of 2013 by the President of the PRC Xi Jinping, the idea of OBOR, which consists of the land part ("economic belt of the silk route") and the sea part ("the sea silk route of the $21^{\text {st }}$ century"). on the creation of new transport networks (road, rail - including high-speed rail - sea and transmission) between China and the most important trade partner of China - the European Union, as well as the countries of the Middle East, Africa and Central Asia and the Balkans.

China is not interested in "imposing" its model on others in any overt sense but invests in high-visibility infrastructure, like motorways and railways, as well as cultural and language centers instead. China is primarily concerned with completing its "New Silk Road" project, also known as the "One Belt, One Road" Initiative ${ }^{29}$, wherefore is interested in

live-work-travel-eu/coronavirus-response/timeline-eu-action_pl [access: 21.04.2021].

27 J. Sielski, Perspektywy przywództwa w Azji, "Nowa Polityka Wschodnia” 2014, vol. 2, no. 7, pp. 20-21.

28 J. Bartosiak, Pacyfik i Euroazja, O wojnie, Warsaw 2016, p. 313.

29 P. Tonchev, China's Road: Into the Western Balkans, "European Union Institute for Security Studies Brief” 2017, no. 32017, https://www. 
improving the basic infrastructure of the Balkans, which is considered a future entry point into Europe proper for its economics products ${ }^{30}$. Plans for the project seem to be serious. In 2014, China set up a $\$ 40$ billion Silk Road fund. In 2015, it launched a $\$ 20$ billion Energy Development Fund (to finance the New Silk Road) and started the Railway Line expansion $^{31}$. According to statistics, between 2005 and 2015, EUR 125 million of Chinese direct investment affluence to Serbia, 82 million in 2014. Relations with Serbia are important mainly due to the plan to form the southern branch of the New Silk Road through the project of building a transport corridor between the Greek port of Piraeus and Central Europe $^{32}$.

Furthermore, in 2014, the second bridge over the Danube in Belgrade, worth 170 million euros, was completed. The investment was financed mainly by a China Exim Bank loan. In 2016, the Chinese company He Steel Group took over the largest Serbian ironworks Železara Smederevo, which cost was EUR 46 million. In November 2017, it started building a new power unit at the $350 \mathrm{MW}$ power plant in Kostolac. The project worth around EUR 600 million is carried out by China Machinery Engineering Corporation (CMEC), and $80 \%$ of its costs are to be covered by China Exim Bank. Besides, investments such as the modernization of the 35-kilometer stretch of the Belgrade-Sara Pazov

iss.europa.eu/sites/default/files/EUISSFiles/Brief\%203\%20China\%27s\%20 Silk\%20Road.pdf.

30 L. Poulain, China's New Balkan Strategy, "Center for Strategic and International Studies - Central Europe Watch” 2011, vol. 1, no. 2.

31 J. Bartosiak, op.cit., pp. 350-351.

32 J. Jakóbowski, Xi Jinping in Serbia: not just the economy, Ośrodek Studiów Wschodnich, https://www.osw.waw.pl/en/publikacje/analyses/2016-06-22/xi-jinping-serbia-not-just-economy [access: 22.06.2016]. 
connection are planned in the future. They are to be held by China Railways International and China Communications Construction Company, and the total cost is 350 million $\mathrm{USD}^{33}$. According to the local media, China is building one of the largest Chinese cultural centers in the world in Belgrade, with a hundred-year plan for cultural exchange with and activities within Serbia and the region ${ }^{34}$. At the turn of 2019 and 2020, work began on the Borča industrial park, worth EUR 220 million, becoming the largest project of this type in Eastern Europe ${ }^{35}$.

In addition to economic cooperation, the People's Republic of China also focused on soft power. Primarily, it manifests itself through collaboration in the field of culture, but also tourism. In 2019, Serbia was visited by 80,000 Chinese tourists ${ }^{36}$. Additionally, Serbia has a high number of students participating in numerous educational exchange programmes. China is also pursuing an effective policy because although their investments and loans are smaller than those of the European Union, they are rated best in terms of aid and influence in the region. Based on the National Bank of Serbia database, investments from China in 2019 for a total amount of EUR 321.8 million accounted for $8 \%$. Total foreign investment in Serbia is EUR 3.8 billion. However,

33 M. Szpala, Chiny wyręczają Unię Europejską na Bakanach Zachodnich, wnp.pl portal gospodarczy, https://www.wnp.pl/rynki-zagraniczne/chiny-wyreczaja-unie-europejska-na-balkanach-zachodnich,311981_1_0_0.html [access: 12.12.2017].

34 Kinezi grade veliki kuturni centar u Beogradu, N1 Srbija [access: 19.03.2017].

35 Industrial park in Borca, Inverst in see, http://www.investinsee. com/news/serbia/industrial-park-in-borca [access: 5.04.2021].

36 M. Janković, BBC, https://www.bbc.com/serbian/lat/srbija-46526531 [access: 28.04.2021]. 
in 2019 the EU invested EUR 3.2 billion in Serbia, which is almost $85 \%$ of all investments in Serbia in the previous year.

Nevertheless, it is Beijing that receives the most praise from Alexander Vučić. China is also looking to tighten military cooperation between the two countries. China has recently delivered unmanned aerial vehicles to Serbia ${ }^{37}$.

During the pandemic, Sino-Serbian relations were further strengthened. In 2020, on March 21, a plane with protective equipment and a group of 6 Chinese medical specialists landed in the Serbian capital. It was then that the President of Serbia thanked the Chinese authorities so much ${ }^{38}$. As early as January 2021, China supplied Serbia with one million doses of Sinopharm. In April, Serbia had 2.5 million doses of the vaccine from the PRC, making Serbia one of the most rapidly vaccinating countries for its citizens. The Belgrade authorities appreciate Beijing's help very much because China does not interfere in the policy pursued by President Alexander Vučić. At the last meeting, the President of Serbia stated that he "greatly appreciated China's consistent stance in respecting Serbia's territorial integrity and sovereignty" 39 .

37 Serbian president meets with Chinese defense minister, Chinadaily, http://www.chinadaily.com.cn/a/202103/27/WS605ee6eca31024adObab205f.html [access: 28.04.2021].

38 Vučić poljubio je kinesku zastavu i obećao slušati diplomaciju kako bi izbjegli 'katastrofalan talijanski scenarij, Direktno, https://direktno.hr/eu-i-svijet/vucic-poljubio-kinesku-zastavu-i-obecao-slusati-diplomaciju-kako-bi-izbjegli-katastrofalan-talijansk-189142/ [access: 28.04.2021].

39 Kineski ministar odbrane sa Vučićem u Beogradu, Radio Slobodna Evropa, https://www.slobodnaevropa.org/a/vucic-srbija-kina-ministar-odbrane/31171120.html [access: 27.04.2021]. 


\section{Summary}

Serbia is a rapidly developing country. Compared to other countries in the Western Balkans region, it is the best performer, both in terms of the minimum wage and the unemployment rate and GDP per capita. This country is also strategically located, as it lies on the so-called Balkan route connecting the Orient (Near East) with the Occident (European Union countries). That makes it attractive to many international entities, both politically and in terms of investment.

The European Union invests the most in Serbia. The country also benefits from many aid instruments (e.g., IPA) offered by the EU. However, the Balkan states are tired of meeting the conditions of the EU constantly, without concrete arrangements for the date of the new enlargement. On the other hand, the Balkans maneuver between joining NATO and maintaining good relations with Russia. In this case, China is gaining, having better and better relations with Serbia. It is because China is focused on strengthening economic ties and expanding the sales market but does not expect meeting democratic criteria, such as the European Union.

Currently, Serbia is at the center of the so-called "vaccine diplomacy". The European Union provided funding for vaccines from the COVAX programme. In addition, Serbia received vaccines from Russia and China (in Serbia, vaccines from Pfizer / BioNTech, AstraZeneca, Sinopharm, and the Russian preparation Sputnik V are used). Thanks to this supply and funding, Serbia has already vaccinated 1.32 mil- 
lion citizens and administered 3.27 million doses, which is $19 \%$ of the population vaccinated with the full dose ${ }^{40}$. Serbia has decided to pursue its own "vaccine policy" and deliver vaccines to Bosnia and Herzegovina, North Macedonia, Montenegro and organize vaccinations for Serbs living in Kosovo. In addition, vaccine tourism is flourishing in Serbia, as foreigners can register in the system and get vaccinated in this country. However, they only have the AstraZeneca vaccine to choose from ${ }^{41}$.

\section{Bibliography}

Balkan Barometer, [in:] Mapping Fake News and Disinformation in the Western Balkans and Identifying Ways to Effectively Counter Them, European Parliament 2020, https://www. europarl.europa.eu/RegData/etudes/ STUD/2020/653621/EXPO_STU(2020)653621_EN.pdf. Bartosiak J., Pacyfik i Euroazja, O wojnie, Warsaw 2016. Bieniek S., Russia's economic soft power: The case of Serbia, „Rocznik Instytutu Europy Środkowo-Wschodniej” 2020, vol. 18 , no. 3 .

CBS Crno-Beli Svet, Istraživanje CDDRI (2019), http:// crnobelisvet.com/preko-sedamdeset-odsto-bi-prizanjekosova-videlo-kao-izdaju-zso-i-stolica-u-un-prihvatljivscenario/.

40 Coronavirus (COVID-19) Vaccinations, Our World in Data, https://ourworldindata.org/covid-vaccinations?country=OWID_WRL [access: 28.04.202]).

41 Serbia jako pierwsza w Europie zaczęła szczepienia migrantów, gazetaprawna.pl, https://www.gazetaprawna.pl/wiadomosci/swiat/artykuly/8129821,koronawirus-szczepienia-migrantow-w-obozach-serbia. html [access: 27.04.2021]. 
Coronavirus (COVID-19) Vaccinations, Our World in Data, https://ourworldindata.org/covid-vaccinations? country=OWID_WRL.

European Commission, EU-Western Balkans, Economic Relations - investing in People, Infrastructures and Reforms May 2018, https://ec.europa.eu/commission/sites/betapolitical/files/economic-relations_en.pdf.

Filipvić G., Savic M., Eu Membership Won't Change Serbian - Russian Ties, Vucic says, Bloomberg, https://www. bloomberg.com/news/articles/2018-08-17/draghi-sricher-toolbox-keeps-ecb-calm-as-turkey-and-italy-rage. Freedom house, Serbia, https://freedomhouse.org/country/ serbia/freedom-world/2020.

Gazzini T., NATO Coercive Military Activities in the Yugoslav Crisis (1992-1999), http://ejil.org/pdfs/12/3/1526. pdf.

GDP per capita - Serbia, World Bank, https://data.worldbank.org/indicator/NY.GDP.PCAP.CD? locations=RS.

Industrial park in Borca, Inverst in see, http://www.investinsee.com/news/serbia/industrial-park-in-borca.

Istinomer, https://www.istinomer.rs/izjava/izjednacen-brojgradjana-koji-su-za-eu-i-protiv-nje/.

Jakóbowski J., Xi Jinping in Serbia: not just the economy, Ośrodek Studiów Wschodnich, https://www.osw.waw. $\mathrm{pl} /$ en/publikacje/analyses/2016-06-22/xi-jinping-serbianot-just-economy.

Janković M., BBC, https://www.bbc.com/serbian/lat/srbija-46526531.

Kowalski B., Chiny-Serbia-UE: wojna na narracje wokót epidemii koronawirusa, Ośrodek Spraw Azjatyckich Uniwersytet Łódzki, http://osa.uni.lodz.pl/?p=10886.

List of European countries by average wage, https://en.wiki 
pedia.org/wiki/List_of_European_countries_by_average_wage.

Live work travel, corona virus response, Europa.eu, https:// ec.europa.eu/info/live-work-travel-eu/coronavirus-response/timeline-eu-action_pl.

Lubik-Reczek N., Państwa Postjugostowiańskie wobec członkostwa w Unii Europejskiej i NATO, Torun 2011. Popadić D., Pavlović Z., Mihailović S., Mladi u Srbiji 2018/2019, Friedrich-Ebert-Stiftung 2019, p. 6, https:// www.researchgate.net/publication/333185709_Mladi_u_ Srbiji_20182019.

Poulain L., China's New Balkan Strategy, Center for Strategic and International Studies - Central Europe Watch, 2011, vol. 1 , no. 2 .

Republički zavod za statistiku, popis 2011, https://www.stat. gov.rs/sr-latn/oblasti/popis/popis-2011/.

Serbia jako pierwsza w Europie zaczęła szczepienia migrantów, gazetaprawna.pl, https://www.gazetaprawna. $\mathrm{pl} /$ wiadomosci/swiat/artykuly/8129821, koronawirusszczepienia-migrantow-w-obozach-serbia.html.

Serbian president meets with Chinese defense minister, Chinadaily, http://www.chinadaily.com.cn/a/202103/27/ WS605ee6eca31024ad0bab205f.html.

Sielska Z., Bitwa na Kosowym Polu jako mit ksztattujacy tożsamość serbską, [in:] Poetyki czasu, miejsca i pamięci, eds. W. Olkusz, B. Szymczak-Maciejczyk, vol. XI, Wrocław 2020.

Sielska Z., Podsumowanie 2020 roku. Serbia, blog Forum Młodych Dyplomatów, http://diplomacy.pl/pl/blog/europa-wschodnia/item/542-podsumowanie-2020-roku-serbia. Sielski J., Perspektywy przywództwa w Azji, „Nowa polityka wschodnia" 2014, vol. 2, no. 7. 
Stopa nezaposlenosti u Srbiji 9,5 odsto, N1, http://rs.n1info. com/Biznis/a548078/RZS-Stopa-nezaposlenosti-u-Srbiji-9-5-odsto.html.

Szpala M., Chiny wyręczaja Unię Europejska na Bakanach Zachodnich, wnp.pl portal gospodarczy, https://www. wnp.pl/rynki-zagraniczne/chiny-wyreczaja-unie-europejska-na-balkanach-zachodnich,311981_1_0_0.html.

Kineski ministar odbrane sa Vučićem u Beogradu, Radio Slobodna Evropa, https://www.slobodnaevropa.org/a/vucicsrbija-kina-ministar-odbrane/31171120.html.

Kinezi grade veliki kuturni centar u Beogradu, N1 Srbija.

Koliko je novca Evropska unija zaista dala Srbii - rezultati su neverovatni, Telegraf.rs, https://www.telegraf.rs/ vesti/2517092-koliko-je-novca-evropska-unija-zaistadala-srbiji-rezultati-su-neverovatni-foto.

Tonchev P., China's Road: Into the Western Balkans, European Union Institute for Security Studies Brief, 2017, no. 3, https://www.iss.europa.eu/sites/default/files/EUISSFiles/ Brief\%203\%20China\%27s\%20Silk\%20Road.pdf.

Transparency International, https://www.transparency.org/ en/countries/serbia\#.

U Srbiju stiglo još 100 hiljada Sputnik V vakcina, dočekali ih Vučić i ruski ambasador, Radio Slobodna Evropa, https://www.slobodnaevropa.org/a/31127051.html.

Vesti, N1, http://rs.n1info.com/Vesti/a524373/Srbiju-mesecno-napusti-vise-od-4.000-ljudi.html.

Vučić poljubio je kinesku zastavu i obećao slušati diplomaciju kako bi izbjegli,katastrofalan talijanski scenarij, Direktno, https://direktno.hr/eu-i-svijet/vucic-poljubiokinesku-zastavu-i-obecao-slusati-diplomaciju-kako-biizbjegli-katastrofalan-talijansk-189142/.

World Happiness report 2020, https://worldhappiness.re- 
port/ed/2020/social-environments-for-world-happiness/.

Zivanović M., Russia Military Deal Deemed' Good Thing' For Serbia, Balkan Insight, http://www.balkaninsight. com/en/article/new-serbian-russian-military-deal-goodthing--04-04-2018.

\begin{abstract}
The chapter will present the current problems and challenges regarding Serbia's relations with selected international actors. Initially, the socio-economic situation in the country will be outlined based on reports from 2020, including World Bank, Transparency International, Freedom House, World Happiness. Then, Serbia's relations with Russia, the United States, the European Union, and China will be presented. In addition, the text deals with the important subject of the current "vaccine diplomacy", that is, relations between countries determined by the current global situation.
\end{abstract}

Keywords: Balkans, Serbia, China, international relations, Russia, European Union, United States of America

\begin{abstract}
Abstrakt
Praca prezentuje obecne problem i wyzwania stojące przed serbskimi relacjami z wybranymi aktorami międzynarodowymi. Sytuacja społeczno-ekonomiczna w państwie zarysowana jest na podstawie raportów i sprawozdań za 2020 rok, w tym Banku Światowego, Transparency International, Freedom House czy World Happiness. Następnie omówiono relacje Serbii z Rosją, Stanami Zjednoczonymi, Unią Europejską i Chinami. Ponadto w tekście poruszono zagadnienie "dyplomacji szczepionkowej", będącej skutkiem obecnej sytuacji na świecie I determinującej kształt relacji między państwami.
\end{abstract}

Słowa kluczowe: Bałkany, Serbia, Chiny, stosunki międzynarodowe, Rosja, Unia Europejska, Stany Zjednoczone 


\author{
Małgorzata Polkowska \\ University of War Studies \\ ORCID ID: https://orcid.org/0000-0002-6633-2222
}

\title{
Space Security in Asia-Pacific Region ${ }^{1}$
}

\section{Introduction}

The political situation in the Asia-Pacific region is complex. Asia is undergoing strategic changes due to changing global and regional conditions. Growing political and territorial problems put more pressure on the application of complex solutions, also in space. The first successful test in China in January 2007 indicates a new stage in space security competition between Asian powers (including China, India, and Japan). The Russian Federation and the United States are also pursuing their policies in this area. Asian countries either form various alliances or conflict with each other. China has the strongest position (in conflict with the USA and India), which, among others, supports North Korea (as does the Russian Federation). Japan, South Korea, and Australia can count on American aid. After 1991, when the USSR was dissolved, its former ally, India, established closer relations with the US and the European Union. The Indian ASAT test in 2019 , however, could put the country in serious trouble ${ }^{2}$.

1 This publication is financed under the project implemented in the Research Grant Program of the Ministry of National Defense, Republic of Poland.

2 B.E. Bowen, War in Space. Strategy, Spacepower, Geopolitics, Edinburgh 2020, p. 27. 
Most of the countries in the region rely on the US Global Positioning System (GPS), which serves over a billion users worldwide. The systems of the Russian Federation (GLONASS) and China (BeiDou (also known as KOMPASS) are local. India has recently been building its own IRNSS (Indian Regional Satellite Navigation System), and Japan is doing the same by building the QZSS (Quasi-Zenith Satellite System). These areas are also reached by the European positioning system Galileo, all of which are based on information from their satellites and data obtained from the American and European SDA / SSA databases ${ }^{3}$.

\section{China}

Until 2002, aid to the Chinese space programme was provided by the United States, the Russian Federation, the former Soviet republics, Canada, the United Kingdom, Germany, and Brazil. In the United States, this collaboration sparked a great political dispute and led to an investigation in Congress. Gradually, China became more and more space competition. In 2003, Zhang Houying, a space application specialist at the Chinese Academy of Sciences, said that the Shenzhou V space probe was equipped with military surveillance equipment - a camera with a resolution of 1.6 meters.

The 2015 White Paper on Defense of China recognized space as a military domain for the first time and linked the development of the international security situation with the defense of China's interests in space. Chinese military journals state that the goal of hostilities and space operations is to

3 R.P. Rajagopalan, Space security in Asia-Pacific Region, [in:] Handbook of Space Security, ed. Kai-Uwe Schrogl, vol. 1, Switzerland 2020, pp. 499-513 . 
achieve space superiority. The space advantage is defined as "ensuring the ability to fully use space while limiting, weakening, and destroying the enemy's space forces. It includes not only offensive and defensive operations in space against the enemy space forces but also air, ground, and naval operations".

In recent years, China has embarked on a major reorganization of its army and established Strategic Support Force (SSF) troops as its fifth military service by merging existing space, cyber, and electronic warfare units under a new unified command that reports directly to the Central Military Commission. The intention is to transform the People's Liberation Army into a modern multi-domain army ${ }^{4}$.

China has the technology it needs to disrupt the space system, from lasers and cyber capabilities to rockets. The latter has been used in several ASAT tests over the past decade: the first, in 2007, caused massive controversy worldwide due to the number of debris produced. It raised concerns in the United States because it proved that China could become a severe challenge in the future. Other tests, not officially recognized as ASAT and sometimes referred to as "intercepting missile defense tests", took place in 2010-2018. The 2013 experiment showed that China could reach a geosynchronous orbit, thus endangering US early warning and telecommunications satellites ${ }^{5}$.

According to American intelligence data from 2019, China has a solid network of sensors capable of searching, tracking, and characterizing satellites in all orbits on Earth. This network includes various telescopes, radars, and other

4 R.S. Jakhu, J.N. Pelton (eds.), Global Space Governance: An International Study, Switzerland 2017, p. 93.

5 ESPI report, Europe, Space and Defence. From "Space for Defence” to „Defence of Space”, pp. 6-11. 
sensors that allow China, among other things, to support missions, including intelligence gathering, early warning of ballistic missiles and dangers to satellites, and space debris monitoring. The Chinese Army is considering the possibility of Electronic Warfare (EW) and is developing its doctrines and devices for this purpose. China is likely developing laser weapons to disrupt, destroy or damage satellites and enemy space weapons in low Earth orbit. In addition, China points to the possibility of using its cyberspace capabilities to limit the enemy's actions.

China leads the Asia-Pacific Space Cooperation Organization, whose members include Iran, Pakistan, and Peru; a project called Asia-Pacific Ground-Based Optical Space Observation System (APOSOS) was also created. As part of this project, China has delivered three $15-\mathrm{cm}$ telescopes to Peru, Pakistan, and Iran, capable of tracking objects in the LEO and GEO orbits. All observation data is sent to the Astronomical Observatory of the Chinese Academy of Sciences ${ }^{6}$.

Some comments on possible Chinese space attacks, however, are more balanced. For example, B. Mulvaney, an American representative of the China Aerospace Studies University, believes that China has all programmes, including SDA and SSA. However, its main focus is on protecting its facilities. Space is no longer a "sanctuary" but a place for politics and military goals. China, so far, is not trying to start a space war but is focusing on scientific and experimental goals ${ }^{7}$.

6 Defense Intelligence Agency, Challenges to security in Space, Committed to Excellence in Defense of the Nation, January 2009, p. 28, https:// www.dia.mil/Portals/27/Documents/News/Military\%20Power\%20Publications/Space_Threat_V14_020119_sm.pdf [access: 20.01.2021].

7 B. Mulvaney, Operating against near peer adversaries - implications for SSA, SMI's Military Space Situational Awareness 2020 Conference, September 3-4, 2020. 
China also joined the Interagency Coordination Committee for Space Debris (IADC), which was established in 1993. They organized an expert group to develop a space pollution mitigation programme. China is gradually adopting space debris design and management standards. In line with international conventions, they intend to install appropriate devices in Long March missiles to reduce the amount of active waste. China declares that it will develop space debris monitoring and spacecraft protection from space debris and collisions with other satellites ${ }^{8}$ in the future.

China has offered to cooperate with other countries on its lunar missions. It is to raise the country's prestige as a leader of a peaceful action in space. India (China's longtime opponent) also received such an invitation - by 2036, they would co-implement the Chinese plan to study the Moon. Another Chinese initiative is inviting countries to use their "BeiDou" navigation system. Simonetta di Pippo, director of the United Nations Office for the Peaceful Uses of Outer Space (UNOOSA) ${ }^{9}$, signed an appeal with representatives of China to UN member states to submit applications for participation in the work of the future Chinese space station. This Chinese initiative has been called by the South African Union the Marshall Peace Plan.

China, looking for raw materials in space, signed a Memorandum of Understanding with Luxembourg and established a space research unit in the Grand Duchy, mainly due to the liberal regulations. In return, the Bank of China en-

8 L. Long, D.L. Lin Shen, L. Hongbo, Z. Don, Z. Shengjun, Chinese Space Launch Program, [in:] Handbook of Space Security, ed. Kai-Uwe Schrogl, vol. 2, Switzerland 2020, pp. 1402-1418.

9 www.unoosa.org [access: 2.03.2021]. 
tered into a contract with Luxembourg to sell Chinese bonds (worth $\$ 500$ million) to construct a space station ${ }^{10}$.

Already at the beginning of the $21^{\text {st }}$ century, the Chinese authorities found the SSA programme very useful. So it was decided to develop a technology for monitoring space debris and build a system to protect spacecraft from their operation. In addition, it is planned to expand the satellite collision warning system and start monitoring small celestial bodies near the Earth (NEO).

In December 2008, the Main Laboratory for the Observation of Space Objects and Remnants of the Chinese Academy of Sciences was officially opened at the Purple Mountain Observatory (PMO) in Nanjing. Currently, PMO has six external observation stations. The Delinha observation station is the largest radio astronomy observation base in China; it has a 13.7 -mm radio astronomy telescope, a moving sub-millimeter-wave telescope, a cosmic optoelectronic telescope, and other large astronomical observation devices. Xuyi Observation Station is the only celestial mechanics measuring base in China; The largest Chinese telescope (1 $\mathrm{m} / 1.2 \mathrm{~m}$ ), the NEO telescope for detection, and an optoelectronic space telescope for the detection of space debris were installed here.

On June 8, 2015, the Space Remnants Observation and Application Center was established, which provides technical support for entities dealing with space debris. As a result, China has improved the processes of monitoring, early warning, and protection against space debris and improved standards and regulations in this area. Monitoring and ear-

10 N. Goswami, China's grand strategy in outer space: to establish compelling standards of behavior, https://thespacereview.com./article/3773/1 [access: 8.09.2020]. 
ly warning against space debris ensure the safe operation of spacecraft in orbit. China has also achieved success in the design technology for protecting spacecraft from space debris. In addition, all Long March launchers can decommission the upper stage safely, and old spacecraft are taken out of orbit to protect the space environment. China is also working on space weather issues ${ }^{11}$.

The Chinese government supported the project to establish the STM (Space Traffic Management) system. While the term has not yet been mentioned in any of the national legal and political documents, Yang Kuan of the Beijing Institute of Technology stated that "Chinese laws and policies undoubtedly could form the basis of an STM programme". At the same time, Chinese officials recognized that since the actions in space are international, the establishment and implementation of the STM system should be based on the international legal system, and the national approach should not be privileged ${ }^{12}$.

\section{India}

In 1975, India launched its first satellite, Aryabharata. Next is the Satellite Launch Vehicle (SLV) - the first Indian carrier satellite launched in 1980. ISRO (Indian Space Research Organization) boasts the Chandarayaan-1 unmanned moon probe launched in 2008 and the Mars Orbiter Mission probe, which reached orbit in 2014 Mars. India is, therefore,

11 L. Long, D.L. Lin Shen, L. Hongbo, Z. Don, Z. Shengjun, Chinese Space Launch Program, [in:] Handbook of Space Security, ed. Kai-Uwe Schrogl, vol. 2, Switzerland 2020, pp. 905-920.

12 ESPI, Towards a Europe Approach to Space Traffic Management, Vienna, January 2020, pp. 31-33. 
the first country to orbit Mars on its first attempt successfully.

In $21^{\text {st }}$ century India, the discussion on the commercialization of the space economy intensified. The space industry in India suffers from a lack of capital, mainly due to limited domestic market opportunities. Despite this, the Space Research Organization has world-class infrastructure, especially in communications, satellite navigation, and Earth observation. Currently, there are 58 Indian satellites in orbit, which gives India sixth place in the world. The Indian space economy is valued at $\$ 7$ billion, accounting for about $2 \%$ of the world's space economy. Therefore, it was concluded that to fulfill its aspirations, India must create an active fund that will support its domestic space industry, which will provide the state and citizens with greater security. Soon, the Indian government decided to help the state-owned space sector for private companies and cooperate closely with the Indian Space Research Organization (ISRO). It was considered an essential step in India's policy toward joining the elite group of space powers ${ }^{13}$.

After several decades of running a purely civil space programme, India adopted a military space programme at the beginning of the $21^{\text {st }}$ century. It was for several reasons. Skirmishes with Pakistani forces in Kargil in 1999 showed that Indian space assets were ineffective in such a military situation. Even more important was China's 2007 ASAT, which was considered a "wake-up call" to Indian leaders. In 2008, the Integrated Space Cell (ISC) was established at the headquarters of the Integrated Defense Staff. It was primarily aimed at coordinating Indian military activities in space

13 R.S. Jakhu, J.N. Pelton (eds.), Global Space Governance: An International Study, Switzerland 2017, p. 93. 
and overseeing space security and the use of Indian military and civilian space equipment resources.

That same year, India published "Defense Space Vision 2020", a new doctrine that emphasizes the military aspects of outer space. This document called, among other things, to increase dual-use assets and to build a military space operational capability within the ISC. In addition, it was decided to create the Defense Space Agency (DSA) to counteract threats to the space potential and for close cooperation with the Indian Space Agency (ISRO) and the Defense Research and Development Organization (DRDO).

This agency should form the backbone of any future space-focused military command. Under its authority is the Defense Space Research Organization (DSRO), which provides DSA with research support by developing advanced weapons systems and technologies for waging war in space.

Evolution also took place on the operational front. In line with the new doctrine, the development of dual-use capabilities for space intelligence gathering and regional navigation and communication capabilities has become a priority for ISRO. Therefore, currently, the use of space potential for passive military missions focuses on three tasks: intelligence, navigation, communication.

Therefore, the integration of space potential in Indian military thought has gained strategic priority and political attention since 2008. In 2013, the armed forces' space requirements were collected and defined. In addition, in the same year, the first satellite intended solely for the military was launched. Fearing an attack by China, the country considered developing deterrents to protect its assets and has declared its ability to shoot down satellites for several years. 
However, India does not have a comprehensive military space programme. Due to geopolitical realities, they must show that their defense is ready to repel a hostile attack from space. India has therefore taken many steps, including preparations for the ASAT weapons tests ${ }^{14}$.

Such a test was carried out on March 27, 2019, by destroying the Indian satellite located on LEO. The Indian Ministry of Foreign Affairs stated that the test was conducted as a necessary component "to test whether India is capable of securing its space potential". It was also deemed necessary to decoupling the Indian SSA programme from overseas. Shortly after that, India's Prime Minister Narendra Modi instructed the National Security Adviser to create a space doctrine draft, and the IndSpaceEx war game was organized in July 2019.

Many countries joined the Indian test, including the US, China, and the Russian Federation, arguing that it will cause a huge increase in space debris. On July 26, 2019, the head of the Russian Space Agency (Roscosmos), Dmitry Rogozin, announced preparations to start international negotiations on a ban on full-scale testing of anti-satellite weapons. Despite the renewal of this intention, negotiations have not yet taken place.

\section{Japan}

Japan has long been one of the most staunch advocates of outer space as the domain of peace. In its 1969 space law, it

14 A. Lele, India in Space: A Strategic Overview, [in:] Handbook of Space Security, ed. Kai-Uwe Schrogl, vol. 1, Switzerland 2020, pp. 571-587 . 
adopted a very restrictive interpretation of the peaceful use of outer space as described in the 1967 Outer Space Treaty ${ }^{15}$, claiming that "peaceful" means "non-military" and not merely "non-aggressive", contrary to this, which most other countries understand. As a result, space resources, and even the data resulting from them, could not be used by the Japanese armed forces ${ }^{16}$.

However, this radical position has evolved. In 1985, the Self-Defense Forces were authorized to use data from commercial satellites. In 1998, the IGS (Information Gathering Satellite) programme was launched to track North Korean missile tests over Japan. Defense satellites have been launched since 2003. Like India, 2008 appears to be a turning point for Japan. The space law published this year left open the possibility of using outer space for military pur$\operatorname{poses}^{17}$.

In the face of the growing arms race in Asia, the Japanese authorities are striving to strengthen their defense capabilities as soon as possible. To this end, in mid-December 2019, the government approved the record-breaking draft defense budget for 2020. It assumes an increase in spending on cybersecurity and activities in space. In total, according to the draft, Japan is to allocate a total of 5.31 trillion yen $(\$ 48.5$ billion) on defense. Importantly, this is expected to be the eighth year that Japan has been increasing defense spending under Prime Minister Shinzo Abe. The current draft of the

15 https://www.unoosa.org/oosa/en/ourwork/spacetreaties/introouterspacetreaty.html [access: 3.04.2021].

16 S. Nakamura, Research and Activities on SSA at JAXA, Tokyo symposium, March 8, 2018.

17 ESPI report, Europe, Space and Defence. From "Space for Defence” to „Defence of Space”, pp. 55-56. 
Japanese defense budget assumes an increase in spending on US military bases in this country (by 1.1 percent compared to the previous year. It is estimated that about 50.6 billion yen will be allocated to improving space capabilities ${ }^{18}$.

At the same time, the first space unit to be created as part of the Japanese Air Self-Defense Force is to be created. It is to detect electromagnetic disturbances directed against Japanese satellites and monitor space debris and unidentified objects in outer space. In addition, Japan is striving to strengthen its missile capabilities against the potential enemy, namely North Korea. Tokyo plans to spend around 12.9 billion yen to get the US Aegis Ashore land-based missile defense battery system. A total of 25.6 billion yen is planned to be spent on cybersecurity. The Japanese authorities are primarily planning a significant expansion of the country's cyber defense unit, which was established in 2014. First of all, it is about quickly increasing its personnel from 220 to 290 people. It should be recalled that the latest national defense guidelines adopted in December 2018 by the Tokyo authorities identified cybersecurity and space as essential domains affecting national security ${ }^{19}$.

Currently, Japan has an infrastructure for Space Situational Awareness (SSA) activities, which in addition to Space Surveillance and Tracking (SST), also includes Space Weather (SWE) and Near Space Objects (Near Objects NEO). These issues are dealt with by a) the Kamisaibara Space Protection Center (radar observation), located in the Okayama Prefecture, b) the Bisei Space Protection Center

18 S. Ogawa, SSA activities at JAXA, Tokyo symposium, February 28, 2019.

19 https:// www. defense 24.pl./kolejny-rekordowy-budżet-obronny-w-japonii [access: 23.03.2021]. 
(optical observation), located in the same prefecture, c) the Tsukuba Space Center (data analysis), located in the Okayama Prefecture located in Ibaraki Prefecture.

Japan has, among others, $1.6 \mathrm{~m}$ class radar operating at a distance of about $650 \mathrm{~km}$ and modern telescopes, which makes it possible to observe approx. 30 thousand objects. The Japanese Space Agency (JAXA) uses these devices to perform the following tasks: 1) monitoring space debris, 2) creating databases from information collected in orbits, 3) analyzing their approach to satellites, 4) the possibility of their reintroduction into the atmosphere. JAXA also cooperates with other Japanese agencies dealing with SSA problems, including The Airspace Search Agency ${ }^{20}$.

Since 2015, Japanese research on space weather has been carried out under the project "Project for Solar-Terrestrial Environment Prediction" (PSTEP). Scientists from the National Institute of Information and Communication Technologies (NICT), Kyoto University, and Nagoya University are researching topics ranging from the magnetosphere and ionospheric dynamics to the solar cycle, solar storms, and weather forecasting in space. Japan's NICT runs the Space Weather Forecast Center (ISES), continuously providing space weather information since 1988. As a result, Japan became part of an agreement of 16 countries (established in 2010) that exchange data on space weather in the AsiaPacific region (Asia-Oceania Space Weather Alliance - AOSWA).

Japan has also joined international actions to increase knowledge about NEO and its monitoring. For example, as

20 Securing Japan. An assessment of Japan's strategy for space, Report: Title: “ESPI Report 74-Securing Japan-Full Report, July 2020, pp. 34-36 . 
early as 2010, the Japanese spacecraft Hayabusa 1 landed on the small, near-Earth asteroid "Itokawa" and returned to Japan with samples of the local surface.

Soon, JAXA intends to build three objects designed to track space debris: a low-orbit radar with a range of 200 to $1000 \mathrm{~km}$, an optical telescope for observing a high orbit of $36,000 \mathrm{~km}$ (orbit of communication and weather satellites), and an analytical system for recognizing debris, spacecraft, their approach to satellites and re-entry into the atmosphere. These three satellites will work together. Subsequent plans provide for the modernization of the radar (it will be able to observe objects of the $10 \mathrm{~cm}$ class, compared to the current $1.6 \mathrm{~m}$, at an altitude of $650 \mathrm{~km}$ ), the frequency of observations (from 200 times a day to 10,000) and the data processing capacity will increase. There will also be a new optical telescope that will be able to track up to $100,000^{21}$.

\section{South Korea}

Korea's space programme was created almost 40 years ago and has lagged behind that of developed countries. In the following years, the state focused on making up for the backlog of technology; however, there is still no industry producing space equipment or even communication between industry and scientists. On the other hand, there is too much concentration on projects and initiatives at the Korean Space Research Institute (KARI). Therefore, it is proposed that the Institute increase its efforts to promote the Korean space industry by encouraging technology transfer, equipment sharing, and developing enterprise com-

21 Ibidem; ESPI full report, Vienna. 
munication. The institute must change its character from a pure research laboratory and become a manager supporting the development of the space industry ${ }^{22}$.

South Korea announced in 2016 that it intends to orbit five reconnaissance satellites by 2022, which will constitute the early warning system for ballistic missiles taking off from North Korea. Authorities in Seoul want a constellation of reconnaissance satellites to be developed in South Korea as part of the "Kill chain". The network is to be part of the North Korean ballistic missile detection and destruction system. The entire project was to be overseen by the South Korean Defense Acquisition Programme Administration (DAPA). The contract for its implementation was to be signed at the end of 2016. The first satellite was to be in orbit in 2020, and the remaining four in 2022. A modern radar was to be constructed by DAPA, while infrared electro-optical systems - KARI (Korea Aerospace Research Institute). The entire project was to cost over $\$ 900$ million $^{23}$.

KARI, Korea's leading aerospace research institute, recently published its "Space Development Strategy for the Medium to Long Term". The report sets out plans for a lunar landing mission by 2020 and a trial lunar return mission by 2030. The report also includes a Mars exploration programme, with an in-orbit and lander mission completed by $2030^{24}$.

There is currently an Optical Patrol Network (OWL-Net) in Korea, with five optical telescopes at different locations

22 J. Lee, Policy for latecome countries, „Space Policy” 2011, vol. 27, no. 4.

23 Korea Aerospace Research Institute, https://www.kari.re.kr [access: 2.04.2021].

24 https://spacegeneration.org/regions/asia/ [access: 31.03.2021]. 
around the world. It is the only infrastructure for Korean SSA programmes. However, due to the dependence of this network on weather conditions and observation time, they have limited operational availability. So it was decided to consider the development of radar systems. Therefore, the National Space Situational Awareness Organization (NSSAO) initiated a conceptual study of the operation of the space observation system using the existing optical system and the radar system necessary for effective operation. The NSSAO is conducting preliminary research into the development of effective SSA radar systems ${ }^{25}$.

The history of space research in Australia dates back to the 1960s. The country was the seventh to put a satellite (WRESAT) into orbit. The launch was carried out in 1967 from the Woomer base with the Sparta rocket, the design of which was based on the American Redstone ballistic missile. The Europa 1 rocket, developed by ELDO (European Launcher Development Organization), one of the precursors of the European Space Agency, was also launched by Woomer. However, orbit failed, and the programme was abandoned. In south-eastern Australia, an antenna system has also been in operation since 1965, as part of the Deep Space Network, monitoring communication in missions exploring the Solar System. The antennas listened to the Apollo, Viking, and Voyager missions, among others. In the west of the country, the European Space Agency also has its listening system.

However, from the late 1960s onwards, Australia's space activity was severely restricted; it was resumed only after

25 S. Choi Eun-Jung, J. Cho, J. Hyun Jo, T. Hyun Park, J. Chung, H. Park, A. Jeon, Y.L. Yun, Performave Analysis of Sensor System for Space Situational Awareness, "Journal of Astronomy and Space Sciences" 2017, vol. 34, no. 4, pp. 303-313. 
20 years. Probing rocket projects (SSRP, AUSROC) were carried out, but it was not possible to develop these programmes into the functional stages of small orbital rockets.

In 2017, the International Astronautical Congress (IAC) was held in Australia - an event where the leading representatives of the space sector: the largest companies, space agencies, and politicians, meet. At that time, a representative of the SpaceX company clarified the "Martian plans". Already during the IAC, it was known about the end of preparatory work for the establishment of the Australian Space Agency.

The establishment of this institution was announced on May 8, 2018. The Australian Space Agency received 25 million Australian dollars for its own operations and 16 million Australian dollars for an investment fund supporting Australian space companies. The agency was to be responsible for creating and implementing the space strategy and the development of the national space policy. The Australian Civil Space Strategy, which defined a 10-year plan for the transformation and development of the space industry, was soon developed. This document also covers "Space Situational Awareness" (SSA) and the monitoring of waste left in space.

The geographical location of Australia in the southern hemisphere, the low level of light and radio interference provide a unique opportunity for the development of the commercial industry, operating in tracking space objects (mainly EOS Space Systems). EOS space sensor network tracks approx. Ten thousand space objects per week. EOS intends to expand its activities to other places far away from civilization in Australia. The Australian Space Agency predicts that by 2030 profits from the space industry and 
services will increase from 3.9 to 12 billion dollars and create 20 thousand new jobs. Australia's 10-year plan for the civil space sector will give the country a greater share of the global space economy, currently worth around $\$ 350$ billion.

Favorable terrain conditions and friendly policy of local authorities meant that the largest private space rocket test center in the world is currently being built in South Australia. They are created by Southern Launch, which already owns a similar place - Orbital Launch Complex, and hope to attract private companies and universities to Australia to test their rocket technologies. In the Orbital Launch Complex, rockets are launched towards the ocean. The new center, the Koonibba Test Range, will cover an area of $145 \mathrm{~km}^{2}$ and will be located 600 kilometers northwest of Adelaide, near the town of Ceduna. Rockets fired there will land on land, so their owners will be able to collect and study them. Koonibba Test Range Site is being built on land belonging to 200 members of the Koonibba people. Kevina Ware, at its head, said: "We will be Australia's first indigenous people to have a commercial spaceport. This is a historic achievement; its cooperation with the Australian Space Agency is going very well”26.

Australia is increasing its share of the Global Space Situational Awareness (SSA) programme by committing to the procurement and maintenance of SSA sensors. During 2017, a series of collaborative experiments with US operators were undertaken to demonstrate the capabilities of Australian sensors. As a result of the tests, data exchange and communication protocol were developed that brought together

26 M. Błoński, Powstaje największe na świecie prywatne centrum testowe rakiet kosmicznych, https://ui.adsabs.Harvard.edu/abs/2017amos [access: 23.03.2021]. 
partners from the defense, academia, and industry sectors.

Telescopes from Falcon in Canberra, Raven in Exmouth (Western Australia), and Defense Science and Technology (DST) in Adelaide (South Australia) exchange their observations. The Murchison Widefield Array (MWA) in Western Australia demonstrated the capabilities of passive radar by successfully observing satellites on the LEO (based on reflected terrestrial radio signals). This combination of radar and optical telescopes under the SSA programme can be used throughout Australia ${ }^{27}$.

Australia owns many geostationary communications satellites that serve the Australian civilian population and the Australian Army's military operations. To fulfill these tasks, Australia must cooperate with foreign entities, so it has concluded many military agreements with allies and transactions with manufacturers of space devices. The goal of the Australian Air Force is to use the SSA's ability to gather information on threats to both Australia and its allies and partners. Under international agreements, each country is responsible for the objects it put into orbit throughout their operation cycle. Currently, Australia is responsible for 18 objects in orbit, including 14 operational satellites, two worn rocket amplifiers, and two defunct satellites.

Australia's contribution to SSA operations is primarily based on ground-based space surveillance sensors - the joint use of USAF C-band radar and the DARPA Surveillance Space Telescope at Exmouth, with S\&T support from DSTO, laser tracking by EOS on Mount Stromlo, a classic orbital al-

27 B.T. Morreale, M. Bessell, B. Rutten, Australian Space Situational Awareness Capability Demonstrations, 2017 Advanced Maui Optical and Space Surveillance Technologies Conference (AMOS) - www.amostech. com. 
gorithm by RMIT in support of the work of EOS and complimentary tracking by the new UNSW Canberra telescope, part of the growing global Falcon telescope network ${ }^{28}$.

For Australia, 2020 was another period of steady and steady progress in many key areas. The updated Defense Strategy 2020 update in July and the accompanying Armed Forces Structure Plan made it clear that the government now views space as a critical operational domain in its own right that requires more attention and investment - at least AU \$7 billion over a decade. In particular, it highlighted the importance of Australia developing "state-controlled" space satellite communications capabilities and geospatial remote sensing and the importance of ensuring space control. It has severe consequences for the future, not only for the Australian space force but also for the development of the Australian private space industry, which will supply it with modern equipment. Ensuring the rapid development of this sector is a priority for the Australian Space Agency.

Australia plans to produce small satellites that can directly complement larger and more complex (and more expensive) satellites to meet the requirements of two key defense projects. These are: "DEF-799 Phase 2" for statecontrolled space intelligence, surveillance, reconnaissance, and "JP-9102B" for next-generation satellite communications. Both will be state-controlled, but there are likely to be larger, more complex satellites purchased from abroad.

The third element that seems to be ready for implementation is the possibility of regularly launching Australian satellites from Australian spaceports. They are planned to be established in 2021 in Nhulunbuy (Northern Territory),

28 https://www.unsw.adfa.edu.au/space-research/research-themes/ spacesituational-awareness [access: 4.02.2021]. 
Whalers Way (South Australia), and Bowen (Queensland). The leading company is Gilmour Space Technologies, which plans to launch Eris 1 in 2022, and Black Sky Aerospace developing missile technologies.

Public interest in space has never been greater and continues to inspire the next generation of space leaders. Fortunately, the impact of the COVID-19 pandemic has not caused the Australian space sector to shrink or to a decline in government support for the development of this new national venture ${ }^{29}$.

\section{Conclusion}

Despite there is a growing concern in the Asia-Pacific region about space security, tensions between the countries in the region can be reduced, at least in part, by developing Space Situational Awareness (SSA). This system prevents the degradation of space and enables its safe exploitation, which is beneficial for all states operating in outer space.

The development of space security (and Space Situational Awareness) systems in the Asia-Pacific region and the exchange of data (mainly open data) do not encounter political obstacles. However, not all countries support the principle of the safe operation of foreign satellites. SDA/SSA systems are acceptable to all countries involved in space activities; and can help reduce tensions between countries. SSA and STM can create "traffic rules" for all users of Space worldwide.

29 M. Davis, Australia's space sector should aim higher, SpaceWatch GL, https://spacewatch.global/2020/12/spacewatchgl-opinion-australiasspace-sector-should-aim-higher-by-malcolm-davis/ [access: 23.12.2020]. 


\section{Bibliography}

Błoński M., Powstaje największe na świecie prywatne centrum testowe rakiet kosmicznych, https://ui.adsabs.Harvard.edu/abs/2017amos.

Bowen B.E., War in Space. Strategy, Spacepower, Geopolitics, Edinburgh 2020.

Choi Eun-Jung S., Cho J., Hyun Jo J., Hyun Park T., Chung J., Park H., Jeon A., Yun Y.L., Performance Analysis of Sensor System for Space Situational Awareness, "Journal of Astronomy and Space Sciences" 2017, vol. 34, no. 4.

Davis M., Australia's space sector should aim higher, SpaceWatch GL https://spacewatch.global/2020/12/spacewatchgl-opinion-australias-space-sector-should-aimhigher-by-malcolm-davis/.

ESPI report, Europe, Space and Defence. From "Space for Defence" to "Defence of Space".

Global Counterspace Capabilities: An Open Source Assessment, Space Threat Assessment, 2019.

Goswami N., China's grand strategy in outer space: to establish compelling standards of behavior, https://thespacereview.com./article/3773/1.

https://www.defense 24.pl./kolejny-rekordowy-budżetobronny-w-japonii.

https://www.unoosa.org/oosa/en/ourwork/spacetreaties/ introouterspacetreaty.html.

https://spacegeneration.org/regions/asia/. Jakhu R.S., Pelton J.N. (eds.), Global Space Governance: An International Study, Switzerland 2017.

Lee J., Policy for latecomer countries, "Space Policy" 2011, vol. 27 , no. 4 . 
Lele A., India in Space: A Strategic Overview, [in:] Handbook of Space Security, ed. Kai-Uwe Schrogl, vol. 1, Switzerland 2020.

Long L., Lin Shen D.L., Hongbo L., Don Z., Shengjun Z., Chinese Space Launch Program, [in:] Handbook of Space Security, ed. Kai-Uwe Schrogl, vol. 2, Switzerland 2020.

Morreale B.T., Bessell M., Rutten B., Australian Space Situational Awareness Capability Demonstrations, 2017 Advanced Maui Optical and Space Surveillance Technologies Conference (AMOS) - www.amostech.com.

Mulvaney B., Operating against near peer adversaries implications for SSA, SMI's Military Space Situational Awareness 2020 Conference, September 3-4, 2020.

Nakamura S., Research and Activities on SSA at JAXA, Tokyo symposium, March 8, 2018.

Ogawa S., SSA activities at JAXA, Tokyo symposium, February $28,2019$.

Rajagopalan R.P., Space security in Asia - Pacific Region, [in:] Handbook of Space Security, ed. Kai-Uwe Schrogl, vol. 1, Switzerland 2020.

Securing Japan. An assessment of Japan's strategy for space, Report: Title: "ESPI Report 74-Securing Japan-Full Report, July 2020.

www.unoosa.org.

\begin{abstract}
Currently, there is a growing concern in the Asia-Pacific region about the state of space security. The changing dynamics of development, both in the Asia-Pacific region and globally, impact the region negatively. Some powers: China and the Russian Federation
\end{abstract}


are challenging the current geopolitical balance and are developing their military capabilities in space. Tensions between the countries in the region can be reduced, at least in part, by developing space situational awareness (SSA). This system prevents the degradation of Space and enables its safe exploitation, which is beneficial for all states operating in outer space.

Keywords: space security, Space Situational Awareness System, Asia-Pacific, sensor, satellite

\begin{abstract}
Abstrakt
Obecnie wzrasta poziom obaw o stan bezpieczeństwa przestrzeni kosmicznej w regionie Azji i Pacyfiku. Stale zmieniająca się dynamika rozwoju na świecie, a zwłaszcza w regionie Azji i Pacyfiku, ma negatywny wpływ na ten obszar geograficzny. Niektóre mocarstwa, np. Chiny i Federacja Rosyjska, zmagają się z uzyskaniem równowagi geopolitycznej, którą starają się stworzyć poprzez rozwój potencjału militarnego w kosmosie. Napięcia między państwami w regionie Azji i Pacyfiku można zmniejszyć przynajmniej częściowo, pod warunkiem że stworzony zostanie system monitorowania kosmicznego (ang. space situational awareness, SSA). Umożliwi on powstrzymanie degradacji przestrzeni kosmicznej oraz jej bezpieczne wykorzystanie, co przyniesie korzystne rezultaty wszystkim państwom prowadzącym działania w kosmosie.
\end{abstract}

Słowa kluczowe: bezpieczeństwo przestrzeni kosmicznej, Space Situational Awareness System, Azja-Pacyfik, czujnik, satelita 


\section{Adriána Gogová}

University of St. Cyril and Methodius in Trnava

\section{Andrea Čajková}

University of St. Cyril and Methodius in Trnava

ORCID ID: https://orcid.org/0000-0002-5951-1281

\section{Application of Selected Elements of Governance in the Chinese People's Republic as a Tool for More Efficient Governance of Public Administration in the Slovak Republic ${ }^{1}$}

\section{Introduction}

Public administration is one of the phenomena of the state's existence and the practical exercise of public power. In its very essence, it represents the administration of public affairs, which is implemented as a manifestation of executive power in the state. It is characteristic of this executive power that it is primarily a public power that has the state and other non-state entities that perform the administration of public affairs. At the state activity level, public administration can be defined as the state activity performed by the state in addition to legislation and the judiciary. At the level of activities of other the so-called public entities, different

1 This research was funded by the Cultural and Educational Grant Agency of the Ministry of Education, Science, Research and Sport of the Slovak Republic, grant number KEGA004/UCM-4/2018. 
from the state, public administration is a non-state activity of an executive nature, whose mission is to ensure the performance of state administration. Public administration consists of two components, namely state administration and self-government, which are further divided according to individual hierarchical levels of the organization.

It follows from public administration that it is an organized system with a complicated structure of power relations, ties, and the resulting processes. Public administration is derived from the calculation of power and self-governing bodies, which ensure the decisions of the legislature, the judiciary, and the executive in various branches and to a large extent.

State administration is considered an essential part of the system of public administration. It is a public administration performed by the state, while in each current state, the state administration is an irreplaceable part of the public administration. State administration is an individual type of state activity regulated by law, contains power goals and certain specifics of the procedure for achieving them.

Public administration has a very long history. The term public administration first appeared in the 19th century in Charles Bonnin's work "Principes d'Administration Publique" (Principles of public administration), published in 1812. The concept of public administration is a central concept of administrative law. This concept has its roots in Roman law, from where it was translated into other languages. The theoretical connection between power and effective governance and leadership has deep roots in human history, from Thucydides, Machiavelli, Thomas Hobbes to modern models of political power and their application in public administration. 
The current system of public administration of the Slovak Republic builds on previous historical experience and contains new elements implemented in it. It is necessary to realize that some imaginary final state of the public administration system cannot be achieved, as it is constantly subject to various qualitative and quantitative changes. The paper's aim is based on the theoretical background to apply selected elements of governance of the People's Republic of China to streamline the management of public administration in the Slovak Republic.

\section{Public Administration Management in the Slovak Republic}

In 1950-1989, there was a centrally managed planned economy in the territory of the Czechoslovak Republic (since 1960, the Czechoslovak Socialist Republic). A typical feature was that the state was the owner of almost all production goods and was also the sole owner of production and nonproduction enterprises. The state also managed and controlled the fulfillment of pre-determined economic goals, which were adopted as various medium-term or long-term strategic plans. An authoritarian political system, defined by Juan Linz, whose most important ideas are summarized in “Totalitarian and Authoritarian Regimes", prevailed and who argues that an authoritarian political system is a political system characterized by: limited political pluralism, a typical mentality (emphasis on patriotism, patriotism, social justice, equality or order) a degree of political mobilization, the exercise of power by a small political group within vaguely defined but predictable boundaries. 
As stated by J. Nemec ${ }^{2}$, J. Oravec ${ }^{3}$, or K. Morvay ${ }^{4}$, the change took place in the early 1990 s, when the social, political, and economic orientation of the Slovak Republic changed. The structure of the economy of the current Slovak Republic includes private enterprises and enterprises or organizations that belong to the state or in which the state has a significant share. In the current mixed economy, three basic sectors can be found within which the individual entities operate. These are the public sector, the private sector, and the third sector.

Governance in a democracy and its quality, as stated by E.J. Barrett ${ }^{5}$, depends not only on the quality of the activities carried out by elected representatives. The quality of activities, backed by unelected representatives, i.e., especially officials whose main task is to put political decisions into practice, is equally important for its smooth running.

In the second half of the 20th century, the public administration systems of European countries underwent extensive reforms that pursued several basic objectives. In addition to increasing economy and efficiency in the public sector, decentralization and modernization of public administration have become such goals.

2 J. Nemec, Po desiatich rokoch transformácie, "Ekonomický časopis" 2001, vol. 49, no. 4, pp. 587-629.

3 J. Oravec, Liberalizácia ekonomiky a deetatizácia spoločnosti, [in:] Slovensko: desat rokov samostatnosti a rok reforiem, eds. O. Gyárfášová, G. Mesežnikov, Bratislava 2004, p. 163.

4 K. Morvay, A. Kolektív, Transformácia ekonomiky: skúsenosti Slovenska, Bratislava 2005, p. 328.

5 E.J. Barrett, The Role of Public Opinion in Public Administration, "The Annals of the American Academy of Political and Social Science" 1995, no. 537, pp. 150-162. 
According to E. Žárska, T. Černěnko, and D. Kozovský, the introduction of decentralization processes led to a more intensive rapprochement of public institutions and services to citizens ${ }^{6}$. The transfer of competencies to lower levels of government, especially changes in the financing of competencies of lower levels of government, creates preconditions for increasing the efficiency and effectiveness of the resources spent. Nevertheless, even in countries where the process of decentralization has taken place in its various stages, "the still existing central government (center) has the ultimate power with respect to the given units the process of decentralization or reverse re-centralization is in the power of the center"

The problem with effective decision-making in the public sector is determining the ratio between centralized and decentralized decision-making, where the efficiency of the allocation of public goods and services is an important measure. As each state is based on different specific conditions, it is impossible to determine a unified prototype of the optimal relationship between centralization and decentralization. It is universally true that any specific function should be provided by the level of public administration that can do it most economically and efficiently, taking into account the spatial dimension of different types of public goods ${ }^{8}$. „Political parties in power in a democratic system apply their worldview view of the world in society, and public administration institutions serve them as components of the

6 E. Žárska, T. Černěnko, D. Kozovský, Verejná správa. I, Bratislava 2010, p. 176.

7 H. Vykoupilová, Víceúrovňové vládnutí v Evropě: koncepce, modely, typy, [in:] Víceúrovňové vládnutí v Evropě: zkušenosti, problémy a výzvy, eds. B. Dančák, V. Hloušek, Brno 2007, p. 17.

8 E. Žárska, T. Černěnko, D. Kozovský, op.cit. 
executive branch. Therefore, it is obligatory to set them to correspond to the adopted policy and at the same time to represent it. It can modify their internal structure as well as their external powers" 9

The problem of today's public administration is the unfinished model of public administration, insufficient control, growth and inefficiency of expenditures on public administration, management, neglected training of employees, and low level of knowledge and awareness of public administration. The lack of finances in all areas of public administration also creates considerable pressure on the management of its components.

One of the current problems in the current management of public administration is the number of bureaucratic processes. As part of the reforms introduced in the Slovak Republic, tools were created to simplify communication between the citizen and the state, respectively self-government (e.g., the portal "slovensko.sk"; client centers), where the state set rules that were to simplify communication between individual entities and through which it wanted to reduce bureaucratic processes. However, due to poor education, information, insufficient qualifications, and weak information technology skills for citizens, the majority of the population is unable to use these state tools effectively. At the same time, it should be noted that due to the legal obligation to use these tools for public authorities and the private sector, this obligation is ignored by them. The state hardly solves it at all (each

9 M. Cirner, A. Polačková, Ideologie jako součást politickoadministrativních korelací ve veřejném aparátu, [in:] MMK 2012. Mezinárodni Masarykova konference pro doktorandy a mladé vědecké pracovníky: sborník príspěvků $z$ mezinárodni vědecké konference, Hradec Králové 2012, p. 1360. 
citizen explains democracy in his own way and ignores obligations imposed by law). As it is voluntary (not all processes are voluntary - for the citizen only as a natural person, for other private and public entities it is a duty), the established processes do not reach $100 \%$ fulfillment, as is the case in the People's Republic of China, where democracy it has precisely defined boundaries. The state introduces these processes as mandatory.

The intention is to think about the problem of effective exercise of public power (I would probably use the word "power" here), which would correspond to current trends in the world and at the same time correspond to the current direction of public administration reform in the Slovak Republic.

An effectively functioning public administration should be a matter of course in any advanced democratic society. Its representatives (whether elected or appointed) are responsible for authorities, organizations, and institutions overseeing the administration of public affairs. The success or failure of government policy will be reflected not only in the country's economic growth or regions but also in the election process or citizens' dissatisfaction with meeting public needs. Woodrow Wilson's statement can be quoted here: "The state exists for the sake of society, not society for the sake of the state". means that the state exists because of society and not society because of the state.

\section{Public Administration Management in the People's Republic of China}

China is the oldest entity with a state continuity. The existence of this state unit is estimated from about 2200 BC. At 
the time of the Chan dynasty in $206 \mathrm{BC}$, an ingenious system of public administration was built, culminating in the medieval dynasties of Tchang (618-907) and Sung (960-1279). The ruler of the state of Cochin managed to establish the first centralized empire. Gradually, a bureaucratic system was built, which made it possible to control large areas.

Over the last hundred years, China has undergone turbulent political developments. The beginnings of the newly established state - the Republic of China - were complicated after 1912 and did not bring the expected political and economic stability. Developments in China in the 20th century were stamped mainly by two politicians, Chiang Kai-shek (1887-1975) and Mao Tse-tung (1893-1976), representing two decisive political forces: the Kuo-min-tang ("National Party") and the Communist Party of China. On October 1, 1949, Mao Tse-tung from the Gate of Heavenly Peace, forming the entrance to the former Forbidden City - the seat of the emperors of the Ming and Qing dynasties - declared the establishment of the People's Republic of China ${ }^{10}$.

According to M. Ćáky, the political and economic development in the People's Republic of China since 1949 can be divided into several groups ${ }^{11}$ :

- The period from 1949 to 1957: a period of economic recovery and growth, the creation of a new state, and the consolidation of Chinese communism.

- Period of the "Great Leap Forward" 1958-1960. The economic recovery since 1965.

- The period of the Cultural Revolution from 1966 to Mao Tse-tung's death in 1976.

10 I. Bakešová, O. Kučera, M. Lavička, Dějiny čínske lidové republiky (1949-2018), Prague 2019, p. 444.

11 M. Čáky, Čínske súvislosti, Dunajská Streda 2011, p. 295. 
- The period of the struggle for succession and the first period of reforms 1976-1989.

As several authors (R. Callick ${ }^{12}$, I. Bakešová, O. Kučera, M. Lavička ${ }^{13}$, A. Brown ${ }^{14}$ ) state, after the death of Mao Tsetung, the influential figure in Chinese politics was Deng Xiaoping. His "socialism with Chinese features" model allowed the Chinese to make full use of their entrepreneurship. His famous phrase "it doesn't matter if the cat is black or white, mainly because it catches mice". In other words, it is not important whether we call the economy capitalist or communist but whether it can meet the needs of citizens ${ }^{15}$. The introduction of the principles of the market economy in the 1980s gradually spread to all provinces. The Chinese economy started rocketing along with raising the living standards of the population. For the first time since the early 1980s, China has experienced a period of stability, prosperity, and development.

In 1978, China adopted a "one country - two systems" policy. Hong Kong was returned to China in 1997 and Macao in 1999. Both territories have acquired the status of a particular administrative area ${ }^{16}$. As Bakešová, Kučera, and Lavička point out, China thus put an end to its semi-colonial past and revealed its political strength and the integrity of its territory ${ }^{17}$.

12 R. Callick, Čas strany, aneb, Kdo a jak řídí Čínu, Prague 2015, p. 298.

13 I. Bakešová, O. Kučera, M. Lavička, Dějiny čínske lidové republiky (1949-2018), Prague 2019.

14 A. Brown, Vzestup a pád komunismu, Brno 2011, p. 901.

15 J. Hebnar, Obchod s Č́nou bez rizika a se ziskem, Prague 2016, p. 213.

16 V. Liščák, Dejiny Č́ny, Taiwanu a Tibetu v datech, Prague 2008, p. 598.

17 I. Bakešová, O. Kučera, M. Lavička, Dějiny činske lidové republiky (1949-2018), Prague 2019, p. 444. 
The 1990s and the first years of the $21^{\text {st }}$ century were marked by the implementation of reforms, China's opening up to the world, and efforts to integrate into the international community ${ }^{18}$. Theories of the "new Confucianism" and the "East Asian model of development" were revived, entrepreneurial activity developed, and the motto "socialist market economy" was coined. However, economic growth continued to be associated with political control in the form of a oneparty dictatorship.

Teng's model of modernized Chinese society allowed entry into the consumer world of the West, but the government was unwilling to hear voices calling for democracy. Neither Deng Xiaoping nor his current successors are interested in changing the authoritarian political system and resigning from the Chinese Communist Party's power monopoly ${ }^{19}$.

The People's Republic of China is a state with an authoritarian regime led by the Communist Party of China, which is no longer the only political party within the system but is the dominant party. In addition to the Communist Party of China, there are other democratic parties. They are independent organizations. They have political freedom and equality guaranteed by the Constitution before the law. Their relations and cooperation are based on the principle of long-term coexistence and mutual control. This system can be described as a dictatorship of the parliament, even though the preamble to the Constitution states that all power belongs to the people and speaks of a democratic dictatorship of the people ${ }^{20}$. As stated by Hebnar, the body

18 Ibidem.

19 M. Slobodník, Od posedného cisára k Maovi-dramatické premeny Č́ny v 20. storočí, "Historická revue" 2012, no. 7, pp. 38-45.

20 The leading role of the Chinese Communist Party is enshrined in 
through which this power is exercised is the General Assembly of People's Deputies and the Assembly of People's Deputies of the respective levels ${ }^{21}$. The China People's Political Consultative Assembly is the foundation of the Chinese political system. It is an essential institution of political party cooperation and political consultation under the leadership of the Chinese Communist Party and a form of socialist democracy in the country's political life. The primary mission is political consultation, democratic control of the progress of state bodies, and participation in the analysis and implementation of state affairs. Currently, it is a very well-organized body with its own general committee, a standing steering committee, nine special committees at the central level, and local committees in many localities ${ }^{22}$.

The People's Republic of China is a country with many nationalities and political parties. When it comes to taking measures or decisions on important issues, the Chinese Communist Party, as a leading political force, consults with all groups and parties. Today, we can safely and without thinking describe this party as a standard nationalist party with totalitarian tendencies in the exercise of its power, but at the same time with a developed social programme, which is also mixed with pragmatism about the country's economic development ${ }^{23}$.

the preamble to the Constitution, http://en.people.cn/constitution/constitution.html [access: 10.10.2020].

21 J. Hebnar, Obchod s Čínou bez rizika a se ziskem, Prague 2016, p. 213.

22 Political system and structure of state bodies, http://sk.chineseembassy.org/slo/ss/oc/t364423.htm [access: 10.10.2020].

23 Embassy of the People's Republic of China, http://cz.china-embassy.org/cze/zggk/t126984.htm [access: 10.10.2020]. 
Any statements calling for respect for human rights or criticizing the regime are being repressed by the authorities, citing the maintenance of stability and harmony as critical prerequisites for China's peaceful rise in the early $21^{\text {st }}$ century. The revolution of 1911-1912 aimed to establish a republic, end foreign domination and restore territorial integrity, and democratize China. The first two goals have been met over the last hundred years, and the third is a challenge for future generations of Chinese politicians.

\section{Picture no. 1. China's Leading Political Institutions}

The Communist Party dominates the Chinese political system

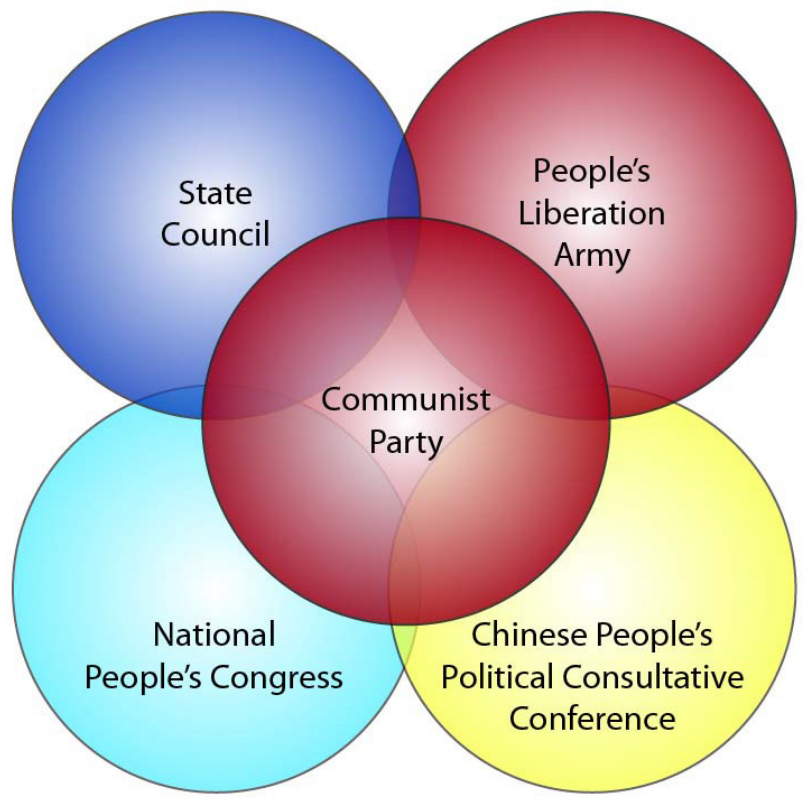

Source: S.V. Lawrence, M.F. Martin, Understanding China's Political System, Congressional Research Service Report for Congress, March 20, 2013, p. 7, https://www.fas.org/sgp/crs/row/R41007.pdf [access: 10.10.2020]. 


\section{Streamlining the Management of Public Administration in the Slovak Republic by Applying Selected Elements of Management in the People's Republic of China}

As stated by the former Prime Minister of the Slovak Republic and sociologist Iveta Radičová (2019): “The Slovak Republic belongs to the group of developed countries of the world. However, it shows persistent socio-economic problems, including significant regional disparities and structural labor market lags, a weak middle class, and a still low-income model of the economy. Due to globalization, technology, climate change, the demographic crisis, terrorism, migration, and industry lagging, along with the rule of law and the level of corruption, feelings of helplessness, hopelessness, fear, and anger prevail in society. Due to low confidence in the legislative, executive, judicial, and supervisory powers, critically poor and distorted law enforcement, a number of cases, especially unresolved issues, confidence in justice is deficient. Citizens feel disoriented, weaned, and used by politicians in power. Political culture is at a freezing point, and for this reason, the Slovak Republic is rightly understood as a pseudodemocracy". Phrases such as "political culture" or "political honor" or "political morality" are simply non-existent in the Slovak Republic, and they contradict each other in the conditions of our pseudo-democracy. Dominated by critical views of politicians as people with selfish motivation, low morals, and lack of interest in citizens ${ }^{24}$. Even the public's disgust

24 Z. Bútorová, O. Gyárfášová, Trendy vo verejnej mienke a voličskom správaní, [in:] Slovenské vol'by 2010. Šanca na zmenu, eds. Z. Bútorová et al., Bratislava 2011, pp. 152-153. 
with the unfair practices of politicians and corruption policy evokes in some of the public nostalgia for the communist era when undemocratic power did not burden the citizens with its disputes, and the public was faced with final decisions ${ }^{25}$.

China's political system has a long-term developmental advantage over pseudo-democracy in the European Union. In the last thirty years, the Chinese model of democracy management has never allowed such weak individuals to come to power as we see in the European Union and its Member States. China's political model opens up to greater democracy at all levels, and the European Union's democracy is collapsing. China is growing upwards. Economic growth has slowed to $8-9 \%$. The media consider it a terrible slowdown, while the economy in the European Union countries is almost not growing or is in decline. These countries do not have capable leaders or qualified economists in government, but they have capable propagandists in themselves.

For the last 70 years, the Chinese Communist Party has led people of all ethnic groups in China on a path of socialism with Chinese specifics that is appropriate to local conditions. The mentioned notion of socialism with Chinese specifics can be understood as a kind of bureaucratically controlled economy, which enables the existence of the state, semi-private and private sectors at the same time. It combines elements of socialism with a market economy. The regime adheres strictly to socialist doctrine. The central government has declared war on all fields of the socialist economy but still insists on adhering to the socialist path. The result is the separation of business from the govern-

25 Ibidem, p. 178. 
ment, the liquidation of small state-owned enterprises and their merging with other enterprises, the privatization of the socialist housing sector the creation of a functioning tax system to reduce corruption ${ }^{26}$. Even though there is relative personal freedom, there are still human rights violations, discrimination against minorities, religions, violent repression of demonstrations, and imprisonment of dissidents ${ }^{27}$. There is censorship of the media; the state regulates access to the Internet. As stated by Ringen, the Communist Party of China is a state party that has its own strict selection rules and can only be accessed by really highly qualified people $^{28}$. Today, it is home to the best-known top executives of successful companies and enterprises, as well as financiers and wealthy people who are already buying up entire multinational companies in Europe and around the world. Their members are also rural teachers, dignitaries, but also scientists. As the party's policy and the state are identical, its primary goal is to maintain the stability of the state and increase economic growth.

The Chinese governance model has enormous advantages over the regime in force in the Slovak Republic and other states with a similar establishment. In the Slovak Republic, the Chinese model of governance, which combines the strengthening of the market economy with authoritarian governance, has not yet met with admiration.

The distorted notion in the Slovak Republic is that governance in the People's Republic of China is a socialist,

26 S. Ringen, Perfektní diktatura Čína ve 21. století, Prague 2018, p. 264.

27 I. Bakešová, O. Kučera, M. Lavička, Dějiny čínske lidové republiky (1949-2018), Prague 2019, p. 444.

28 S. Ringen, op.cit. 
communist dictatorship, which is not entirely true, as it is a state-run market economy focused on economic growth throughout the country. As stated by Midler, it is not a "Chinese game" but a real economic growth in contrast to the Slovak Republic, where economic games are often used, which artificially reduce the indicators of economic growth, e.g., unemployment ${ }^{29}$.

The management of the state in the People's Republic of China is in the hands of qualified people, where the condition is education, expertise, experience ${ }^{30}$. On the contrary, in the Slovak Republic, this condition refers to democracy, in which every citizen has the right to govern the state through the electoral system, there is no requirement of expertise, education, and experience. In 2014, the Polis Slovakia agency conducted a telephone survey on a sample of 1,052 respondents, older than 18 years, throughout the Slovak Republic. Citizens assessed the competence and knowledge of politicians. The results of the survey found that two-thirds of respondents do not consider politicians to be skilled. Although there are personalities with sufficient competencies and insight among them, the overall picture of political life is different. Members make decisions based on party affiliation, not on professional arguments. $90 \%$ of respondents consider it essential for politicians to increase their knowledge and competences, if they are supposed to be responsible for governance ${ }^{31}$.

29 P. Midler, Made in Č́na, Prague 2015, p. 269.

30 S. Ringen, op.cit., p. 111.

31 INESS - Institute od Economic and Social Studies, Politici, mali by ste sa vzdelávat', odkazujú občania https://iness.sk/sk/stranka/9999INESS-Politici-mali-by-ste-sa-vzdelavat-odkazuju-obcania [access: 10.10.2020]. 
As stated by Midler, China is a culture of imitation ${ }^{32}$. It is well known about China that it can imitate and produce anything within its sphere of production, so it is also in the political sphere, where what is good in the world and causes the country's economic growth is taken over in China, adapted to Chinese political conditions and consequently it will help the whole country. This thinking should also be transformed into the politics of the Slovak Republic. What we see as good in the world works and causes economic growth to adapt, thus ensuring the development and growth of the country.

In the People's Republic of China, legislation punishing violations is more rigid, and therefore compliance is higher. As stated by Hebnar, there are 55 crimes in China for which the accused faces the death penalty ${ }^{33}$. Among them are crimes of an economic nature, such as fraud or embezzlement. In the Slovak Republic, fraud and embezzlement are time-barred, which are pointed out will be forgotten over time, or the accused will serve for a few years and may continue to do so after serving.

Management in the People's Republic of China is mandatory, while in the Slovak Republic, it is voluntary. For this reason, the state cannot function unless it regulates the obligation, as there are elements of voluntariness that negate the obligations of the state and which everyone approaches after their so-called democratic approach. The difference between obligation and voluntariness in the processes set by the state is that when it comes to the basis of voluntariness, citizens do not comply with these obligations. Thus

32 P. Midler, op.cit.

33 J. Hebnar, Obchod s Čínou bez rizika a se ziskem, Prague 2016, p. 213. 
the state does not meet the goals it has set in its plans (budget, levies, tax collection). According to a survey conducted by the Polis Slovakia agency in 2014, the public administration in Slovakia has long suffered from the inability to set measurable goals and adjust expenditure policies adequately to achieve them. Such a situation causes dissatisfaction because its solution is either a constant increase in taxes or failure to achieve the desired goals. In this way, politicians also contribute to the low quality of public services, which discourages them from paying taxes ${ }^{34}$.

\section{Conclusion}

In the last thirty years, the People's Republic of China has embarked on a path of reform and opening up to the world, building socialism with Chinese characteristics. We can state that the People's Republic of China is not a capitalist country, nor is it a typically socialist country. It is a country in a transitional stage. The Communist Party remains the leading political force and creates a new modern society characteristic of the 21 st century based on its historical conditions. As several authors have said, the more we allow China to open up to the world and let it into the world, the more the world will give China freedom.

The Slovak Republic has also undergone significant political developments. In the period 1950-1989, there was a centrally managed planned economy in the territory of the Czechoslovak Republic, and an authoritarian political sys-

34 INESS - Institute od economic and social studies, Politici, mali by ste sa vzdelávat', odkazujú občania, https://iness.sk/sk/stranka/9999INESS-Politici-mali-by-ste-sa-vzdelavat-odkazuju-obcania [access: 10.10.2020]. 
tem prevailed. After the fall of the communist government in 1989, the first free parliamentary elections took place, and a Government of National Understanding was established. In 1990, after the fall of the communist regime, they began to lay the foundations of democracy. In the second half of the 20th century, the Slovak Republic also underwent extensive reforms that pursued several basic goals. In addition to increasing economy and efficiency in the public sector, decentralization and modernization of public administration have become such goals. The question is whether the reformed democratic system of the Slovak Republic serves the interests of ordinary citizens? We call ourselves de-democracy, and our political leaders boast that they are ordinary people, but is that so?

The paper's aim was based on the theoretical background to apply selected elements of governance of the People's Republic of China to streamline the management of public administration in the Slovak Republic.

In a large billion-dollar China, it has been proven that political governance should be in the hands of educated people with experience and qualifications in the field and not to favor democracy and the Constitution, because if there are freely elected citizens in management positions who do not have these preconditions, the whole our country. Therefore, one of the selected elements of management is in the right place to demand expertise and qualifications and not just political affiliation. Otherwise, we are just wasting time and slowing down the country's economic growth.

Just as China is not ashamed of imitating other countries and taking from them functioning and proven elements of success and growth, so our country should not only learn from its own mistakes but open itself up to the world and 
adopt successful governance models, whether political or economic for economic growth and increasing population's well-being.

Last but not least, in a legal and democratic state, it is fitting that the elements of governance are based on duty and not voluntary, as is the case in China, and it is, therefore, necessary for the duty to be enforced or enforced to be punished. Otherwise, the law in such a state has no weight, and it is a so-called unenforceability of the law.

In conclusion, it can be stated that if the selected elements of the management of the People's Republic of China were transferred at least partially to the management system of the Slovak Republic, it would be significantly streamlined, and the goal of the contribution was met.

\section{Bibliography}

Barrett E.J., The Role of Public Opinion in Public Administration, "The Annals of the American Academy of Political and Social Science" 1995, no. 537.

Bakešová I., Kučera O., Lavička M., Dějiny čínske lidové republiky (1949-2018), Prague 2019.

Brown A., Vzestup a pád komunismu, Brno 2011.

Bútorová Z., Gyárfášová O., Trendy vo verejnej mienke a voličskom správaní, [in:] Slovenské volby 2010. Šanca na zmenu, eds. Z. Bútorová et al., Bratislava 2011.

Callick R., Čas strany, aneb, Kdo a jak řídí Čínu, Prague 2015.

Cirner M., Polačková A., Ideologie jako součást politickoadministrativních korelací ve veřejném aparátu, [in:] MMK 2012. Mezinárodní Masarykova konference pro doktoran- 
dy a mladé vědecké pracovníky: sborník příspěvků $z$ mezinárodní vědecké konference, Hradec Králové 2012.

Čáky M., Činske súvislosti, Dunajská Streda 2011.

Hebnar J., Obchod s Cínou bez rizika a se ziskem, Prague 2016.

Liščák V., Dejiny Číny, Taiwanu a Tibetu v datech, Prague 2008.

Midler P., Made in Čína, Prague 2015, p. 269.

Nemec J., Po desiatich rokoch transformácie, "Ekonomický časopis" 2001, vol. 49, no. 4.

Oravec J., Liberalizácia ekonomiky a deetatizácia spoločnosti, [in:] Slovensko: desat' rokov samostatnosti a rok reforiem, eds. O. Gyárfášová, G. Mesežnikov, Bratislava 2004.

Morvay K., Kolektív A., Transformácia ekonomiky: skúsenosti Slovenska, Bratislava 2005.

Ringen S., Perfektni diktatura Č́na ve 21. století, Prague 2018, p. 264.

Slobodník M., Od posedného cisára k Maovi - dramatické premeny Číny v 20. storočí, "Historická revue" 2012, no. 7. Vykoupilová H., Víceúrovňové vládnutí v Evropě: koncepce, modely, typy, [in:] Viceúrovňové vládnutí v Evropě: zkušenosti, problémy a výzvy, eds. B. Dančák, V. Hloušek, Brno 2007.

Žárska E., Černěnko T., Kozovský D., Verejná správa. I, Bratislava 2010, p. 176.

\section{Internet sources}

Embassy of the People's Republic of China, Political system and structure of state bodies, http://sk.chineseembassy. org/slo/ss/oc/t364423.htm. 
Podstavek M., Politics and diplomacy, China, http://www.1sg. sk/www/data/01/projekty/2010_2011/neptunes/cina/ PD\%20Podlinky/PDpodlink2.html.

State Council, People's Republic of China, http://english. www.gov.cn/.

Lawrence S.V., Martin M.F., Understanding China 's Political System, Congressional Research Service Report for Congress, March 20, 2013. p. 7, https://www.fas.org/sgp/ crs/row/R41007.pdf.

en.people.cn, Constitution of the People's Republic of China, http://en.people.cn/constitution/constitution.html.

Noviny S.K., Nikdy sme nemali tol'ko slobody a zároveň tol'ko neistoty, tvrdi Radičová, https://www.noviny.sk/484291nikdy-sme-nemali-tolko-slobody-a-zaroven-tolkoneistoty-tvrdi-radicova.

INESS - Institute od economic and social studies, Politici, mali by ste sa vzdelávat', odkazujú občania, https://iness.sk/sk/stranka/9999-INESS-Politici-mali-by-ste-savzdelavat-odkazuju-obcania.

SLOV-LEX právny a informačný portál, Zákon č. 55/2017 Z.z. o štátnej službe a o zmene a doplnení niektorých zákonov, https://www.slov-lex.sk/pravne-predpisy/SK/ ZZ/2017/55/20200526.

\section{Legislation}

Constitution of the Slovak Republica Constitution of the People's Republic of China Act no. 55/2017 Coll. on Civil Service and on Amendments to Certain Acts 


\begin{abstract}
Public administration, as the administration of public affairs, is an administration acting in the public interest and the entities that implement it due to a legally imposed obligation resulting from their status as public entities. A person meets the public administration on a daily basis, either as a citizen of a specific state department or as a resident of a municipality. The final state of the public administration system cannot be achieved as it is constantly subject to various qualitative and quantitative changes. The aim of the paper is based on theoretical background to apply selected elements of governance of the People's Republic of China to streamline the management of public administration in the Slovak Republic. Sources of information are based on available sources of scientific and professional literature of domestic and foreign authors and other materials presenting theoretical and practical knowledge in the field of public administration in the Slovak Republic and the People's Republic of China. If selected elements of the governance of the People's Republic of China were transferred at least partially to the governance of the Slovak Republic, it would be primarily made more effective without elements of corruption, clientelism and political influence.
\end{abstract}

Keywords: public sector, public administration, management of public administration, public policy of the state, governance, marketing management, specifics of management

\begin{abstract}
Abstrakt
Administracja publiczna zajmuje się organizacją życia publicznego, dlatego jest typem urzędu działającego w interesie publicznym oraz zbiorem jednostek wykonawczych, na których spoczywa obowiązek prawny wynikający z ich statusu. $\mathrm{Z}$ administracją publiczną każdy obywatel ma do czynienia codziennie, choć zwykle z różnymi organami wykonawczymi lub typami urzędów. Nie jest możliwe osiągnięcie ostatecznego kształtu administracji publicznej, gdyż nieustannie podlega ona rozmaitym zmianom wynikającym z czynników ilościowych i jakościowych. Cel niniejszego badania opiera się na tle teoretycznym, zakładającym implementację wybranych mechanizmów zarządzania Chińskiej Republiki Ludowej w administracji publicznej Republiki Słowacji. Do przeprowadzenia badania
\end{abstract}


wykorzystano opracowania, do których zaliczały się m.in. literatura naukowa i profesjonalna autorów krajowych i zagranicznych prezentująca teoretyczne i praktyczne osiągnięcia w dziedzinie badań nad administracją publiczną w Republice Słowacji i Chińskiej Republice Ludowej. Gdyby wybrane mechanizmy zarządzania Chińskiej Republiki Ludowej zaimplementowano przynajmniej w części do procesów zarządzania w Republice Słowacji, ta druga stałaby się bardziej efektywna ze względu na wyeliminowanie korupcji, klientelizmu i politycznego wpływu.

Słowa kluczowe: sektor publiczny, administracja publiczna, zarządzanie administracją publiczną, polityka publiczna państwa, rządzenie, marketing i zarządzanie, specyfika zarządzania 


\section{Martin Molčan}

University of Ss. Cyril and Methodius in Trnava, Slovakia

\section{Andrea Čajková}

University of Ss. Cyril and Methodius in Trnava, Slovakia

ORCID ID: https://orcid.org/0000-0002-5951-1281

\section{Management of Territorial Self-Government in the Slovak Republic in Comparison with Management of Territorial Self-Government in the People's Republic of China and Possibilities of Its Efficiency in the Slovak Republic ${ }^{1}$}

\section{Introduction}

Public administration is an important and inseparable part of the mechanism ensuring the implementation and exercise of state or public power. Public authorities fulfill many public tasks and goals in various spheres and areas of everyday life.

The term "management in public administration" has the character of a subjective-objective relationship, where the subject of management can be individuals or institutions. It is a purposeful regulatory activity of public administration entities, which is to guide the given processes to achieve

1 This research was funded by Cultural and Educational Grant Agency of the Ministry of Education, Science, Research and Sport of the Slovak Republic, grant number KEGA004/UCM-4/2018. 
the set goals. It is characteristic of regulatory management activities that they are based on obtaining information that the managing entity obtains based on feedback. Feedback provides information on the course of implemented processes, where the managing entity compares the achieved results with the set goals and their indicators.

The need for the more efficient functioning of public administration stems from the need for its modernization. The content of the modernization of public administration is such a change that leads to a substantial qualitative change in functioning, higher performance, and growth of quality of work so that at a qualitatively higher level satisfies the requirements in terms of public interest, which are imposed on public administration.

Resources are needed to meet public needs and the functioning of public administration. Profitability and loss data are important information needed for financial management and performance measurement. It also applies to public sector institutions. Savings in the public sector are the result of rational measures that lead to greater efficiency and effectiveness.

The analysis focuses on examining the problem of management and finding appropriate methods, approaches, and procedures to apply the changes in the practice of public administration in the Slovak Republic.

The paper aims to focus on comparing local government management in the Slovak Republic and management in the People's Republic of China and selecting those aspects that would contribute to its streamlining in the Slovak Republic. 


\section{Territorial Government and Its Governance in the Slovak Republic}

Public administration reform has been underway in the Slovak Republic since 1990. This year, the foundations were laid for a new, democratic model of public administration. The philosophy of the whole reform was the decentralization of public administration. The concept of decentralization and modernization of public administration aimed to eliminate the shortcomings of centralized management of state administration. An important component of public administration is self-government.

As stated by J. Kútik and R. Karbach, the origin and development of self-government are associated with the formation of civil society, i.e., a company that is outside the direct influence of state power ${ }^{2}$. Territorial self-government is the self-governing administration of public affairs in a smaller territory than the state territory, based on the statutory scope and economic conditions, which streamline solutions to citizens' problems, as they are closer to them and relate to specific regional territories. The precondition for the functioning of territorial self-government is to ensure the inviolability of its power.

As stated by A. Krunková, territorial self-government represents precisely in connection with the principle of democracy the basis of democratic construction of the state in sequence citizen territorial self-government, the state,

2 J. Kútik, R. Karbach, Systémy verejnej správy, Bratislava 2011, p. 204. 
rightly we can consider it as one of the essential features of the modern democratic rule of law ${ }^{3}$.

Territorial self-government is carried out at the municipality's inhabitants assemblies, by a local referendum, a referendum on the territory of a higher territorial unit, municipal bodies, or bodies of a higher territorial unit.

According to Art. 64 of the Constitution of the Slovak Republic form the territorial self-government of a municipality and higher territorial units. Under the conditions established by law, the municipality is a legal entity that independently manages its property and income. The higher territorial unit is an independent territorial self-governing and administrative unit.

Based on data from the Statistical Office of the Slovak Republic, 2890 municipalities were registered in the Slovak Republic as of 31.01.2020 ${ }^{4}$. The concept of self-government at the municipal level in the Slovak Republic considers elements of direct democracy. According to Art. 67 of the fourth chapter of the Constitution of the Slovak Republic, the municipality's inhabitants may exercise self-government through their elected representatives or directly.

The bodies of the municipality are made up of elected bodies, which are the municipal council and the mayor of the municipality, as well as executive bodies, which are the municipal office and the head of the municipal office. The municipality's representative and its highest executive body is the mayor of the municipality. He represents the munici-

3 A. Krunková, Verejná moc a priama demokracia, Košice 2010, p. 139.

4 DATACUBE, Statistical Office of the Slovak Republic, Počet obcí a miest, http://datacube.statistics.sk/\#!/view/sk/VBD_SK_WIN/om3002rr/v_om3002rr_00_00_00_sk [access: 8.10.2020]. 
pality before state bodies to other municipalities and other legal and natural persons.

The organization of the municipal office consists of the municipal administration department, with economic, tax, regions and registries, organizational and social affairs, protection of persons and property, education, culture and sports, and the environment and municipal property department with environmental, exhibition and building regulations, operation and maintenance.

Under the conditions established by law, a municipality is a legal entity that independently manages its property and financial resources. The municipality has the right to associate with other municipalities to ensure matters of common interest. The basic role of the municipality in the performance of self-government is to take care of the all-round development of its territory and the needs of its inhabitants. Municipalities may be imposed obligations and restrictions in the exercise of self-government only by law and based on an international agreement. The municipality finances its needs primarily from its revenues, state subsidies, and other sources.

Decentralizing territorial self-government, which transferred responsibility from the state to higher territorial units and municipalities, did not bring the desired effect due to an ineffective mutual control mechanism. The original idea was to transfer the competences of local government management closer to the citizen. However, effective, control feedback is absent, as the allocated resources to which the local government is entitled are not used economically and efficiently.

As stated by E. Žárska, T. Černěnko, and. D. Kozovský, a large range of competencies also means a large range of 
assets and financial resources for their provision, which can be a space for uneconomical handling of it up to corrupt behavior. At present, the control of the municipality's activities is ensured through the chief controller of the municipality, who regulates the creation, structure of the budget and limits its indebtedness. The non-involvement of citizens by local self-government is one serious problem. The other is the lack of interest of the citizen to participate ${ }^{5}$.

Suppose a local government is to function effectively. In that case, it must be managed so that the set goals are achieved and the resources expended are used economically and efficiently. The key precondition for effective management performance in territorial self-government is appropriately set goals with clearly defined indicators. The meaning of all management activities is focused on monitoring objectives, monitoring their indicators, adopting corrective measures, and implementing regulatory activities to ultimately achieve the set objectives. Then we talk about effective management. Achieving the quality and efficiency of the performance of territorial self-government presupposes professional and highly qualified management.

The modernization of territorial self-government is a step contributing to its streamlining. It is a controlled change, which in itself has a qualitative character, and such a change contributes in the overall summary to the final change in the quality of the functioning of the entire system of territorial self-government.

5 E. Žárska, T. Černěnko, D. Kozovský, Verejná správa. I, Bratislava 2010, p. 176. 


\section{Territorial Government and Its Governance in the People's Republic of China}

At the time of the founding of the People's Republic of China, districts were the basic unit at the district administration level. Its superior unit is usually one of the city prefectures or another unit at the prefectural level.

Historically, the districts belong to the traditional Chinese administrative units established during the war states. After the unification of China by the Qing dynasty in 221 $\mathrm{BC}$., the empire was divided into commanders and those into about 1300 districts. In the next two millennia, the district offices remained the lowest state administration offices, under which local self-government and the informal influence of the gentleman functioned.

In 1949, the People's Republic of China was divided into six large territorial units that still stood above the provincial levels: the northern, northeastern, northwestern, eastern, southern, and southwestern regions. These provinces were abolished in 1955 and assigned to the respective provinces ${ }^{6}$.

Until the beginning of the $20^{\text {th }}$ century, the number of districts did not change significantly, fluctuating between 1100 and 1400 . At the end of 2005, there were 1464 districts in the People's Republic of China. By 2014, the number of districts decreased to 1425 . The mission of reducing the number of municipalities within the territorial administrative reform was to weaken the influence of self-government in the lowest units - municipalities. The main principle was merging municipalities into associations of four to five

6 I-Wu Liao, Hovory se spodinou, Prague 2013, p. 360. 
municipalities, which subsequently choose their self-government bodies. The main reason for the merger was the number of settlements and not the decisive family clans until then. The importance of family clans in the public sphere has thus been minimized.

At present, the People's Republic of China has a threetier administrative system:

- provinces, autonomous regions, and self-governing cities directly subordinate to the government,

- provinces, autonomous regions, and large cities directly subordinated to the government are further subdivided into autonomous prefectures, districts, autonomous districts, and cities,

- districts and autonomous districts resp. prefectures are further divided into towns and villages, including towns and villages of ethnic minorities.

All autonomous regions, autonomous prefectures, and autonomous districts are ethnically autonomous units. The Constitution explicitly empowers state authorities to establish special administrative areas if necessary.

The People's Republic of China is a unified multi-ethnic country with 56 ethnic groups. The basic principles of the Government of the People's Republic of China in regulating inter-ethnic relations are equality, unity, mutual assistance, and common prosperity. These principles are also enshrined in the Constitution of the People's Republic of China, which has made it possible to establish a system of autonomous regions with the relevant local authorities ${ }^{7}$. In addition to the five autonomous regions, the People's Republic of China has

7 Constitution of the People's Republic of China, http://en.people.cn/ constitution/constitution.html. 
80 autonomous prefectures, 120 autonomous districts or "battalions", and more than 1,300 local ethnic communities.

Autonomous authorities of the Autonomous Communities enjoy a wide range of rights that go beyond the powers of other public authorities at the same level. They have the right to control, collect taxes, and make independent decisions about local construction, education, science, culture, health, and other local matters. The central government provides them with great help in upgrading the qualifications of persons belonging to national minorities. It has set up many universities and colleges in Autonomous Communities. He also regularly provides them with great financial and material assistance ${ }^{8}$.

\section{Comparison of the Management of the Territorial Self-Government in the Slovak Republic with the Management of the Territorial Self-Government in the People's Republic of China and the Possibilities of Its Efficiency in the Slovak Republic}

At present, the territorial and administrative division of Slovakia consists of eight self-governing regions (higher territorial units).

This breakdown is often criticized, as it would be quite sufficient if there were only three to four of them (as in the past) to ensure the tasks of local public administration, and such a breakdown would be more economical and efficient. In support of the criticisms made, it can be stated that:

8 Embassy of the People's Republic of China, Political system and structure of state bodies, http://sk.chineseembassy.org/slo/ss/oc/t364427. htm [access: 8.10.2020]. 
- already for three regional units, their territories could have the so-called Aronded shapes, i.e., those in which their peripheral parts would not have to be significantly different distances from their centers (in contrast to the relatively elongated shape of the territory of Slovakia),

- in terms of terrain, according to the physical geography, there are relatively significant differences between essential lowland western Slovakia, mountainous central Slovakia, and hilly eastern Slovakia,

- from the linguistic point of view, there are three basic groups of Slovak dialects - West Slovak, Central Slovak, and East Slovak.

Map of the division of self-governing regions of the Slovak Republic

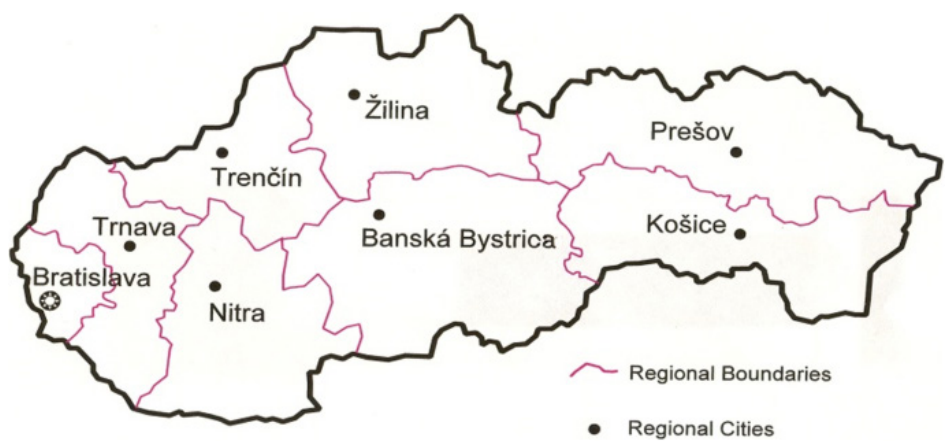

Source: http://www.reed.edu/economics/parker/201/cases/unemp_in_ SK.html.

The European Union (EUROSTAT) also divided the territory of Slovakia into only four so-called NUTS II - National units of territorial statistics (Bratislava region, Western Slovakia, Central Slovakia, and Eastern Slovakia) essential for distributing funds from the European Union. 


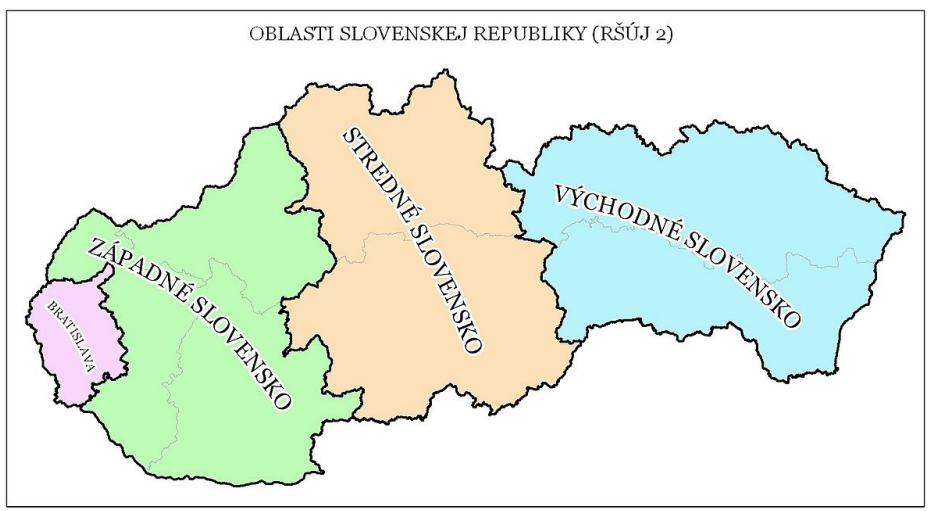

Source: https://commons.wikimedia.org/wiki/File:RSUJ2.jpg.

In addition, it may be added that the division of Slovakia into three to four regional units has already occurred in the past (Josephine districts, districts, and departments of the Hungarian governorate under Bach's absolutism and subsequent years, and especially the relatively recent division from the last period of former Czechoslovakia in 1961-1990, the functioning of which is still vividly remembered by a large part of the population and, in particular, by competent representatives.

Reducing the number of higher territorial units from eight to three to four would ensure greater efficiency and economy, especially in the costs of public finances spent on their operation and functioning.

A comparison with the People's Republic of China states that more than 1.4 billion people currently live in China, making it the most populous country globally. With this population and China's territorial division, it consists of 23 provinces, five autonomous regions (Guangxi, Inner Mongolia, Ningxia, Xinjiang, and Xi'an known as Tibet), four 
municipalities (Beijing, Chunking, Shanghai, and Tiananmen), and two special administrative regions, Hong Kong and Macao. Taiwan is considered the $23^{\text {rd }}$ Chinese province, although it has a partially independent administration.

Managing local government in China to unite communities and reduce settlements to prevent familyhood (family clan decision-making) proves to be more efficient and costeffective.

In Slovakia, the reduction of higher territorial units from eight to three to four and merging individual municipalities brought about the elimination of familyhood and community management, which is most pronounced especially in eastern Slovakia.

Another aspect of local government management in the People's Republic of China is that the autonomous authorities have the right to control, collect taxes, and make independent decisions about local construction, education, science, culture, health, and other local matters. On the contrary, in the Slovak Republic, the tax system is centralized, and taxes on natural and legal persons are collected through the tax office centrally to the state budget. The territorial administration decides and has only selected real estate taxes. In the case of taking over the tax collection model from the People's Republic of China, the local government in Slovakia could collect and administer collected corporate and personal taxes, which would ensure better and more efficient tax collection closer to the citizen, which is the goal of the entire public administration. In this way, greater respect for individual taxpayers would be ensured, stimulating their motivation to be a proud, responsible and honest taxpayer than in the past. For instance, in the 1990s, every citizen wanted to be a self-employed entrepreneur, 
as it meant prestige and higher social status than to be just a regular employee.

\section{Conclusion}

Public administration is an activity performed by state administration bodies, self-government bodies, and public institutions in the performance of public tasks. Its main objective is to operate the public good through the strengthening of civil society and social justice.

Territorial self-government is a part of public administration, usually in issues of local significance, which is carried out not by the state but by the population of territorial units or certain bodies of territorial units.

Territorial self-government undoubtedly deserves to be described as one of the most important foundations and an integral part of a democratic society. From a historical point of view, this is a relatively old institute, which has been experiencing its renaissance since the 19th century, when society began to rediscover and return to proven values.

The idea of territorial self-government is inextricably linked to the idea of civil society. Self-government can exist and function effectively only in a democratic state governed by the rule of law based on a plurality of social and political interests. It is based on the idea of a kind of partnership, cooperation between the state and territorial self-governing corporations as subjects of self-government.

Suppose a local government is to function effectively. In that case, it must be managed so that the set goals are achieved and the resources expended are used economically and efficiently. 
The paper aimed to focus on comparing local government management in the Slovak Republic and management in the People's Republic of China and selecting those aspects that would contribute to its streamlining in the Slovak Republic.

One of the selected aspects of the management of territorial self-government in the People's Republic of China, which would contribute to the streamlining of the management of territorial self-government in the Slovak Republic, is the reduction of the number of higher territorial units. In China, the world's most populous country with 23 provinces, five autonomous regions, and four municipalities, the goal is to constantly merge municipalities and reduce settlements. In Slovakia, the reduction of higher territorial units from eight to three to four and merging individual municipalities brought about the elimination of familyhood, community management, which proves to be more efficient and economical.

Another selected aspect of the management of territorial self-government in the People's Republic of China, which would contribute to the streamlining of the management of territorial self-government in the Slovak Republic, is the adoption of a tax collection model that would be better and more efficient, closer to the citizen, which is also the goal of the whole public administration.

The modernization of territorial self-government is a step contributing to its streamlining. It is a controlled change, which in itself has a qualitative character, and such a change contributes in the overall summary to the final change in the quality of the functioning of the entire system of territorial self-government.

If public administration is to function effectively, it must be managed so that the set goals are achieved and the resources expended are used economically and efficiently. 
Success is the repetition of things that work well and not take the path of trial and error. The goal of the post has been met.

\section{Bibliography}

Krunková A., Verejná moc a priama demokracia, Košice 2010, p. 139.

Kútik J., Karbach R., Systémy verejnej správy, Bratislava 2011, p. 204.

Liao I-Wu, Hovory se spodinou, Prague 2013, p. 360.

Žárska E., Černěnko T., Kozovský D., Verejná správa. I, Bratislava 2010, p. 176.

\section{Internet sources}

DATACUBE, Statistical Office of the Slovak Republic, Počet obci a miest, http://datacube.statistics.sk/\#!/view/sk/ VBD_SK_WIN/om3002rr/v_om3002rr_00_00_00_sk.

Embassy of the People's Republic of China, Political system and structure of state bodies, http://sk.chineseembassy. org/slo/ss/oc/t364427.htm.

http://www.reed.edu/economics/parker/201/cases/unemp_ in_SK.html

https://commons.wikimedia.org/wiki/File:RSUJ2.jpg.

SLOV-LEX právny a informačný portál, Zákon č. 302/2001 Z.z. o samospráve vyšších územných celkov (zákon o samosprávnych krajoch), https://www.slov-lex.sk/pravnepredpisy/SK/ZZ/2001/302/20200409.

\section{Legislation}

Constitution of the Slovak Republic Constitution of the People's Republic of China 
Act no. 302/2001 Coll. on the self-government of higher territorial units (Act on self-governing regions)

\begin{abstract}
Territorial self-government is a part of public administration, usually engaged in local issues, which is carried out not by the state but by the population of territorial units and certain bodies of territorial units. Territorial self-government is a spatially defined functional unit that has the right to decide on its affairs. The basis of territorial self-government is the municipality. The municipality is the basic territorial unit of the state. The paper aims to focus on comparing local government management in the Slovak Republic and management in the People's Republic of China and selecting those aspects that would contribute to its streamlining in the Slovak Republic. The information obtained comes from the analysis of secondary sources. The analysis focuses on examining the problem of management and finding appropriate methods, approaches, and procedures to apply the changes in the practice of public administration in the Slovak Republic. If public administration is to function effectively, it must be managed so that the set goals are achieved and the resources expended are used economically and efficiently.
\end{abstract}

Keywords: mayor of village, communication, citizen, public administration, territorial self-government

\begin{abstract}
Abstrakt
Samorząd terytorialny jest częścią administracji publicznej i zazwyczaj zaangażowany w sprawy o znaczeniu lokalnym. Jego zadania wykonywane są przez populacje jednostek terytorialnych oraz organizacje regionalne. Samorząd terytorialny jest ponadto jednostką przestrzenną o charakterze funkcjonalnym, posiadającą kompetencje i prawa niezbędne do podejmowania decyzji o samym sobie. Podstawą tworzącą samorząd terytorialny jest gmina, będąca elementarną jednostką terytorialną państwa. Celem badania jest porównanie mechanizmów zarządzania samorządu terytorialnego w Republice
\end{abstract}


Słowacji i Chińskiej Republice Ludowej, a następnie wybór spośród nich takich, które można z powodzeniem przenieść z gruntu azjatyckiego na europejski. Dane badawcze zaczerpnięto $\mathrm{z}$ analiz dostępnych w źródłach wtórnych. Badanie skupia się na analizie zarządzania oraz znalezieniu właściwych metod, podejść i procedur, które mogłyby posłużyć do wprowadzenia korzystnych zmian dla funkcjonowania administracji publicznej w Republice Słowacji. Jeżeli administracja publiczna ma funkcjonować efektywnie, musi być zarządzania w taki sposób, aby wyznaczane przez nią cele były realizowane, a zasoby przeznaczone na ten cel były wykorzystywane ekonomicznie i wydajnie.

Słowa kluczowe: wójt, komunikacja, obywatel, administracja publiczna, samorząd terytorialny 


\author{
Marceli Burdelski \\ Wroclaw University \\ Asia Pacific Society Poland \\ Research Commitee 42: Integration, Unification, Security \\ of International Political Science Association
}

\title{
Impact of External and Internal Challenges for Political System and Economy of North Korea
}

In my paper I try to explain political and economic strategy of Kim Jong Un and North Korean leadership in 2020. DPRK strategy is still far from state and party founder Kim Il Sung's death. The strategy is to survive in the changing world. In the end of the 1990s, a top diplomat in DPRK Embassy in Warsaw said: "The whole world has changed, but we did not". This is the source of our problems. An ideologically, politically, and economically unique system must be total and isolated.

Some rules of DPRK's strategy are still valid:

1. Securing power of Kim's dynasty. In North Korea there is the official theory of leaders succession ${ }^{1}$. North Korea's official ideology is based on Kimismus Juche (selfreliance). In November 2010, during a visit in North Korea, I met the deputy director of the International Department of Central Committee WPK. He said that

1 M. Burdelski, Wptyw procesu sukcesji na problem stabilizacji bezpieczeństwa narodowego Koreańskiej Republiki Ludowo-Sdemokratycznej (The Impact of succession process for national security stabilization of Democratic People's Republic of Korea), [in:] Implications for global security, ed. E. Jendraszczak, Warsaw 2017, pp. 113-133. 
the young leader Kim Jong Un has suitable knowledge, abilities, skills and competence, just like his father, and grandfather. North Korea looks for leaders in the category of mythology. Now, the position of Kim Jong Un is very strong, though some troubles undermine the leader's position. His speech on the $75^{\text {th }}$ Anniversary of WPK was an apology for economic troubles.

2. Continuing isolation. On January 28, North Korea closed airports and railway connections with China and Russia. The only exceptions were cargo flights, railway and truck transports with these countries. Special action was taken on China-DPRK border line. The stop for smuggling goods from China is an obstacle for local markets. Floods and two giant typhoons destroyed agriculture fields. Harvest this year is very poor. Food delivery from the Public Distribution System is cut half form 700 gram to 350 gram per day, thus rice substitutes grain. Isolation and lockdown caused problems to the UN Food Aid Agency. Increasingly more diplomats from western countries leave North Korea. Access to the Internet is limited even for high-rank political and military leaders of North Korea. The Embassy in Poland uses Internet via satellite telephone. The connection often is lost. Now in North Korea there are three million mobile telephones registered in Koryo link. Functions of mobile phones are very limited. There are only few North Korean connections through intranet. Diplomats and foreigners use other networks. Internal control of citizens is very strict. House committee control often checks flats for sanitary standards. After two years of maintaining good relations with South Korea, it was stopped. Kim Jong Un was afraid of South Korean pop-culture and lifestyle. 
3. Guaranteeing survival of North Korean regime through nuclear arms and missile programme development. This is North Korea's "life insurance policy". After freezing strategic dialogue with the US, North Korea made a step back to deterrence policy. It is "traditional" North Korea's policy (or tactic), resembling Lenin's “one step forward, two steps backward” approach. Kim Jong Un nominated two creators of the nuclear programme to marshal rank.

Now main challenges and threats for North Korea are:

1. Damages made by COVID-19 to North Korea North Korea used draconian and brutal methods to contain the coronavirus pandemic. Officially, in North Korea there had been no single one confirmed case of COVID-19. Only one defector from North Korea came back to his country with COVID-19. Then the official information was about 23 thousand people sent to a quarantine camp. Health Experts from abroad did not believe statistics given by North Korea. The state lacks hospitals and medical institutions. According to the John Hopkins University, the Health Security System Index puts North Korea on $193^{\text {rd }}$ out of 195 positions. North Korea rejected an aid offer from South Korea. Sanitary cordon around of North Korea reduced legal and illegal foreign trade. Trade with China is $95 \%$ of North Korea's trade volume. According to the opinion of prof. Kim Byoung, North Korea lost $\$ 1$ billion of reserves and its trade with China lowered to only 4\%. In February, North Korea limited tourism and using ski resorts. Now, North Korea is closed for foreign tourists even from China. The regime also stopped smuggling. Many small traders in local markets did not earn this year. It is a vital information because local markets have critical impact for North Korea GNP. 
Serious floods and giant typhoons have destroyed cities, villages, and agriculture fields in North Korea. Food security faces a severe crisis. Receiving external aid is very difficult. Lot of the UN aid agency officers must leave North Korea, even by force. According to the opinion of the Center Strategic and International Studies, food situation in North Korea is worse than in the mid 1990s. The UN sanctions have impacted the catastrophic food situation. 11 million DPRK citizens are malnourished. Kim Jong Un's dreams about North Korean reform to create market-oriented economy will be ruined. The coronavirus pandemic will create vast gap between South and North. North Korean GDP in 2019 was \$18 billion and going down in 2020. In the opinion of Sue Mi Terry, the UN sanctions and COVID-19 damages will be decreasing Kim Jong Un's position in negations with the US. In the speech on 75th anniversary, Kim Jong Un announced a new approach to South Korea. New North Korean ambassador to Poland, Choe Il, will send North Korean students to study chemistry in Poland. Thus, Poland maintains diplomatic activities in Pyongyang. Currently, there are two Polish diplomats: Charge d'Affairs Damian Mikołajczyk, and a secretary. Ambassador Choe Il gave a speech to the participants of the VII International Asian Congress in Torun.

China maintains its policy toward North Korea. Russia also will participate in future events on the Korean Peninsula. Japan, after the nomination of prime minister Suga, announced new proposals of policy toward North Korea.

The new President of the US also will adopt new policy toward the Korean Peninsula, probably kind and friendly alliance with the Republic of Korea and a pragmatic-realistic approach to North Korea. 


\title{
Conclusions
}

Observing the current situation in North Korea, we should be aware of several things:

1. COVID-19 and natural disasters pose challenges to North Korea.

2. Kim Jong Un's New Year's Speech for 2021 will cover North Korea's strategic goals and tactics.

3. Role of VIII Congress WPK in the regulation processes of Korean domestic and foreign policy.

4. How and when North Korea will go out from lockdown?

\section{Bibliografia}

Burdelski M., Wptyw procesu sukcesji na problem stabilizacji bezpieczeństwa narodowego Koreańskiej Republiki Ludowo-Sdemokratycznej (The Impact of succession process for national security stabilization of Democratic People's Republic of Korea), [in:] Implications for global security, ed. E. Jendraszczak, Warsaw 2017.

\begin{abstract}
In the paper I explain the impact of external and internal challenges for political and economic system of North Korea. 2020 was a breaking point for Kim Jong Un's leadership and development strategy. Under current circumstances, North Korean leadership is still a valid strategy to survive in the changing world. The paper identifies key aspects of North Korean politics.
\end{abstract}


1. Securing Kim's dynasty. 2. Maintaining North Korea's isolation. Limiting access to the Internet and other external media. Stopping exchange with South Korea. 3. Treating nuclear arms and missiles as "life insurance". Receiving every kind of aid and resources from international organizations and other countries.

Now the main threats for Kim Jong Un's leadership are:

1. Damage caused by COVID-19. Total isolation of North Korea since the end of January 2020 caused loss in profit coming from export to China and Russia. North Korea is closed even for foreign visitors. West European countries have evacuated even diplomatic personnel staying on missions.

2. Economic and personal sanctions imposed by the UN Security Council deepen the economic troubles. Food and health security levels in North Korea are unknown. Kim Jong Un now proclaims Ardous March.

3. Failing policy toward the United States, South Korea, and the European Union.

4. Natural disasters: flood in July and two giant typhoons that destroyed cities and villages on the West and East coasts.

In effect, economic plans associated with the $75^{\text {th }}$ Anniversary of Labor Party of Korea failed. An answer is expected to be given at the $8^{\text {th }}$ WPK congress in January 2021.

Keywords: North Korea, COVID-19, politics, economy

\begin{abstract}
Abstrakt
W pracy podjęto probe wyjaśnienia wpływu czynników zewnętrznych i wewnętrznych na system polityczny i ekonomiczny Korei Północnej. Rok 2020 był punktem zwrotnym dla przywództwa Kim Jong Una oraz jego strategii rozwoju państwa. W obecnych warunkach przywództwo Korei Północnej mimo wszystko wciąż jest skuteczną strategią przetrwania w zmieniającym się świecie. W pracy zidentyfikowano kluczowe zagadnienia aktualnej polityki wewnętrznej i zagranicznej Korei Północnej.

1. Zabezpieczenie sukcesji dynastii Kimów. 2. Podtrzymanie izolacji Korei Północnej. Ograniczanie dostępu do Internetu i innych mediów zewnętrznych. Zaprzestanie wymiany z Koreą Południową. 3. Traktowanie broni jądrowej jako "polisy ubez-
\end{abstract}


pieczeniowej". Otrzymywanie każdego rodzaju pomocy i zasobów od organizacji międzynarodowych oraz innych państw. Głównymi zagrożeniami dla przywództwa Kim Jong Una są:

1. Szkody wywołane przez pandemię COVID-19. Całkowita izolacja Korei Północnej od końca stycznia 2020 r. spowodowała straty w zyskach pochodzących z eksportu towarów do Rosji i Chin. Ponadto Korea Północna zamknęła się na wszystkich wizytujących z innych państw. Państwa Europy zachodniej ewakuowały stamtąd nawet personel misji dyplomatycznych.

2. Sankcje ekonomiczne i osobowe nałożone przez Radę Bezpieczeństwa ONZ zwiększają skalę problemów ekonomicznych Korei Północnej. Ponadto nieznane są poziomy bezpieczeństwa żywieniowego i zdrowotnego Korei Północnej. Kim Jong Un jest bliski ogłoszenia klęski żywieniowej.

3. Zawodząca polityka wobec Stanów Zjednoczonych, Korei Południowej i Unii Europejskiej.

4. Katastrofy naturalne: powódź w lipcu oraz dwa gigantyczne tajfuny zniszczyły wioski i miasta na wschodnim oraz zachodnim wybrzeżu.

W rezultacie plany ekonomiczne powiązane z 75 . rocznicą powstania Partii Pracy zawiodły. Uzyskanie odpowiedzi na ten stan rzeczy spodziewane jest podczas kongresu WPK, który odbędzie się w styczniu $2021 \mathrm{r}$.

Słowa kluczowe: Korea Północna, COVID-19, polityka, ekonomia 


\section{Wojciech Mincewicz}

University of Warsaw

ORCID ID: https://orcid.org/0000-0003-0460-9158

\section{Central Bank Digital Currency as an Implementation of Distributed Ledger Technology: Digital Yuan Case Study}

\section{Introduction}

Blockchains are nowadays a catalyst for change. They intensively affect the sphere of public authority, lifestyle, traditional models of corporate activity, society, and many institutions on a global scale. Blockchain technology is increasingly referred to as the most important invention since the inception of the Internet ${ }^{1}$. It is a mechanism that allows individuals to send a unique digital record without the risk of copying or the existence of a trusted third party. For several years now, the blockchain has been in the top ten of the list of the Council on New Technologies of the World Economic Forum in Davos, which prepares a list of the most disruptive technologies that have the greatest impact on improving the lives of societies, transforming other areas of the economy and protecting

1 J. De Silva, K. Parker, P. Broun, Blockchains - „The most importation since the internet itself', Murfett Legal Professionalism. Understanding. Results 2017, https://www.murfett.com.au/MurfettLegal/ media/Documents/Article/35-Blockchains-The-Most-Important-Invention-Since-the-Internet-Itself.pdf [access: 2.12.2020]. 
the environment ${ }^{2}$. Blockchain is sometimes referred to as the next, after the World Wide Web, trusted layer of the Internet ${ }^{3}$ or the Internet of values ${ }^{4}$. In practice, it is a distributed register operating in a peer-to-peer network, which is cryptographically secure, allows only adding data, is not modifiable, and is updated only based on consensus between its users ${ }^{5}$. A blockchain contains an ever-growing amount of information grouped into blocks and linked together so that each next one contains a timestamp when it was created and a link to the previous block, the hash, summarizing its content ${ }^{6}$.

Blockchain is increasingly used in other areas of human life. In 2008, it became the basis of the first Bitcoin cryptocurrency ${ }^{7}$. At that time, first-generation chains were used to create an electronic payment system that would eliminate the need for an intermediary guaranteeing the correctness and security of financial transactions. Since Satoshi Nakamoto announced and implemented his idea, two more generations have arisen. Blockchain 2.0 has found economic, market, and financial applications in services that go beyond

2 In 2019, Blockchain technology came in fifth on the list. Vide A. De Nisco Rayome, Innovation, TOP 10 emerging technologies of 2019, https:// www.techrepublic.com/article/top-10-emerging-technologies-of-2019/ [access: 2.12.2020].

3 W. Mougayar, The Business Blockchain: Promise, Practice and Application of the Nest Internet Technology, Hoboken 2016, pp. 30-36.

4 D. Tapscott, A. Tapscot, Blockchain Revolution: How the Technology Behind Bitcoin is Changing Monety, Business and the World, London 2016, p. 19; W. Szpringer, Blockchain jako innowacja systemowa: od internetu informacji do internetu wartości: wyzwania dla sektora finansowego, Warsaw 2019.

5 I. Bashir, Mastering blockchain, Birmingham 2017, pp. 16-17.

6 K. Piech, Leksykon pojęć na temat technologii blockchain i kryptowalut, Warsaw 2016, p. 5.

7 Vide S. Nakamoto, Bitcoin: A peer-to-peer Electronic Cash System, https://bitcoin.org/bitcoin.pdf [access: 02.12.2020]. 
simple money transactions such as bonds, futures, mortgage loans, title deeds, and smart contracts. The creation and development of the blockchain 3.0 means its use other than economic, related to, for example, use in state administration, health care, science ${ }^{8}$. The basis of subsequent generations is a distributed register ${ }^{9}$, and the information stored in it may therefore be diverse. The governments of individual countries became interested in the possibility of implementing blockchain relatively quickly, striving, among other things, to link the technology with their official money. Resilience to failures, hacker attacks, reliability, speed of operation, protection against fraud or crimes committed with the use of electronic tools - these are just some potential advantages of the system that have been noticed and are the basis for the design of the Central Bank's Digital Currency. The term was used for the first time in $2016^{10}$, but so far, no universally recognized, standardized definition has been developed. There is not even a leading pattern to follow when designing new solutions. In a broad descriptive sense, analyzing the etymological significance, Digital Currencies is a new form of widely available central bank money. CBDCs are regulated and issued by the monetary authorities of individual countries, which are also responsible for setting their face value ${ }^{11}$. Sometimes CBDCs are combined with stabelcoins, which is not justified and is a mistake. The Digital

8 M. Swam, Blockchain: Blueprint for a New Economy, Newton MA 2015, p. ix.

9 More on the distributed ledger later in this work.

10 J. Barrdear, M. Kumhof, The Macroeconomics of Central Bank Issued Digital Currencies; Technical Report 605; Bank of England, London 2016.

11 Vide A. Kriwoluzky, Ch. Huun Kim, Monetary Dialogue Papers: Public or Private? The Future of Money, Luxembourg 2019, p. 17. 
Currency of the Central Bank, as the name suggests, is to be a digital form of money issued by a central state banking institution. Stablecoins, on the other hand, remain constant in value by indexing 1 to 1 with some underlying asset (US dollar, gold), but the originators, sole issuer, and creators are a private company. Therefore, they have a different legal status than the official digital fiat currency.

The article aims to analyze the concept of digital money of central banks on the example of the Digital Yuan. In the first place, the most important premises for undertaking work on creating a digital banking money system and the discussed projects that contributed to the increased dynamics of development were indicated. For several years, intensive work on solutions that would ultimately lead to creating a digital form of government money has been carried out in Russia or Sweden. It seems, however, that the most advanced works are carried out by the People's Bank of China (PBOC), i.e., the central bank of the People's Republic of China, which is the closest to implementation. Efforts in 2020 have been intensified as the need for a contactless payment system has increased in the wake of the coronavirus epidemic ${ }^{12}$. The Middle Kingdom provides a case study for the following article. The potential opportunities and threats resulting from the dissemination of CBDC were analyzed. An important variable to consider is the undemocratic political regime in China, an inherent part of which is total control over its citizens. The study uses the analysis of central bank documents of individual countries and reports of international institutions and press materials.

12 R. Auer, G. Cornelli, J. Frost, Covid-19, Cash, and the Future of Payments; Technical Report; Bank for International Settlemens, Basel 2020. 


\section{Central Bank Digital Money - Concept Outline, Reasons for Undertaking Work}

Advances in cryptography and distributed ledger technology make digital currencies widely used, also by Central Banks. The introduction and dissemination of CBDC can constitute a historic innovation in money and banking and ultimately lead to realizing the so far utopian vision of a cashless society ${ }^{13}$. In addition to the potential exclusion from the circulation of physical cash, CBDC will allow central banks to increase control over money circulation by permanently mediating all exchange transactions. Among the features that distinguish $\mathrm{CBDC}$ from traditional cash and cryptocurrencies, the most frequently mentioned are: universal character, 24/7 electronic access to funds and denomination in the national currency, which ensures, at least in theory, exchange rate stability ${ }^{14}$. The idea of using blockchain technology by state institutions was developed along with its growing importance and the evolution of its next generations. Petro seems to be extreme and, at the same time, classic, the value of which was to be based on the reserves of Venezuela's crude oil ${ }^{15}$. Petro was supposed to be a response to the hyperinflation of the bolivar - the country's national currency. The undemocratic regime of Nicolas

13 Vide N. Fabris, Cashless Society-The Future of Money or a Utopia?, „Journal of Central Banking Theory and Practice” 2019, vol. 8, no. 1, pp. 53-66.

14 J. Barrdear, M. Kumhof, op.cit., p. 7.

15 B. Chappell, Venezuela Will Create New 'Petro' Cryptocurrency, President Maduro Says, NPR, https://www.npr.org/sections/thetwo-way/2017/12/04/568299704/venezuela-will-create-new-petro-cryptocurrency-president-maduro-says [access: 5.12.2020]. 
Maduro, as well as the only declarative link to the price of the raw material ${ }^{16}$, means that the digital token guaranteed by the Venezuelan government has not gained any real significance.

Each country considering implementing the digital currency tests its various visions ${ }^{17}$, variants, and ways of functioning. The prototype, for example, for Petro, were the rules and blockchain technology known from Bitcoin. At that time, the term Central Bank Cryptocurrencies (CBCC's ${ }^{18}$ was widely used, which was understood as: "an electronic form of central bank money that can be exchanged in a decentralized manner, in a peer-to-peer network, which means that transactions take place directly between users, without the involvement of a trusted third party" ${ }^{\prime 1}$. The reasons for the development and further intensified work should be found in two more contributions. The first, where Sweden may be an example, is related to the decline in the demand for cash over the past decade. The development of the cashless society made Riksbank - the Swedish National Bank, start work-

16 J.M. Villavarde, Bittersweet Story of the Petro, weisscypro.com, https://weisscrypto.com/en/article/bittersweet-story-of-the-petro-venezuela [access: 6.12.2020].

17 According to the report of the Bank for International Settlements from 2020, $70 \%$ of all central banks of individual countries analyze the possibility of issuing their own digital currency. $10 \%$ of respondents indicate that they will implement such a solution within the next 3 years, and $20 \%$ within six years. C. Boar, H. Holden, A. Wadsworth, Impending Arrival - A Sequel to the Survey on Central Bank Digital Currency, "BIS Papers" 2020, no. 107.

18 Originally, the term Digital Fiat Currency (DFC) was used for Central Bank Digital Currencies. Vide Q. Yao, A systematic framework to understand central bank digital currency, „Science China Information Sciences" 2018, vol. 61, no. 3, 033101.

19 L.M. Bech, R. Garratt, Central bank cryptocurrencies, „BIS Quarterly Review" 2017, p. 56. 
ing on the e-crown ${ }^{20}$. However, it was clear from the outset that the goal was not to replace fiat money but to create an alternative to $\mathrm{cash}^{21}$. In 2020, the Swedes started a pilot program, which is expected to last until February 2021 (work on the article was completed in December 2020) ${ }^{22}$. The official document of the Riksbank indicated that by using the infrastructure created in cooperation with a commercial entity, merchants and payers would be able to use electronic money via a dedicated application. The designed system, operating in the P2P architecture, works around the clock and allows for transferring payments between network participants online and offline - without being connected to the network. The e-crown is purchased with traditional funds accumulated on a bank account.

Apart from fighting the effects of the financial crisis and hyperinflation in non-democratic countries and the withdrawal of society from cash, another premise for undertaking work on CBDC is to create an information society ${ }^{23}$. Although this is a secondary premise to the others, it is important due to the currently observed political and social processes. A convenient illustration of the model is Ecuador, in which the national currency has been the US dollar since 2000, and the Central Bank of Ecuador issues the so-

20 Sveriges Riksbank, Project plan for the eKrona, 2017.

21 C. Skingsley, Should the Riksbank issue e-krona?, „FinTech Stockholm" 2016, no. 16.

22 Sveriges Riksbank, The Riksbank's e-krona pilot, 2020.

23 The information society is a society that not only has developed means of information processing and communication, and information processing is the basis for generating the national income and provides livelihoods for the majority of society. Vide T. Goban-Klas, P. Sienkiewicz, Społeczeństwo informacyjne: Szanse, zagrożenia, wyzwania, Kraków 1999, p. 43. 
called centavos that correspond to the value and size of its current prices. In 2014, the Monetary and Financial Code (org. Codigo Monetario y Financiero) was adopted, where it was stated that: "electronic money is a monetary value expressed in the currency of Ecuador (i.e., in dollars). The Central Bank of Ecuador issues it on a 1:1 ratio at face value. It can be stored only on electronic devices and is accepted not only by entrepreneurs but also public entities, i.e., it can be used to pay public dues" 24 .

Compared with other Digital Currencies of the Central Bank, a significant difference is that Ecuador's currency, due to the lack of network coverage, was not based on the Internet but the mobile telephone network. The world's first electronic money from the central bank, because the above solution should be included in such categories, was definitively abolished in 2018, after the National Assembly of Ecuador, on the initiative of President Lenin Moreno, passed the act on the liquidation of the system in December $2017^{25}$. Chances for social development and rapid transformation in CBDC are seen in countries such as Tunisia and Senegal, which are exotic from the perspective of universal digitization. The geographic conditions of Africa favor and sometimes even force the use of new technologies, including the opportunities offered by blockchain technology. In addition to the geographic dispersion that leaves many residents un-

24 W. Srokosz, Publiczny pieniądz elektroniczny i kryptowaluty w Ekwadorze - próba ustalenia prawdy, https://www.witoldsrokosz.pl/ $\mathrm{pl} /$ blog/publiczny-pieniadz-elektroniczny-i-kryptowaluty-w-ekwadorze-proba-ustalenia-prawdy [access: 12.12.2020].

25 L.H. White, The World's First Central Bank Electronic Money Has Come - And Gone: Ecuarod, 2014-2018, Cato at Libery, https://www. cato.org/blog/worlds-first-central-bank-electronic-money-has-comegone-ecuador-2014-2018 [access: 12.12.2020]. 
able to access traditional banking services. Moreover, most countries are dealing with the consequences of colonial collapse.

The Central Bank's Digital Money can also contribute to combating corruption or other abuses by public authorities that are indirectly a consequence of colonization ${ }^{26}$. The Kingdom of Cambodia is among the countries exotic from the perspective of Western culture, where CBDC has been implemented and operates. A country located in Southeast Asia began testing the possibility of designing a digital currency in July 2019. After more than a year, the National Bank of Cambodia, in cooperation with financial institutions, launched Bekong. Residents can use a smartphone application and QR codes to make transactions with Cambodian rieal or US dollar. According to the plans, the further development of the central bank's digital currency is to increase the financial inclusion of residents and contribute to economic growth ${ }^{27}$. Somewhat secondary, because work began much earlier. However, in the case of Cambodia, it is important that Bekong contributes to the fight against the coronavirus.

A high level of advancement of work on CBDC was observed in Uruguay, where, in 2014, the act on financial integrity and improvement of the payment system through

26 L.S. Nanez Alonso, A.M. Echarte Fernandez, D. Sanz Bas, J. Kaczmarek, Reasons Fostering or Discouraging the Implementation of Central Bank-Backed Digital Currency: A Review, „Economies” 2020, vol. 8, no. 2, p. 41 .

27 K. Sekiguchi, T. Onishi, Cambodia debuts digital currency as emerging countries lead charge - Central banks of smaller economies aim to boost their paper currencies, Nikkei Asia, https://asia.nikkei.com/Spotlight/Cryptocurrencies/Cambodia-debuts-digital-currency-as-emerging-countries-lead-charge [access: 12.12.2020]. 
its digitization was adopted ${ }^{28}$. Three years later, a six-month pilot program began ${ }^{29}$, a token technically different from those that had been the subject of studies so far. This time, instead of a blockchain or a Distributed Ledger Technology (DLT), the token was directly on the phone, and the transaction took place directly between users. The E-Peso contained the same information as a physical banknote: serial number, signature, and guarantee of the value of the Central Bank ${ }^{30}$. This solution was therefore contested due to the lack of decentralization and anonymity, but the results of the pilot showed great interest of the public. However, there is no information that the Central Bank of Uruguay is preparing for the massive implementation of e-currency. Against the background of the above examples, Europe's situation in a kind of technology race at the start was not good. In 2019, individual financial institutions on a large scale began to notice the potential of CBDC. In the European Union, works have been intensified by the European Central Bank. In October 2020, the task force report on the possibility of issuing the digital euro was published ${ }^{31}$. The authors indicate a need to intensify work on creating the digital euro, and the dominant premise has again become the digitization of society, the growing importance of elec-

28 M. Alvez, R. Lluberas, J. Ponce, The cost of using cash and checks in Uruguay, „Journal of Central Banking Theory and Practice” 2020, vol. 9, no. 2, pp. 109-129.

29 Banco Central Del Uruguay, EL BCU present un plan piloto para la emission de bilietes digitales, https://www.bcu.gub.uy/Comunicaciones/Paginas/Billete_Digital_Piloto.aspx [access: 14.12.2020].

30 N. Rahul, K. Baird, Uruguay's e-Peso: How a Small Nation Built the World's First $C B D C$, https://beincrypto.com/uruguays-e-peso-how-asmall-nation-built-the-worlds-first-cbdc/ [access: 15.12.2020].

31 European Central Bank - Eurosystem, Raport on a digital euro, 2020 . 
tronic payments, and the desire to create a secure and stable payment system.

In Europe, in addition to work at the European Union level, individual countries, as part of their policy of creating monetary policy, research the possibility of introducing the digital currency of the central bank into circulation. In its report, Deutsche Bank ${ }^{32}$ points out the role and the need to intensify work on CBDC in connection with the COVID-19 pandemic, accelerating the "digital cash revolution". Tests on the digital euro have already taken place in France ${ }^{33}$, and other countries such as Estonia are working with private actors to start research ${ }^{34}$. What distinguishes Europe from the achievements of other countries is that the role of Distributed Ledger Technology is strongly emphasized. The term was popularized in January 2016. Contrary to blockchain technology, the data in a distributed register is stored continuously without dividing it into blocks ${ }^{35}$.

32 Deutsche Bank Research, The Future of Payments Part III. Digital Currencies: the Ultimate Hard Power Tool, Corporate Bank Research 2020.

33 Vide Banque de France - Eurosysteme, Avancement de la demarche d'experimentations de monnaie digitale de banque centrale lancee par la Banque de France - Avancement de la demarche d'experimentations de monnaie digitale de banque centrale lance par la Banque de France, https://www.banque-france.fr/communique-de-presse/avancement-de-la-demarche-dexperimentations-de-monnaie-digitale-de-banque-centrale-lancee-par-la [access: 15.12.2020].

34 M. Misiura, Bank Centralny Estonii rozpoczyna badania nad $C B D C$, https://cryps.pl/bank-centralny-estonii-rozpoczyna-badanianad-cbdc/ [access: 15.12.2020].

35 More about Distributed Ledger Technology, e.g. S. Olnes, J. Ubacht, M. Janssen, Blockchain in government: Benefits and implications of distributed ledger technology for information sharing, "Government Information Quarterly" 2017, vol. 34, no. 3, pp. 355-364. 


\section{China as a World Leader in Works on Digital Fiat Currency - Analysis of Opportunities and Threats of Potential Implementation}

The world leader in the work on the state digital currency is the People's Republic of China, where the product is officially referred to as Digital Currency Electronics Payment (DCEP). Although Cambodia or the Bahamas ${ }^{36}$ have already implemented solutions in digital currency, they are supported by central banks and co-created by other institutions. China began its first research into the implementation of the digital state currency vision in 2014. The work was intensified in 2019 when Facebook announced that it was working on Libra ${ }^{37}$. Then the digital currency became a priority for the government, which resulted in two pilot programs conducted by the People's Bank of China in 2020. The first was carried out in October when the central bank handed out "red envelopes" to 50,000 randomly selected people in the city of Shenzhen. Lottery winners received 200 e-yuan each for the mobile application ${ }^{38}$. December 12 in the so-called "Couples day", a second edition is planned. At that time, the

36 On October 20, 2020, the Central Bank of the Bahamas released the official digital money. Then the sand dollar began to function, which is the digital currency of the Bahamian dollar. According to the plans, the digital version of the Bahamas dollar is to facilitate access to financial services for all citizens, https://www.facebook.com/sanddollarbs/ [access: 16.12.2020].

37 T. Copeland, Key details on China's digital currency have been released, https://decrypt.co/18010/breaking-news-china-reveals-key-details-on-its-digital-currency [access: 16.12.2020].

38 A. John, Explainer: How does China's digital yuan work?, Reuters, https://www.reuters.com/article/us-china-currency-digital-explainer-idUSKBN27411T [access: 16.12.2020]. 
ability to conduct transactions directly between users. Additionally, as part of the program, the residents of Chengdu, Xiongan, and Suzhou could use the digital renminbi ${ }^{39}$. The issued tokens are based on the bank's private blockchain, operate in the peer-to-peer network, and are created in cooperation with two platforms: Alipay and WeChat Pay, which are finally to be integrated with the digital renminbi.

Both the Chinese solutions and all the others discussed in the article carry specific opportunities and threats. In the case of China, which is a case study for the presented study, the analysis should consider additional factors indicated in the introduction. They are associated with an undemocratic political regime, the inherent feature of which is the desire to control every sphere of an individual's life. The dissemination of digital currencies controlled by state institutions will make it possible to track the process of money exchange between citizens. Therefore, in China, digital currency can be a powerful tool to support the still developing Social Credit System. In democratic regimes, on the other hand, where trust in power is high, control over the monetary circulation will help to fight financial crime and exercise supervision over the tax system. Therefore, CBDC, although it provides a powerful tool for controlling citizens and allows for tracking every transaction made, can contribute to the elimination of social pathologies related to money trading.

The category of universal advantages of digital currencies, applicable not only in China but also in any other proj-

39 O. Wang, China's latest digital currency test doubles down on previous trial, nudging merchants and consumers to embrace e-yuan, South China Morning Post, https://www.scmp.com/economy/china-economy/ article/3115100/chinas-latest-digital-currency-test-doubles-down-previous [access: 27.12.2020]. 
ect, includes the security of a cryptographically secured system and technological efficiency. The algorithms used in blockchain are the achievements of many years of efforts by specialists in cryptology. They also make system participants independent because the system operates 24 hours a day, which means that the transfer of funds is performed in real time. Another dimension of security provided by digital currencies is the lack of a physical form of CBDC. Thanks to this, the token cannot be destroyed, unlike fiat money, and it is also difficult to counterfeit or forge it. Compared to cryptocurrencies or other financial instruments, digital currencies are likely to be price stable.

The social benefits of a potential CBDC implementation are related to the financial inclusion of people who hitherto remained outside the banking system. It will be evident in countries where trust in the banking system on the part of citizens is at a relatively low level. Safe, easily accessible, because with their smartphones, bank accounts are a remedy for the mentioned problems. Inclusively financial will apply to both the situation in Senegal already described, but it will be important in China. For geographic reasons, citizens of the Middle Kingdom may often have problems with equal access to bank money. The costs of maintaining bank accounts remain significant or even zero. The popularization of CBDC may eliminate the potential problem of financial residency. Suppose the digital currencies of central banks were to replace modern bank money in the future entirely. In that case, when considering the opportunities and threats, one should indicate, among other things, the potential problem related to digital exclusion. Despite the simplicity of the solutions used, any technological innovation, especially among older people, causes problems. 
When analyzing potential problems related to the development of CBDC, attention should be paid to the geopolitical dimension of the technological effort undertaken by individual actors in the international arena. Striving to create digital currency is not only about the prestige and dominance that has historically been attributed to superpowers. The massive use of blockchain technology and digital fiat currencies may contribute to redefining the current political order. The Chinese do not hide that by starting work on a digital asset, they would like to break the world domination of the dollar as the primary settlement currency ${ }^{40}$. One should also bear in mind the example of South Korea, which in the last decade of the twentieth century opted for new technologies, which made it possible to transform the country and eliminate the neglect of the war period. Countries that manage to gain a research advantage can only gain. An inevitable and even natural consequence of the current processes is the departure from fiat money in favor of electronic payments, including Central Bank Digital Currency. Implementing the central bank's digital currencies may lead to the strengthening of the position of central banks as creators of the state's fiscal policy in the national financial system.

\section{Summary}

Three development trends are observed among virtual electronic payment instruments based on blockchain technology. The first one is related to cryptocurrencies, which are

40 D. Vincent, One day everyone will use China's digital currency, BBC News, https://www.bbc.com/news/business-54261382 [access: 20.12.2020]. 
gaining supporters again after bitcoin halving in May 2020, and it seems that their importance will grow. The second instrument are stablecoins, which, unlike cryptocurrencies, are price-stable due to the mapping in another real asset. The third one is the Digital Currencies of Central Banks, which is still a new and dynamically developing instrument. Due to the number of projects already completed, it is not easy to generalize and indicate the difference between each of the categories. Generally speaking, the level of anonymity provided to users will differ between the three and the legal status at the level of individual countries. Some, such as the Petro, remain at the intersection of two groups of instruments. Although the exchange rate of the Venezuelan currency, at least in the declarative aspect, was to be related to the price of oil, at the same time, the project has features that assign it to digital state currencies.

Two trends can be seen in the debate on the further possible direction of CBDC development. In the quantitative dimension, the dominant belief is that digital currencies are to complement traditional payment methods. It is therefore not assumed that paper money will be withdrawn from circulation in the foreseeable future. The second variant is, as it were, contrasted, where the CBDC is ultimately to be a new payment method that will replace the previously known bank deposits. At such an early stage of development, it is difficult to predict how the digital currencies of central banks will eventually develop. However, there is a noticeable tendency that successive societies more and more often stop using paper money for the benefit of digitized money. Therefore, it should be presumed that banks will issue and deliver traditional money as long as there is a social demand. In the long run, its digital form may opti- 
mize the possibilities of using the banking system and contribute to its diversification.

The dissemination of $\mathrm{CBDC}$ is subject to at least several conditions. Each logically acting authority must take care of the financial stability of the state. Therefore, the introduction of digital currency cannot affect it. So far, it is difficult to imagine the complete elimination of cash from circulation. Hence, the CBDC should rather coexist and be a complement to classic forms of money. In the first phase of its existence, CBDC should finally be promoted as an innovative and effective value exchange system because the banking system may eventually destabilize in the event of sudden, revolutionary changes ${ }^{41}$. The implementation process itself is carried out according to non-uniform technical standards. However, unlike cryptocurrencies, the basis of digital fiat currencies will be Distributed Ledger Technology. Instead of the blockchain known from cryptocurrencies, DLTs are fully replicated, shared, and synchronized registries. Distributed registers are common databases where all users are known and verified, and the data are continuous. Unlike cryptocurrencies, central bank digital currencies will be centralized and devoid of pseudonymity if DLT becomes the dominant technology. The register on which their functioning will be based will be kept by the central bank, government, or a private entity, but in cooperation with the state institution. Automatically posted operation in a distributed ledger using a peer-to-peer network eliminates the need for bank ledgers.

In the long term, the implementation of the central bank's digital currency by China could have numerous geo-

41 Bank for International Settlements, Central bank digital currencies: foundational principles and core features, 2020, p. 1. 
political consequences. The attempt to redefine the world order, which we observe today, is ultimately supposed to make the Middle Kingdom the first world economy. Additionally, the intensive development of the New Silk Road may potentially be supported by e-yuan. When China becomes a monopolist in the field of digital finance, it will be able not so much to impose but expect its partners to adopt new solutions. The digital Yuan, which is currently being tested intensively, if the project is successful, may contribute to the growth of China's importance in the world and be a supporting tool in the attempt to change the world order.

\section{Bibliography}

Alvez M., Lluberas R., Ponce J., The cost of using cash and checks in Uruguay, "Journal of Central Banking Theory and Practice" 2020, vol. 9, no. 2.

Auer R., Cornelli G., Frost J., Covid-19, Cash, and the Future of Payments; Technical Report; Bank for International Settlements, Basel 2020.

Banco Central Del Uruguay, EL BCU present un plan piloto para la emission de bilietes digitales, https://www.bcu. gub.uy/Comunicaciones/Paginas/Billete_Digital_Piloto. aspx.

Bank for International Settlements, Central bank digital currencies: foundational principles and core features, 2020.

Banque de France - Eurosysteme, Avancement de la demarche d'experimentations de monnaie digitale de banque centrale lancee par la Banque de FranceAvancement de la demarche d'experimentations de mon- 
naie digitale de banque centrale lance par la Banque de France, https://www.banque-france.fr/communique-depresse/avancement-de-la-demarche-dexperimentationsde-monnaie-digitale-de-banque-centrale-lancee-par-la; https://cryps.pl/bank-centralny-estonii-rozpoczynabadania-nad-cbdc/.

Barrdear J., Kumhof M., The Macroeconomics of Central Bank Issued Digital Currencies; Technical Report 605, London 2016.

Bashir I., Mastering blockchain, Birmingham 2017.

Bech M.L., Garratt, R., Central bank cryptocurrencies, „BIS Quarterly Review" 2017.

Boar C., Holden H., Wadsworth A., Impending Arrival A Sequel to the Survey on Central Bank Digital Currency, "BIS Papers" 2020, no. 107.

Chappell B., Venezuela Will Create New 'Petro' Cryptocurrency, President Maduro Says, NPR, https://www.npr. org/sections/thetwo-way/2017/12/04/568299704/venezuela-will-create-new-petro-cryptocurrency-presidentmaduro-says.

De Nisco R.A., Innovation, TOP 10 emerging technologies of 2019, https://www.techrepublic.com/article/top10-emerging-technologies-of-2019/.

De Silva J., Parker K., Broun P., Blockchains - „The most importation since the internet itself', Murfett Legal Professionalism. Understanding. Results 2017, https:// www.murfett.com.au/MurfettLegal/media/Documents/ Article/35-Blockchains-The-Most-Important-InventionSince-the-Internet-Itself.pdf.

Deutsche Bank Research, The Future of Payments Part III. Digital Currencies: the Ultimate Hard Power Tool, Corporate Bank Research 2020. 
European Central Bank - Eurosystem, Report on a digital euro, 2020.

Fabris N., Cashless Society-The Future of Money or a Utopia?, "Journal of Central Banking Theory and Practice” 2019, vol. 8, no. 1 .

Goban-Klas T., Sienkiewicz P., Społeczeństwo informacyjne:

Szanse, zagrożenia, wyzwania, Kraków 1999.

John A., Explainer: How does China's digital yuan work?, Reuters, https://www.reuters.com/article/us-china-currency-digital-explainer-idUSKBN27411T.

Kriwoluzky A., Huun Kim Ch., Monetary Dialogue Papers:

Public or Private? The Future of Money, Luxembourg 2019.

Mougayar W., The Business Blockchain: Promise, Practice and Application of the Nest Internet Technology, Hoboken 2016.

Nakamoto S., Bitcoin: A peer-to-peer Electronic Cash System, https://bitcoin.org/bitcoin.pdf.

Nanez Alonso S.L., Echarte Fernandez M.A., Sanz Bas D., Kaczmarek J., Reasons Fostering or Discouraging the Implementation of Central Bank-Backed Digital Currency: A Review, „Economies” 2020, vol. 8, no. 2.

Olnes S., Ubacht J., Janssen M., Blockchain in government: Benefits and implications of distributed ledger technology for information sharing, "Government Information Quarterly" 2017, vol. 34, no. 3.

Piech K., Leksykon pojęć na temat technologii blockchain i kryptowalut, Warsaw 2016.

Sekiguchi K., Onishi T., Cambodia debuts digital currency as emerging countries lead charge - Central banks of smaller economies aim to boost their paper currencies, Nikkei Asia, https://asia.nikkei.com/Spotlight/Cryp- 
tocurrencies/Cambodia-debuts-digital-currency-asemerging-countries-lead-charge.

Skingsley C., Should the Riksbank issue e-krona?, „FinTech Stockholm" 2016, no. 16.

Srokosz W., Publiczny pieniadz elektroniczny i kryptowaluty w Ekwadorze - próba ustalenia prawdy, https://www. witoldsrokosz.pl/pl/blog/publiczny-pieniadz-elektroniczny-i-kryptowaluty-w-ekwadorze-proba-ustaleniaprawdy.

Sveriges Riksbank, Project plan for the eKrona, 2017.

Sveriges Riksbank, The Riksbank's e-krona pilot, 2020.

Swam M., Blockchain: Blueprint for a New Economy, Newton MA 2015.

Szpringer W., Blockchain jako innowacja systemowa: od internetu informacji do internetu wartości: wyzwania dla sektora finansowego, Warsaw 2019.

Tapscott D., Tapscot A., Blockchain Revolution: How the Technology Behind Bitcoin is Changing Money, Business and the World, London 2016.

Villavarde M.J., Bittersweet Story of the Petro, weisscypro. com, https://weisscrypto.com/en/article/bittersweetstory-of-the-petro-venezuela.

Vincent D., One day everyone will use China's digital currency, BBC News, https://www.bbc.com/news/business-54261382.

Wang O., China's latest digital currency test doubles down on previous trial, nudging merchants and consumers to embrace e-yuan, South China Morning Post, https://www. scmp.com/economy/china-economy/article/3115100/chinas-latest-digital-currency-test-doubles-down-previous. White H.L., The World's First Central Bank Electronic Money Has Come - And Gone: Ecuarod, 2014-2018, Cato at 
Libery, https://www.cato.org/blog/worlds-first-centralbank-electronic-money-has-come-gone-ecuador-2014 $-2018$.

Yao Q., A systematic framework to understand central bank digital currency, „Science China Information Sciences” 2018, vol. 61, no. 3, 033101.

\begin{abstract}
The study aims to analyze the Central Bank Digital Currency project on the example of the Digital Yuan. In the first part of the work, using the example of other countries, the main reasons for starting work on a digital fiat currency were indicated. The most important ones are: the digital transformation of societies and the departure from paper money, combating the effects of a financial collapse (hyperinflation), striving to make safe financial transfers, and fighting the coronavirus pandemic as an indirect, secondary one. Taking the case study of China, the second part of the work analyzes the opportunities and threats that may result from implementing the vision of the digital currency of the central bank. The digitization of societies seems to be inevitable. Therefore, it is necessary to consider in which direction the further development of CBDC may go? Two different scenarios seem natural. The first, dominant one, indicates that digital currencies are intended to complement traditional payment methods. The second, on the other hand, assumes that the central bank will withdraw cash, and citizens will only use digital virtual currency.
\end{abstract}

Keywords: Central Bank Digital Currency, Digital Currency Electronics Payment, Distributed Ledger Technology, People's Bank of China, blockchain, cryptocurrencies, Yuan

\begin{abstract}
Abstrakt
Celem badania jest analiza projektu cyfrowej waluty Banku Centralnego na przykładzie cyfrowego juana. W pierwszej części pracy wskazano główne przyczyny rozpoczęcia prac nad walutą fiat (pie-
\end{abstract}


niądzem fiducjarnym) na podstawie obserwacji innych państw. Do najważniejszych należy zaliczyć: transformację cyfrową społeczeństw i odejście od pieniędzy papierowych, walkę ze skutkami załamania finansowego (hiperinflancją), dążenie do zapewnienia bezpieczeństwa transakcji finansowych oraz walkę z pośrednimi skutkami pandemii koronawirusa. Druga część pracy dotyczy Chin, a dokładnie szans i zagrożeń, jakie mogą wynikać z implementacji wizji Banku Centralnego polegającej na stworzeniu cyfrowej waluty. Cyfryzacja społeczeństw wydaje się w tym kontekście nieunikniona. $\mathrm{Z}$ tego powodu konieczne jest zastanowienie się nad kierunkami, w których może podążyć projekt Banku Centralnego. Szczególnie prawdopodobne wydają się dwa scenariusze. Pierwszy wskazuje na to, że waluty cyfrowe powstają po to, by uzupełnić funkcjonowanie pieniądza tradycyjnego. Jednakże drugi zakłada, że Bank Centralny całkowicie wycofa $\mathrm{z}$ obiegu gotówkę, a obywatele będą mogli posługiwać się wyłącznie walutą cyfrową.

Słowa kluczowe: cyfrowa waluta Banku Centralnego, Digital Currency Electronics Payment, technologia rozproszonego rejestru, Bank Ludowy Chin, łańcuch bloków, kryptowaluty, juan 
Krzysztof Marecki

Szkoła Główna Handlowa w Warszawie

ORCID ID: https://orcid.org/0000-0003-3058-1523

\section{Agnieszka Wójcik-Czerniawska}

Szkoła Główna Handlowa w Warszawie

ORCID ID: https://orcid.org/0000-0002-9612-1952

\section{Cryptocurrencies in the Asian Financial Market}

\section{Cryptocurrencies on the Traditional Financial Market}

The financial system is part of the economic system. It makes co-creating purchasing power and providing services that allow it to circulate in the economy possible. It consists of a market-based financial system in which the services are provided through market mechanisms and the public (fiscal) financial system ${ }^{1}$.

Analyzing the country's financial system from the perspective of cryptocurrencies, it is important to consider monetary policy, which is part of economic policy - alongside fiscal and structural policies. The basic premise for the proper monetary policy of the state is to care for the value of the national currency, hence ensuring the right amount of money in the market so the economy could develop without any obstacles and prices were stable ${ }^{2}$. It is worth emphasiz-

1 T. Włudyka, Polityka Gospodarcza, Warsaw 2007.

2 M. Burda, Ch. Wypolsz, Makroekonomia, podręcznik europejski, Warsaw 2000. 
ing that this is the initial assumption of the state's financial (monetary) policy. In the era of internet money, including transactions in the finance area, technology is changing ${ }^{3}$.

Cryptocurrencies respond to the need to have a decentralized representative unit of value, capable of existing outside the traditional financial system, specifically with a similar operation to stock exchanges. The market forces of supply and demand permanently determine the value to be traded.

Among its main benefits are ${ }^{4}$ :

- Trend towards demonetization: Although a little more disruptive, cryptocurrencies, like credit cards, are part of the payment methods for the execution of digital transactions, which seek to replace the use of paper money in traditional markets. The reasons are varied and even paradoxical, considering in some cases, as a tool to combat parallel activities or the "black market".

- Associated profitability: Its high profitability, proportional to its risks, is also considered one of its benefits.

- Assets or investments with high returns tend to attract many, so it is expected that cryptocurrencies will focus on attention, even for supervised entities such as the financial sector. However, the latter will have to do so under rigorous supervision models.

- Their decentralized and unregulated nature: Another of their advantages is associated precisely with why

3 J. Gali, Monetary policy, inflation and the business cycle, New Jersey 2008, pp. 23-45.

4 Criptomonedas, un jugador más del mercado financiero, https:// theonebrief.com/latam/post/criptomonedas-un-jugador-mas-del-mercado-financiero [access 10.12.2020]. 
they arose, that is, the fact that they are outside the control of monetary policies and policy decisions.

Cryptocurrency's greatest advantage is also their greatest risk: they are not regulated, and since it is not, one can make any transaction with it.

In addition to the benefits and expectations that these currencies arouse, the risks associated with their expansion appear.

One of the main challenges, and in turn threats as the differentiating factor of its current nature, is to have a supervisory or surveillance body that gives it a legal framework and integrates its risks and challenges with social policy without neglecting the tax environment in the country.

In the case of the developing countries in Asia and, for example, in South America (Columbia), the Financial Superintendence is looking for the most appropriate way to regulate cryptocurrencies. It cannot do that independently, as it must be a part of an entire monetary policy.

On the other hand, since cryptocurrencies are ultimately a tradable electronic record, they are subject to loss exposed to risks not contemplated in traditional policies.

Nevertheless, we should remember that the risks with cryptocurrencies are not tied exclusively to the risks associated with uncontrolled currency volatility but also to their losses or theft.

Beside the absence of regulation and control by local or global supervisors, it makes a partial or total loss of said assets difficult to be assumed by any risk transfer mechanism such as insurance policies, deposit insurance, and even without the possibility of complaint

Despite the growing boom of cryptocurrencies and their accelerated expansion, even the traditional market has many 
challenges ahead to accept them properly with a minimum risk assumed by their users.

On understanding what this type of currency makes up, the insurance market is just beginning to review the most appropriate options for the risks derived from its administration, leading to the study of structures that complement or exceed traditional bank policies ${ }^{5}$.

Thus, the very nature of this new player implies new rules, leading the different members of the traditional market to reinvent themselves and seek new and better options that facilitate their adequate adaptation.

\section{The Behavior of Cryptocurrencies in the Forex Market}

Approaching cryptocurrencies in the currency market becomes a complex task from a two-fold perspective, which is reflected - in the first instance - in its non-state character because they are virtual currencies that do not belong to a specific state. On the other hand, currently, the same level of technological modernization is not identified. Therefore, it is not yet used, in a generalized way, to carry out transactions with Bitcoin, Litecoin, Ethereum, or other existing cryptocurrencies.

The foreign exchange market allows the transfer of monetary species, reducing its importance to the country that issues it.

This market is configured as one of the most important for the different conceptions of globalization since it constitutes a means of opening the market and allowing trade expansion. The foregoing benefits interconnections, either

5 Ibidem. 
between people-company or company-company relations, or other entities capable of being part of the processes within the international economic system.

In short, the foreign exchange market becomes the appropriate setting for currency exchange, preceded by the subjective theory of value, market law, and speculation when converting values from one monetary species to another.

It becomes possible because the coins belong to the state recognized in the international system. Therefore, it is legally enabled to carry out economic transactions with paper money issued in the national territory - or those issued by another state in cases in which a country has adopted a foreign currency as its own.

For this currency to be accepted by different markets around the world, it must have characteristics such as:

a) Durable - it must be able to exist over time without wear, or as little as possible since it can be used repeatedly.

b) Scarce - can then be understood as the restriction on the amount of money in circulation or the difficulty of being produced, reproduced, or copied.

c) Portable - it must be capable of being moved from one place to another, carried by people, and transferred to another individual.

d) Divisible - it must be easily divisible into smaller denominations without losing its total value.

e) Uniform - all representations and their fractions must be identical in their materiality.

f) Acceptable - it must be widely received and demanded by people to use it for transactions.

g) Storable - which can be kept in minimal spaces and with low storage costs. 
h) Transferable - allows the user to have it just received from another user without the need for permission from any authority.

i) Economic - the factors for its production or reproduction in itself must be economic. Otherwise, it will not last in time because its creation is too expensive"6.

In the case of cryptocurrencies, the situation becomes complex since, as mentioned previously, transactions carried out with the currency of a specific State are supported by them. However, when talking about virtual currencies that do not enjoy the same benefit, those involved show a somewhat negative attitude to cryptocurrencies due to the risks they would entail.

At the same time, virtual currencies present a series of advantages and disadvantages for their use and acceptance in different national and international markets.

Table 1. Advantages and disadvantages of using cryptocurrencies in the international markets

\begin{tabular}{|l|l|}
\hline \multicolumn{1}{|c|}{ Advantages } & \multicolumn{1}{c|}{ Disadvantages } \\
\hline Decentralization & $\begin{array}{l}\text { Requires a certain degree of technical under- } \\
\text { standing }\end{array}$ \\
\hline Privacy & Acceptance in the market \\
\hline Public transparency of private transfers & $\begin{array}{l}\text { Confident both in the technology like in the } \\
\text { bank and means of account }\end{array}$ \\
\hline $\begin{array}{l}\text { It is not possible for third parties without } \\
\text { authorization to access the funds of the user }\end{array}$ & \\
\hline Higher speed of units circulation account & \\
\hline Fees low for the transfers & \\
\hline
\end{tabular}

Source: M.A. Lopez, N.E. Rivera, P.E. Dominguez, K.M. Sandoval, Uso de criptomonedas como alternativa de alivio financiero al endeudamiento externo salvadoreno, Use of cryptocurrency as financial relief alternative

6 G.A. González, Las criptomonedas y el Mercado Digital: Una propuesta de estudio obre la economía electrónica, Instituto Politécnico $\mathrm{Na}$ cional 2016, pp. 4-6. 
to debt external salvadoreno, "Escuela de Realciones Internationales" 2019, no. 1; A.G. González, The cryptocurrency and the market: A proposal study on electronic economy, Mexico 2016.

Once the context of cryptocurrencies is known - meaning its operation is currently restricted to the digital market - it is convenient to analyze virtual currencies in the foreign exchange market, such as Bitcoin, Litecoin, and Ethereum. These enjoy the broadest acceptance in digital networks. At the same time, they note movement volume above the average in international markets. Therefore, they are included in the study.

\section{Cryptocurrency in Asia}

According to a report by Blockchain Valley Ventures, Asian exchanges account for more than $95 \%$ of the volume of crypto futures. Exchanges Huobi, Binance, and OKEx lead the market as the top exchanges in the spot and derivatives markets. Asia has taken the lead in the cryptocurrency ecosystem. While the rest of the world is still living in 2020, they are betting on new financial systems with a clear view of the future.

The new report by the Swiss company Blockchain Valley Ventures (BVV) demonstrates with graphs and numbers the superiority of the continent in this regard: more than $95 \%$ of the volume of cryptocurrency futures are handled on exchanges in Asia.

Its growth has significantly increased due to investment in future cryptocurrency derivatives: from the first to the second quarter of this year, it grew from 60 billion to 2.16 billion US dollars. 
Picture 1. Asia as a Global Hub for Cryptocurrency

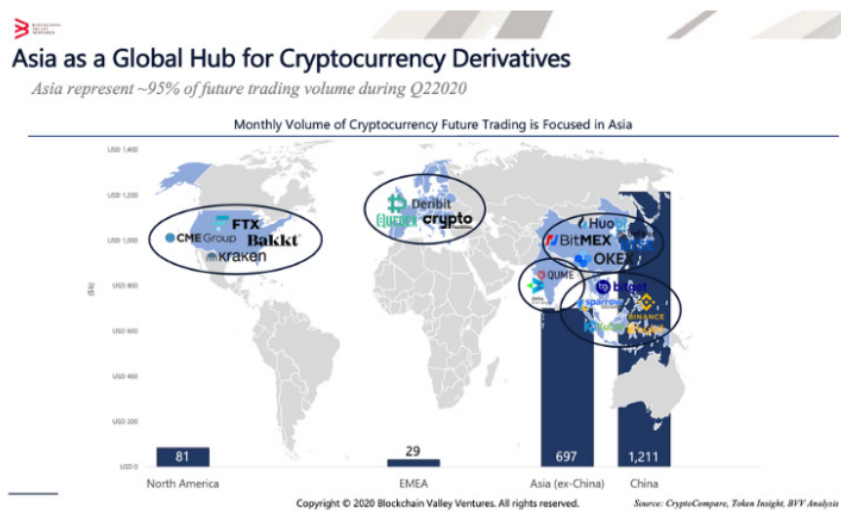

Source: Cryptocompare, Token Insight, BVV Analysis.

Although the spot market of spot volumes has declined, with a decrease of $18 \%$, it continues to be the leading sector, with a figure of $\$ 5.44$ billion. Considering both markets, both the derivative and the spot, Huobi, Binance, and OKEx are the dominant exchanges in the market.

Huobi is a cryptocurrency exchange based in Singapore and founded in China. Binance is headquartered in Malta and is considered the largest platform in the world. OKEx was created by Star Xu and also operates from a small island in the Mediterranean Sea. BitMEX (registered in Seychelles) and Coinbase (works from California in the United States) are other exchanges that lead the field.

\section{Acceptance and Use of Cryptocurrencies in the Different Asian Markets}

Since their appearance, cryptocurrencies have been subject to public scrutiny, and they would not get rid of the doubt 
of the probable users. Questions such as: - will it be safe to use? What if they disappear? Who responds if something goes wrong? - between others that indeed the first group of people or users was made, although It is known that not even with all the possible questions the operation stopped of digital currencies so it cannot be denied that:

[...] the financial system prepares for the inclusion of cryptocurrencies within it as a fundamental part of the global economy and digital finance. Virtual currencies have taken sides as their values have increased exponentially, and as they arise with it forces other currencies that can compete with Bitcoin?

On the other hand, different international institutions have pronounced before the use of digital currencies, some for good, others for discrediting them, and in some cases, the same institution has put into perspective the advantages and disadvantages of this relatively recent form of payment, for example:

The president of the European Central Bank, Mario Draghi, said that, although cryptocurrencies are not mature and stable enough to be able to regulate them in international financial mechanisms and be members of the international monetary system; yes he bet on the impulse, growth, and protection of governments and international agencies in order to stabilize, give confidence and be an element that, in the near future, can develop" ${ }^{8}$. In this sense, it is essential to mention that economic power, such as the United States, which actively participates in the world market, has not been left be-

7 Oro y Finanzas, Las criptomonedas como parte del panorama financiero internacional, https://www.oroyfinanzas.com/2017/10/criptomonedas-parte-panorama-financierointernacional/ [access: 2.09.2020].

8 Ibidem. 
hind in virtual currencies. Unlike "American entrepreneurs, developers and authorities have been figures prominent in the blockchain eco-system", due to the high digital technology with which they count. However, not everything is positive since it also happened that in the United States, the issue reached the Senate and National Security. "Since early 2012, US government institutions have expressed concern about the advanced use of cryptocurrencies without any regulation, coupled with the fact that they represent a change concept of the traditional financial system that dominates the North American market. This atmosphere of suspicion began with an FBI document on Bitcoin on April 24, 2012, alarming the authorities about the scope of the decentralized and pseudoanonymous currencies. Later, it was aggravated by the Silk Road scandal in 2013 that linked Bitcoin to the market black from drug sales on the deep web. The case triggered the alerts of the Senate of the United States, which made constant calls to the security agencies, including the Department of Homeland Security (DSH), to take action on the matter and prevent digital currencies from being facilitating tools of illegality returned. Likewise, Silk Road was the antecedent that gave rise to the stigmatization of Bitcoin, relating to the currency with drug trafficking, terrorist financing, and sex trafficking"10.

Furthermore, as in the previous case, other countries have held debates regarding the anonymity of this form of payment and its propensity to be used in international organized crime. However, these actions are not enough to stop using virtual currencies as a means of international payment and its

9 A. Leal, La travesía legal de Bitcoin en Estados Unidos, https:// www.criptonoticias.com/ regulacion/la-travesia-legal-Bitcoin-estados-unidos/ [access: 20.10.2020].

10 Ibidem. 
activity in the foreign exchange market that generates enormous profits to investors. Another aspect of great relevance is the ground that cryptocurrencies have gained in different countries and creating more virtual currencies, such as the Venezuelan Petro. Among the countries that use virtual currencies the most, there are Japan, Singapore, South Korea, India, Australia, South Africa, Estonia, and others. All this puts into perspective how cryptocurrencies have been evolving in different scenarios internationally. Given this, the IMF expressed itself as follows: "the regulation for the operation of Bitcoin and other cryptocurrencies is inevitable, declared the President of the International Monetary Fund (IMF), Christine Lagarde, at the last World Government Summit in Dubai. "It is clearly a domain where we need international regulation and proper supervision. There is probably a bit dark activity in cryptocurrencies" ${ }^{11}$, which confirms its position in building the need to regulate virtual currencies to avoid becoming the main form of committing financial crimes internationally or with a large-scale that it affects several countries simultaneously. Let us see how does it look the cryptocurrency market on the Asian financial market.

Singapore has a positive attitude towards cryptocurrencies, and in 2020 the regulatory authorities issued appropriate regulations that define the legal framework for companies in this industry. In January, Singapore's central bank issued a Payment Services Act that regulates the circulation of cryptocurrencies and the activities of related companies that must comply with anti-money laundering and anti-terrorist financing laws. Cryptocurrency companies must first register and then apply for

11 I. Lozano, FMI: Regulación del Bitcoin es inevitable, http://larepublica.pe/ economia/1196560-fmi-regulacion-del-Bitcoin-es-inevitable [access: 21.10.2020]. 
a license to operate in Singapore. To make it easier for companies to obtain a license, the Singaporean association of cryptocurrency companies and startups has introduced a "code of conduct" to support companies in their license application.

The Singapore government focused not only on legal issues but also began to support domestic blockchain projects. This summer, Singapore's central bank announced that it is ready to test Project Ubin - a multi-currency payment project based on blockchain technology. It has been designed for commercial use to facilitate international payments. The bank also announced its readiness to cooperate with China in creating CBDC (the digital currency of the central bank).

Currently, Singapore has transparent cryptocurrency regulations. The law does not prohibit their possession, use, or exchange for traditional currencies. One can also legally register a cryptocurrency company in Singapore ${ }^{12}$.

"In Japan, GMO Internet is a Japanese company that in February 2018 [began] to pay with Bitcoin to those interested employees, this as a form of familiarization with this type of currencies, with which they hope that an "evangelization" effect will be created toward other people"13.

It is necessary to bear in mind that Japan has always been a pioneer in using cryptocurrencies in the market, but, bizarrely, it is one of the countries least using them as a popular means of payment. Companies like the one described above will pay their employees a part of their salary in this currency and encourage the use and investment of cryptocurrency.

12 T. Pasich, Od otwartych ramion do petnego zakazu: najnowsze regulacje kryptowalut w Azji, http://www.fxmag.pl [access: 12.10.2020].

13 R. Álvarez, En Japón ya hay una compańía que paga a sus empleados con Bitcoin, https://www.xataka.com/criptomonedas/en-japon-ya-hay-una-compania-que-paga-a-sus-empleadoscon-Bitcoin [access: 30.11.2020]. 
Therefore, the company will deliver a part of the payment to its employees, receive an extra percentage as an investment incentive, and prepare the ground to begin mining transactions with that currency.

South Korea has clear cryptocurrency regulations. However, they are more complicated. Digital assets are treated as legal tender. Local cryptocurrency exchanges are tightly controlled by government agencies, including the Financial Services Commission. In addition, the Minister of Economy and Finance may conduct comprehensive inspections of cryptocurrency exchanges. As of September 2017, ICO and trading with leverage are prohibited. In March 2020, the South Korean government issued a law regulating cryptocurrency exchanges in the country. The act will enter into force in March 2021. Blockchain companies will have a 6-month transition period during which they will have to adapt to the new regulations. The act will affect cryptocurrency exchanges, cryptocurrency funds and wallets, companies carrying out ICOs, and other market participants. They will have to comply with financial reporting requirements, conduct customer identification, use only accounts with actual data, and meet data security requirements. In July 2020, the government proposed a $20 \%$ cryptocurrency trading income tax, but so far, it has not come into force.

The government contributes to the development of blockchain technology in the private sector, as exemplified by the blockchain-based payment program in Seongnam and the ability to store cryptocurrencies in four of the largest domestic banks ${ }^{14}$.

So, the principal operation of a currency is based on speculation. It causes a certain discomfort among some states

14 T. Pasich, op.cit. 
that are used to the traditional monetary system. In this part, South Korea will be analyzed to determine the internal workings of cryptocurrencies.

"As part of its efforts to curb the widespread investor speculation that fuels the digital market, South Korea has announced the implementation of new rules starting next month for exchanges in digital currencies, the government said in a statement Thursday. December 28 , collected by The Wall Street Journal. The country is the third-largest market for Bitcoin after the United States and Japan, so the cryptocurrency has not been long in starting to suffer the havoc as drop more than $\$ 1,000^{\prime \prime 15}$.

The behavior observed in the previous section is typical of a State when it is afraid that something will affect its economy, resorting to regulation. In this case, when the measure was announced, the exchange value of that currency fell approximately $\$ 1,000$ and, in general, the restrictions on the currency in markets.

It is directly affected by currency fluctuation, and there is even speculation that Korea "[...] is preparing new legislation that will prohibit the opening of anonymous cryptocurrency accounts and that will give regulators the ability to close exchanges if they deem it necessary" ${ }^{16}$. It would mean a considerable drop in operations in that country.

In India, the situation of cryptocurrency is very complicated. This colossal economy has also found itself in a difficult situation. In September 2019, its currency, the rupee, became the worst-performing currency in the Asian market,

15 P. Beamonte, Corea del Sur anuncia normas para criptomonedas y Bitcoin cae 1.000 dólares, https://hipertextual.com/2017/12/corea-surnuevas-normas-criptomonedas [access: 2.11.2020].

16 Ibidem. 
losing $12 \%$ of its value to the US dollar since the beginning of the year, but that was not the end of declines. The decline in the value of the rupee translated into an increase in interest in Bitcoin (BTC) among Indian citizens. In the second quarter of 2018, the daily trading volume was around 18 BTC. For comparison, in the third and fourth quarters, when the rupee hit the crisis, daily volumes reached $30 \mathrm{BTC}^{17}$.

The relationship between the Indian government and cryptocurrencies is difficult to understand. In 2018, the Reserve Bank of India banned banks from serving cryptocurrency companies. In July 2019, the government planned to go even further by proposing a bill to punish anyone associated with cryptocurrencies with a hefty fine or a prison sentence of up to 10 years.

In March 2019, the Supreme Court of India unexpectedly upheld the petitions of cryptocurrency companies and found the ban on the central bank unconstitutional. Some cryptocurrency exchanges immediately seized the opportunity by resuming trading. However, the situation remains rather precarious, and it is unknown if the government plans to introduce a legal framework for cryptocurrencies. Following a court decision, Indian officials proposed the possibility of banning cryptocurrency trading through legislative changes ${ }^{18}$.

However, it should be emphasized that as a result of COVID-19, platforms involved in the trading of digital currencies in India are under siege. The popularity of cryptocurrencies has not decreased due to the economic crisis. Market cryp-

17 T. Pasich, Kryptowaluty uregulowane w Wenezueli, http://www. fxmag.pl [access: 1.12.2020].

18 T. Pasich, Od otwartych ramion do petnego zakazu: najnowsze regulacje kryptowalut $w$ Azji, http://www.fxmag.pl [access: 12.10.2020]. 
tocurrency P2P Paxful on Thursday announced its record result. On average, new user registrations per month increased by $28 \%$. From January to May 2020, Paxful saw an $883 \%$ increase in its Bitcoin trading volume over the same period last year, from approximately $\$ 2.2$ million to $\$ 22.1$ million. In May 2020, Bitcoin trading volume on the platform was $\$ 6.2$ million, an increase of $41 \%$, and the number of new user registrations increased by $12 \%$ over the month. Not only this exchange is recording massive increases on its platform. Recently, a similar report was published by the Okex exchange, which shows that the number of newly registered users increased by $4100 \%$. This increase was fueled by the Supreme Court, which lifted a banking ban by the central bank, the Reserve Bank of India (RBI), in March.

Wazirx and Unocoin reported that their trading volumes increased ten-fold. Zebpay also saw a significant increase in trading volume and new users during the lockdown. New crypto exchanges are constantly launching in India, while global exchanges are also expanding in this country. Investors are also more willing to invest their capital in Indian crypto startups. "The Indian market has great potential and importance for the future of the crypto economy. People in India are betting on big Bitcoins, which gives them a chance to earn more money. We are actively focusing our efforts on providing cryptocurrency to the masses across the country to help eradicate poverty, boost economies and create jobs, especially in the post-COVID-19 economy", said Ray Youssef, Paxful Co-Founder.

When we look at cryptocurrency in Asia, we cannot forget about the Chinese and Russian markets.

Many cryptocurrency projects started in China. Many well-known cryptocurrency exchanges were based here. 
Despite such promising beginnings, cryptocurrencies have been banned here. In 2017, the People's Bank of China banned ICOs and cryptocurrency exchanges. The Shanghai branch of the Central Bank of China has announced its intention to root the cryptocurrency industry out of the country, treating the sale of tokens as illegal issuance of securities or some other form of illegal fundraising. Soon, the largest cryptocurrency exchanges in the country - Huobi and OK Coin - announced that they had ceased their activities. The turning point came in July 2019, when a Chinese court described Bitcoin as "digital property". This decision marked a change in the approach to cryptocurrency. In October 2019, the President of China, Xi Jinping, called for more efforts to develop blockchain technology. Moreover, the People's Bank of China has made the launch of the Central Bank's Digital Currency (CBDC) a priority. However, the Chinese government is still cautious about both its cryptocurrency approach and digital assets in general and has yet to issue any regulatory provisions in this regard.

However, it is believed that recent events in the world, such as the coronavirus pandemic and the associated economic downturn, could induce the Chinese government to adopt cryptocurrencies legally: "To maintain its status as a leader in technological and financial markets, China, which was overly restrictive, they are currently accelerating efforts to create a regulatory framework for cryptocurrency circulation and are even considering the possibility of their own cryptocurrency".

So far, the Chinese government has yet to introduce the national digital currency, possibly because it would like to replace electronic money with it and create a universal payment system like Alipay that would be used worldwide. 
Currently, the People's Bank of China is carrying out pilot projects in digital currencies in various country regions and has registered at least some patents related to them.

In early August 2020, it was also known that several commercial banks in China were testing digital yuan wallets. At the end of the month, the Communist Party of China reannounced that it was betting on blockchain technology as a key innovation tool for domestic social services.

In July 2019, a state-owned project known as Blockchain Service Network (BSN) was launched to support mid-sized companies in developing blockchain projects by creating public blockchains that comply with Chinese law and operate internationally. It was also announced that BSN will also integrate support for stablecoins, but not earlier than 2021, and will also be able to become an infrastructure for the digital yuan.

Despite all these signs of 'acceptance' of blockchain technology, many Chinese companies do not believe that the government will decide to legalize cryptocurrencies.

However, it is recognized that in the case of China, it is inevitable for the foreseeable future that cryptocurrencies will not be legalized in that country. Currently, cryptocurrencies are seen as a form of investment, not as currencies. When real currencies change hands, they are used most of the time to purchase goods or services. When most cryptocurrencies change hands, $99 \%$ of the volume is currently used for investment purposes. Therefore, of course, they will not replace fiat currencies because they do not function as currencies ${ }^{19}$.

19 Ibidem. 
In Russia, President Vladimir Putin signed a law that will allow transactions with digital financial assets (DFA) from 2021 but will ban cryptocurrencies as a means of payment in Russia.

Digital rights are understood as digital rights, the issue, accounting, and circulation, which is possible only by making entries in the information system based on a distributed register.

They can be an object of pledge, purchase, and sale transactions, exchange of one type of digital asset for another (including those issued according to the rules of foreign information systems), or for digital rights of other types. At the same time, DFA (digital financial assets) are not recognized as a means of payment.

Russian banks and exchanges will become operators of the exchange of digital financial assets with the right to conduct sale and purchase transactions and exchange such assets. For this, they must be included in a special register of the Central Bank.

The Bank of Russia will have the right to determine the signs of DFA, which only qualified investors can acquire, as well as, within a certain amount, unqualified individual investors.

Digital currency in the law means a set of electronic data (digital code or designation) contained in the information system, which are offered and (or) can be accepted as a means of payment, but are not a monetary unit of Russia, a foreign state or an international monetary unit. The civil circulation of the cryptocurrency will be limited.

The legislator defines cryptocurrency as a means of payment and savings, as an investment. However, this means of payment is prohibited from paying for goods and services in 
Russia (the State Duma Committee on the Financial Market).

Russian individuals and legal entities will be able to challenge transactions with digital currency in court only if they have declared these transactions and the possession of cryptocurrency in Russia. Also, the law prohibits officials and other persons who are now not entitled to have accounts (deposits) abroad to have digital currency and digital currency issued in foreign information systems.

At the same time, within the framework of the second reading, some concepts were excluded from the law, including "token" and "mining" - more detailed regulation of digital currencies is planned to be determined in another law, which may be adopted in the autumn session $2021^{20}$.

\section{Cryptocurrency Future Growth}

Summarizing, it can be said that money is one of the most valuable and the most sought-after goods in the world, affecting people in almost every aspect of their lives. One of the most controversial innovations in this field are cryptocurrencies. It is a currency that is not protected by the government regulation or law, making it immune to government interference. The currency is in full swing decentralized and, unlike fiat money, no government may affect its value. The first and the most commonly used cryptocurrency is Bitcoin.

A ledger called a blockchain records all transactions publicly with Bitcoin maintenance, and users are complete-

20 В. Астапкович, Путин подписал закон о регулировании криптовалют с 2021 года, http://www.ria.ru [access: 12.12.2020]. 
ly anonymous. Supply Bitcoins come from "mining", i.e., a process involving complex computation algorithms with increased difficulty over time, making it more costly and resource-intensive, thus less profitable in time.

The demand for Bitcoins is mainly due to their decentralization and anonymity, transaction costs, use for illegal transactions, and as a financial instrument to profit from its price, volatility, or diversification wallet. Other possible uses of Bitcoin include the means of which should be avoided, currency controls, or other sources of government interference and evasion from taxation. However, cryptocurrencies also have disadvantages. Therefore, the currency is decentralized, so there is very little consumer protection; stolen Bitcoins are lost forever and highly vulnerable to code-based attacks. The price is very high, volatile, and therefore very risky. There is a hold on many Bitcoins as well as a lack of liquidity.

This currency is governed in many countries such as the USA, Japan, Finland, and Germany. Countries with strict capital controls, such as China and Iceland, also have a recognized currency and they have forbidden transactions, eliminating the possibility of bypassing restrictions on capital controls.

The study finds that the future derivatives market will grow much faster than cash. It even explains that it has the potential to be ten times more important in the short term. From the wide variety of derivatives between exchanges, BVV predicts that there will be new players in the crypto exchange market in the months to come.

Derivatives are the gateway for institutional investors. The player who can enter the US or European market in a regulated manner will get much institutional capital. 
The analysis also observes the importance of DeFi (decentralized finance), elevating derivatives and achieving greater sophistication of products in the market. The growth of decentralized derivatives is considerable and constant in recent times.

Research carried out by Blockchain Valley Ventures asks: What is next? The company finds that exchanges need additional services and has established some connections.

BVV predicts the pacts between Coinbase-BitFlyer, Bitstamp-Biki.com, Huobi-LedgerX, Binance-ErisX, and Coinbase-ErisX. These unions would allow, in each case, a product expansion, a broader geographic scope, and volume consolidation.

They have analyzed these companies according to more than 30 different parameters, including volumes, product offer, breadth, legal status and license, technical specifications, among others, to find the attractions and potential target of each company.

The importance of Asia in the cryptocurrency and crypto-assets sector is summarized because Asians have a more global and forward-looking perspective. Their thinking is not temporary, but they project what will be long-term. Moreover, they see the potential of digital assets.

In its current version, Bitcoin is unlikely to become an official currency for the general public because it has too many flaws and risks. At the same time, its strengths are not necessarily something the general public wants in a fixed currency. For it to be an innovative currency, it needs to improve what its debit and credit cards have to offer in order to be successful, so cryptocurrencies must be more convenient, safer, and accepted by sellers around the world, in addition to a significant increase in tax revenues - especially 
in case of introducing appropriate regulations stimulating market development - we can expect other, less measurable benefits, including ${ }^{21}$ :

1. Increased interest in "mining" globally present cryptocurrencies generates tens of millions of zlotys of daily income. This will translate into electricity demand, and thus - hard coal will power a power plant.

2. Increased interest in blockchain technology and its application. It means that the country's cybersecurity will increase, transaction costs in the economy will decrease, costs of the financial system operation will decrease, innovation of the country, its competitive position in the world will improve.

3. Increase in the level of education of blockchain specialists - they come mainly from the cryptocurrency sector. (With few exceptions, it is challenging to develop blockchain applications without first cryptocurrency development).

4. There will be an inflow of foreign portfolio investments (provided that there is adequate regulation) on a scale of up to several hundred million dollars a year. Possible, that there will be enterprises with high market value (several projects blockchain in the world is valued over $\$ 1$ billion).

Summarizing the issue of cryptocurrencies and their impact on the financial system on a whole world, not only in Asia, it can also be stated that, among others:

1. Cryptocurrencies are perceived as elements of the country's monetary policy from the perspective of four variables: issuer (central bank or other), form (electronic or

21 A. Wójcik-Czerniawska, Kierunki rozwoju kryptowalut a system finansowy, Warsaw 2020, pp. 341-350. 
physical), accessibility (universal or restricted), mechanism transfer (centralized or decentralized).

2. Blockchain is a new technology that banks can use or a mechanism competing with banks to enable relocation banking transactions with centralized, hierarchical organizations back to decentralized markets.

3. Cryptocurrency is traded on exchanges, and companies have made investments in projects related to virtual currency. These activities depict a technically well-functioning virtual currency system, but still, there is no single international law on the use of cryptocurrencies.

4. Decentralization increases the risk of bankruptcy, as does its volatility prices. Bitcoin can be used to bypass capital controls, but only to a limited extent. Bitcoins in the investment portfolio increase returns and reduce the risk but are also risky, i.e., acting as a primary asset - useful for portfolio diversification. Bitcoin has the liquidity that other fiat currencies have. It is vulnerable to attacks based on code and theft.

"Cryptocurrencies have different risk characteristics than other intangible assets. The blockchain is a record of transactions. In order to use cryptocurrencies, the holder needs to have a key. If that key is lost, the cryptocurrency associated with it is lost forever. It will be necessary for entities to think about the adequacy of their backup and recovery process to prevent the loss of a key and the loss of related assets.

Access to the key gives the holder access to the associated cryptocurrency. Special procedures must be in place, such as encrypting the key or dividing it into components (chunks) and having protocols that ensure that only authorized persons can reassemble the key. 
One cannot ask the cryptocurrency blockchain community to verify an entity's holding of the cryptocurrency. Even this is a notion that is not valid. Therefore, the nature of these assets offers new challenges around financial controls and auditability. For example, management will need to recreate the balances for each key from the entire blockchain public ledger to provide the assurance needed to have correctly established cryptocurrency holdings. These are new challenges" ${ }^{\prime 2}$.

However, since cryptocurrencies are still in the preliminary stage, their actual impact on the traditional financial system will be noticed only in a few years. It will happen when many countries take a firm stance on this phenomenon as a new virtual world of finance created and unexpectedly moved to the traditional world of flat finance.

\section{Bibliography}

Астапкович В., Путин подписал закон о регулировании криптовалют с 2021 года, http://www.ria.ru.

Álvarez R., En Japón ya hay una compańía que paga a sus empleados con Bitcoin, https://www.xataka.com/criptomonedas/en-japon-ya-hay-una-compania-que-paga-asus-empleadoscon-Bitcoin.

Beamonte P., Corea del Sur anuncia normas para criptomonedas y Bitcoin cae 1.000 dólares, https://hipertextual. com/2017/12/corea-sur-nuevas-normas-criptomonedas. Burda M., Wypolsz Ch., Makroekonomia, podręcznik europejski, Warsaw 2000.

22 Deloitte, Thinking Allowed, Criptomoneda: implicaciones para la presentación de reportes financieros, http://www.ifrs.com [access: 30.12.2020], p. 18. 
Cryptocompare, Token Insight, BVV Analysis, http://www. coindesk.com.

Deloitte, Thinking Allowed, Criptomoneda: implicaciones para la presentación de reportes financieros, http://www. ifrs.com.

Gali J., Monetary policy, inflation and the business cycle, New Jersey 2008.

González G.A., Las criptomonedas y el Mercado Digital: Una propuesta de estudio obre la economía electrónica, Instituto Politécnico Nacional 2016.

Leal A., La travesía legal de Bitcoin en Estados Unidos,( The legal journey of Bitcoin in the United States), https:// www.criptonoticias.com/regulacion/la-travesia-legalBitcoin-estados-unidos/.

Lopez M.A, Rivera N.E, Dominguez P.E, Sandoval K.M., Uso de criptomonedas como alternativa de alivio financiero al endeudamiento externo salvadoreno, Use of cryptocurrency as financial relief alternative to debt external salvadoreno, Escuela de Realciones Internationales, no. 1, San Salvador 2019.

Lozano I., FMI: Regulación del Bitcoin es inevitable, http:// larepublica.pe/economia/1196560-fmi-regulacion-delBitcoin-es-inevitable.

Oro y Finanzas, Las criptomonedas como parte del panorama financiero internacional, https://www.oroyfinanzas. com/2017/10/criptomonedas-parte-panorama-financiero internacional/.

Pasich T., Kryptowaluty uregulowane w Wenezueli, http:// www.fxmag.pl.

Pasich T., Od otwartych ramion do petnego zakazu: najnowsze regulacje kryptowalut w Azji, http://www.fxmag. pl. 
The one brief, Criptomonedas, un jugador más del mercado financiero, https://theonebrief.com/latam/post/criptomonedas-un-jugador-mas-del-mercado-financiero.

Włudyka T., Polityka Gospodarcza, Warsaw 2007.

Wójcik-Czerniawska A., Kierunki rozwoju kryptowalut a system finansowy, Warsaw 2020.

\section{Abstract}

Bitcoin was created in 2008 to facilitate peer-to-peer exchanges using blockchain technology. Its use of cryptography to control how it is created and managed led to it being called a cryptocurrency. Bitcoin was the first use-case of the blockchain and has led to further developments in cryptography.

The first value attributed to Bitcoin was in October 2019 when a Bitcoin price of US dollars was 0.00076. In November 2017, Bitcoin was priced at more than $\$ 19,000$. Currently, it is below $\$ 6,000$. The number of corporations willing to accept Bitcoin in exchange for their products has also grown.

Bitcoin is not the only cryptocurrency. The increased use of, and exposure to, cryptocurrencies raises concerns about the financial reporting implications of those who receive, hold, issue, or trade with them.

The existence of more than 1000 types of cryptocurrencies in the world, and the certainty that they will continue to grow, both in number and popularity, is a sign of their boom and their active entry into the international financial market.

Over time, these "virtual currencies" have acquired a greater binding force to the extent that they have become an active part of portfolios supported by entities that give credibility to the credit content of the currency. The situation has begun to occur with Black Rock or Goldman Sachs cases that have sought to add solutions based on Bitcoins to their current portfolio. This type of highly specialized peripheral financial entities has already begun to build funds in which the assets they invest are or include cryptocurrencies. It will not take long to begin to permeate other traditional entities, such as banks and pension funds. 
In this document, we identify some of the questions currently facing different parties dealing with cryptocurrencies, including holders, issuers, and miners, and how does it work on the Asian financial market

The characteristics of cryptocurrencies vary and are crucial for understanding each cryptocurrency attribute. During various economic turmoil, the national currencies of the countries affected wreaked. Then citizens look for help in other assets. Recently, cryptocurrencies and especially Bitcoin, have been very popular in countries affected by the crisis. Today, countries such as India, China, Singapore, Vietnam, Thailand, and South Korea have become centers of blockchain innovation. At the same time, there are also many countries where the legal status of cryptocurrencies is uncertain. Despite this, Asian countries' citizens see an opportunity in decentralized finance such as cryptocurrencies, independent of the centralized national economy.

There are still some questions about expanding the use of currencies, especially regarding how prepared the traditional market is to accept them.

Keywords: cryptocurrency, financial market, Asia, Bitcoin, crisis, opportunity

\begin{abstract}
Abstrakt
Bitcoin powstał w 2008 r., aby wesprzeć wymianę P2P z wykorzystaniem technologii łańcuchów bloków. Wkrótce został nazwany kryptowalutą ze względu na to, że do jego powtania i obiegu używa się kryptografii. Bitcoin był pierwszym przypadkiem powszechnego użycia łańcuchów bloków i przyczynił się do dalszego rozwoju kryptografii.

Początkowa wartość przypisywana Bitconowi wynosiła 0.00076 dolara amerykańskiego. W listopadzie 2017 r., cena Bitcoina wynosiła ponad 19 tys. dolarów. Obecnie plasuje się na poziomie nieco poniżej 6 tys. dolarów. Ponadto wzrosła liczba korporacji gotowych zaakceptować Bitcoin jako zapłatę za swoje towary lub usługi.

Bitcoin nie jest jedyną kryptowalutą. Jednak wzrost liczby kryptowalut zwiększa obawy o bezpieczeństwo transkacji cyfrowych, zwłaszcza wśród grup osób zajmujących się obrotem finansowym tego rodzaju pieniądza.
\end{abstract}


Obecnie można wskazać na występowanie ponad tysiąca różnych kryptowalut na całym świecie i wszystko wskazuje na to, że liczba ta będzie rosnąć. Wzrastać będzie nie tylko zbiór kryptowalut, lecz także ich popularność, co jest jasnym dowodem ich aktywnego wejścia na międzynarodowy rynek finansowy.

Z czasem "wirtualne waluty" nabrały większego znaczenia - do tego stopnia, że stały się nieodłączną częścią portfeli wielu osób, a przez to stałym elementem instytucji finansowych. Pierwszymi były Black Rock oraz Goldman Sachs, które wprowadziły usługi oparte na Bitcoinie do swoich ofert. Ten rodzaj wysoce specjalistycznej działalności jednostek finansowych rozpoczął process budowania funduszy $\mathrm{z}$ inwestycji z uwględnieniem status kryptowalut. Nie minie wiele czasu nim zaczną one wpływać na losy tradycyjnych instytucji finansowych, np. banków, funduszy emerytalnych itp.

W tej pracy identyfikujemy niektóre pytania, na które muszą sobie odpowiedzieć wszystkie jednostki mające do czynienia z kryptowalutami (udziałowcy, inwestorzy, twórcy, wydobywcy). Jedno z nich dotyczy tego, jak będą one funkcjonować na azjatyckich rynkach finansowych.

Charakterystyki kryptowalut są różne, ale kluczowe dla zrozumienia ich poszczególnych typów. Podczas różnych zawirowań politycznych waluty narodowe państw, w których borykano się z takimi problemami, ulegały osłabieniu. Obywatele tych państw szukali wówczas pomocy lub stabilności w innych walutach lub środkach finansowych. Obecnie w takich państwach coraz większym powodzeniem cieszą się kryptowaluty, zwłaszcza Bitcoin. Państwa, takie jak Chiny, Indie, Singapur, Wietnam, Tajlandia czy Korea Południowa, stały się centrami innowacji technologii łańcuchowych. Jedncoześnie jest wiele państw, w których status prawny kryptowalut wciąż nie został rozpoznany. Mimo to obywatele państw azjatyckich widzą dla siebie szanse w kryptowalutach jako zdecentralizowanych środkach płatniczych, niezależnych od scentralizowanych gospodarek narodowych.

Liczba znaków zapytania dotyczących ekspansji kryptowalut nie maleje, zaś kluczowe zdaje się pytanie o to, czy tradycyjne rynki finansowe są przygotowane na ich nadejście.

Słowa kluczowe: kryptowaluta, rynek finansowy, Azja, Bitcoin, kryzys, szansa 


\section{Toghrul Allahmanli}

Lodz University, Odlar Yurdu University

ORCID ID: https://orcid.org/0000-0001-8075-5048

\section{Main Characteristic of Main Export Industries of Azerbaijan}

The favorable geopolitical position of the country's economic potential plays a vital role in strengthening Azerbaijan's independence and protecting the interests of statehood. These factors create the prerequisites for the effective and purposeful foreign policy course that meets Azerbaijan's national statehood interests. However, realizing the existing potential and maximizing them required a rigorous study of international processes and a systematic process that took into account all the details of Azerbaijan's interests. In the modern world, the Azerbaijan Republic, which has chosen the path of democratic society-building and market economy, strives to take advantage of the universal values successfully tested globally to promote the advanced technologies and possibilities of the developed countries in order to realize their potential. Each independent state is an origin of domestic and foreign policy in various directions, characterized by its principles and characteristics. Fulfillment of the foreign policy objectives will facilitate mutually beneficial cooperation with individual states, the integration of international efforts in all areas of economic, political, social, and cultural life, and the consolidation of efforts by states to address all of their emerging problems. At the same time, the 
political line arising from the processes and tasks within the country determines the state's position and foreign policy, direction, and character in the sphere of international relations. The main tasks of the Republic of Azerbaijan in foreign policy are:

- To maintain the independence, sovereignty, and territorial integrity of the country within the internationally recognized borders, to closely link its security with regional and international security systems;

- Achieving a worthy place on the political map of the world based on Azerbaijan's representation in all international and regional organizations, participation in world politics regulated by the rules of civil coexistence, and active participation in the solution of international and regional relations;

- To create equal, mutually beneficial, and mutually beneficial cooperation with all countries of the world, to use these relations as effective factors in the development of economy, science, and culture of the republic;

- To establish partnership and alliance relations with states that are in line with the state and national interests of Azerbaijan, to use their opportunities to strengthen the international position of the republic;

- To work towards the creation of favorable international conditions for the promotion of countries through democracy and a free market economy, pursuing independent domestic and foreign policies;

- Creation of conditions for the implementation of international norms aimed at protection of fundamental rights and freedoms of the population;

- Endeavor to eliminate tensions in the region and establish good neighborly relations; 
- Achievement of the establishment of international support mechanism to prevent or minimize external pressure on Azerbaijan.

All these tasks and specific efforts to implement them are reflected in the practical steps taken by the Republic of Azerbaijan in the area of international, regional, and interstate relations and the agreements signed.

The current foreign policy of Azerbaijan corresponds to the principles of openness and democracy. It should be noted that the principle of ethnic and religious pessimism plays a significant role in determining the relations and relationships of individual states, and it is impossible to ignore the centuries-old historical factor in international politics completely. It always has a significant impact on the establishment and development of interstate relations.

The basic principles underlying the state of Azerbaijan in international, regional, and interstate relations are as follows:

- Not to infringe states' sovereign rights, the internal affairs of each other, to respect countries' development paths, regardless of the difference between the models of state-building and socio-political development, to fulfill their international norms and commitments on time;

- Not to violate the territorial integrity of states following the norms and principles of international law, forcibly change the boundaries and endanger the independence of the state;

- To seek and implement promising steps for equal, mutually beneficial cooperation, protection of common interests and interests in economic, socio-political, and cultural relations, promotion of mutual security, peaceful and beneficial cooperation; 
- Respect for the right of peoples and nations to determine their rights, protect human rights and rights, and so on.

The long-term foreign policy strategy requires the preparation of the current foreign policy program of the states and the priorities for the work to be done under the specific time, place, and conditions.

It should be recognized that during the first years of independence, Azerbaijan's foreign policy priorities were based on several key policies:

1. Carry out a well-thought-out policy within the country and mobilize all citizens, national, social, political, social, and other resources to protect Azerbaijan's sovereignty and territorial integrity.

2. Ensure national security by eliminating threats to the independent statehood of Azerbaijan, using all foreign policy resources, diplomatic and political opportunities.

3. Comprehensive work with major states, international and regional organizations, institutions that can represent Azerbaijan's global interests abroad, with the media, diaspora centers, and other institutions that impact world politics.

4. Assessment and regulation of the existing economic, political, social, and cultural relations of the country within the interests of the independent state.

The role and place of each state in the system of international relations, along with other factors, means that its foreign policy resources understand the whole material and spiritual life of the state. Thus, as an independent state, Azerbaijan is represented internationally with its foreign policy mechanisms and resources, maintains bilateral and 
multilateral relations with foreign countries, international and regional institutions, and ensures its national interests.

The tasks of independent state-building in Azerbaijan are: strengthening independence, nsuring security, territorial integrity, economic interests, etc. It required the implementation of various foreign policies, which differed in their specifics with tasks and tactics. In this regard, the main directions of foreign policy are:

- The establishment of bilateral relations, primarily based on the principles of cooperation with Russia, which have significant influence in the region;

- To get membership status to the CIS in 1993 (http:// cis.minsk.by);

- There is a conflict between Armenian-Azerbaijani. They got ceasefire in 1994;

- Signing of the Azerbaijani-Georgian Declaration. This declaration's name is "Peace, Stability, and Security in the Caucasus". It happened during the official visit of the President of the Republic of Azerbaijan to Georgia on March 8, 1996;

- The fact that the Republic of Azerbaijan has close relations with the most influential and leading countries of the Middle East in all its development;

Azerbaijan has established local and close relations with several foreign countries. These organizations are the European Union, the Council of Europe, the Commonwealth of Independent States, the OSCE, the UN, the Middle East, and the Black Sea Economic Organization.

Successful implementation of various aspects of Azerbaijan's foreign policy, both economically and socially, and politically. 


\section{Conclusion}

Studying the development of economic relations between the Republics of Azerbaijan and Poland has led to several conclusions. These conclusions give an idea of the historical traditions of economic, cultural, and political relations between Azerbaijan and Poland. As it is known, both Azerbaijan and Poland have specific ties with each other regarding their rich history and the ethnos' unique cultural environment. The history of these connections is characterized mainly by those from the 16th century to the present day. Since the beginning of the 19th century, it has always been in the direction of reproduction and at the same time covered various spheres of economic, cultural, and political life.

Today, the relationship is characterized by various analyzes. For example, the chief architect of Baku was Josef Goslawski (late 19th and early 20th centuries), the buildings built by Plosko and Skurevich in defining the architectural image, the active participation of Poles in the formation of the Azerbaijan Democratic Republic, and leading positions in government (Krichevsky brothers, General Maciej Szczecin), etc.), and the fact that in the Second World War, the Azerbaijani Veli bey Yadigarov became a colonel of the Polish national army, etc. The study of economic relations between the Republics of Azerbaijan and Poland at the level of international economic relations identifies sound prospects. The processes taking place in world politics after the collapse of the Soviet empire laid the foundation for the restoration of Azerbaijan's state independence. Poland, as a state, moved away from the idea of a socialist state which entered 
the space of socialism and determined the path of independent action. He began political, economic, and cultural reforms in Europe. It is currently one of the most developed countries in Central Europe due to its economic potential. It is the largest member of the European Union among the members of the Eastern Bloc. As a geoeconomics space of the South Caucasus, Azerbaijan has an exceptional opportunity to meet its growing energy needs. Rich hydrocarbon fields, East-West, South-North transit function, form a solid picture for economic and trade relations prospects. The "one way, one belt" project, formed in the imagination of the transnational world, demonstrates the necessary position and allows for results. In this way, both Azerbaijan and Poland play a more important role in the geo-economic space in which they are represented as regional states. In addition, one of the authors of the initiative implemented by the European Union within the Eastern Partnership program is the Republic of Poland. Azerbaijan's important place in this programme creates conditions for the expansion of Eastern policy and economic ties.

\section{Bibliography}

Europa Publications Limited, Eastern Europe and the Commonwealth of Independent States, Routledge 1998.

Shim J.K., Siegel J.G., Dictionary of Economics, USA 1995. Buckley P., In Memory of Raymond Vernon, "Journal of International Business Studies” 1999, vol. 30, no. 3.

Kukło C., Łukasiewicz J., Leszczyńska C., History of Poland in Numbers, vol. 3, Warsaw 2014.

Kunert A.K., Stownik biograficzny konspiracji warszawskiej 1939-1945, vol. 1, Warsaw 1987. 
LaPorte J., Semi-presidentialism in Azerbaijan, [in:] SemiPresidentialism in the Caucasus and Central Asia, eds. R. Elgie, S. Moestrup, London 2016. Shener S., Saridogan E., The Effects Of Science-TechnologyInnovation On Competitiveness And Economic Growth, Turkey, The $7^{\text {th }}$ International Strategic Management Conference 2011.

\title{
Internet sources
}

Azerbaijan-Poland relations on Aliyev Heritage Archived July 14, 2010, https://web.archive.org/web/201007 14024032/http://library.aliyevheritage.org/en/7202360. html.

https://oec.world/en/profile/country/aze/.

https://www.cia.gov/library/publications/the-world-factbook/geos/aj.html.

https://baku.msz.gov.pl/en/.

\begin{abstract}
The favorable geopolitical position of the country's economic potential plays a vital role in strengthening Azerbaijan's independence and protecting the interests of statehood. These factors create the prerequisites for an effective and purposeful foreign policy course that meets Azerbaijan's national statehood interests. However, realizing the existing potential and maximizing them required a rigorous study of international processes and a systematic process that took into account all the details of Azerbaijan's interests. In the modern world, the Azerbaijan Republic, which has chosen the path of democratic society-building and market economy, strives to take advantage of the universal values successfully tested globally to promote the advanced technologies and possibilities of the developed countries to realize their potential. Each independent state is an origin of
\end{abstract}


domestic and foreign policy in various directions, characterized by its principles and characteristics. Fulfillment of the foreign policy objectives will facilitate mutually beneficial cooperation with individual states, the integration of international efforts in all areas of economic, political, social, and cultural life, and the consolidation of efforts by states to address all of their emerging problems.

Keywords: Azerbaijan on international economy, exports industries, evolution of Azerbaijan foreign trade, Azerbaijan and Poland economic relations, Azerbaijan-Poland cooperation

\section{Abstrakt}

Sprzyjająca pozycja geopolityczna dla potencjału ekonomicznego Azerbejdżanu państwa odgrywa znacząca role we wzmacnianiu niezależności tego państwa i ochrony jego interesów oraz państwowości. Czynniki te stwarzają warunki wyjściowe dla efektywnej celowej polityki wewnętrznej i zagranicznej umożliwiającej realizację interesów narodowych Azerbejdżanu. Jednakże wykorzystanie i maksymalizacja tego potencjału muszą opierać się na analizach procesów międzynarodowych uwzględniająych to, jakie miejsce zajmują wśród nich interesy Azerbejdżanu. W dzisiejszym świecie Republika Azerbejdżanu, która obrała ścieżkę budowania społeczeństwa demokratycznego i gospodarki rynkowej, stara się wykorzystać do realizacji swoich celów powszechne wartości, które zdały egzamin w innych państwach, a także do promowania odkrywania zaawansowanych technologii i innych możliwości wynikających z posiadanego potencjału. Każde niezależne państwo jest źródłem polityki wewnętrznej i zagranicznej, które mogą zwrócić się w różnych kierunkach, określanych rozmaitymi zasadami lub właściwościami. Realizacja celów polityki zagranicznej wzmocni obopólne korzyści, integrację w sferze ekonomicznej, politycznej, społecznej i kulturowej oraz doprowadzi do konsolidacji wysiłków podejmowanych przez państwa na rzecz rozwiązywania aktualnych wyzwań i problemów.

Słowa kluczowe: gospodarka międzynarodowa a Azerbejdżan, rynki eksportowe, ewolucja handle zagranicznego Azerbejdżanu, relacje ekonomiczne Azerbejdżanu z Polską, współpraca na linii Azerbejdżan-Polska 


\author{
Kamila Rezmer-Płotka \\ Nicolaus Copernicus University \\ ORCID ID: https://orcid.org/0000-0002-1458-5076
}

\title{
Respecting Religious Freedom in India 2014-2018
}

\section{Introduction}

India is described as the world's largest democracy due to its large population ${ }^{2}$. Formally, it is a secular state in which the Bharatiya Janata Party won the 2014 elections $^{3}$, and Narendra Modi, who is considered a conservative and a nationalist, became prime minister ${ }^{4}$. For this reason, it is appropriate to study Indian democracy from the respect for religious freedom perspective. According to successive reports of the United States Commission on International Religion Freedom (USCIFR) in India, violations of religious freedom and

1 This paper is a result of the research project Contentious Politics and Neo-Militant Democracy. It was financially supported by the National Science Centre, Poland [grant number 2018/31/B/HS5/01410].

2 European Parliament, India: the biggest democracy in the world, https://www.europarl.europa.eu/RegData/etudes/ATAG/2014/538956/ EPRS_ATA(2014)538956_REV1_EN.pdf [access: 24.07.2020].

3 O. Laughland, M. Weaver, Indian election result: 2014 is Modi's year as BJP secures victory, https://www.theguardian.com/world/2014/ may/16/india-election-2014-results-live [access: 25.07.2020].

4 A. Wolska, Koronawirus: Indie się duszą. Świat rusza z pomoca, https://www.euractiv.pl/section/bezpieczenstwo-i-obrona/news/indie-koronawirus-pandemia-covid19-pomoc-szczepionki-zakazenia/ [access: 26.04.2021]. 
attempts to create a religious state only for Hindus, are systematically violated ${ }^{5}$. Both the activities of the India Prime Minister and the violations of religious freedom can testify to the progressive process of militant democracy in the country. This process has been observed in the case of the Member States of the European Union since the 2008 financial crisis emergence. Since then, numerous grassroots protests have started to emerge due to the very difficult and poor socioeconomic situation, including even the most popular protest of 2011, which took place in Spain ${ }^{6}$. In the case of India, a different point would have to be set for the purposes of this article - it was assumed that this would be the moment when a man with certain, rather radical views took prime minister office, which could promote this process.

\section{Theoretical and Methodological Background}

Initially, the category of militant democracy was applied by Karl Loewenstein to the Weimar Republic ${ }^{7}$. It concerned a political regime in which the parliament ${ }^{8}$ and the judiciary

5 United States Commission on International Religious Freedom, Annual Report 2020, https://www.uscirf.gov/sites/default/files/ USCIRF\%202020\%20Annual\%20Report_Final_42920.pdf [access: 24.07.2020].

6 J. Rak, Relations between the installation of democracy and the anti-austerity protest behavior. Spanish indignados in comparative perspective, "Aportes Revista De Historia Contemporànea" 2019, vol. 99, no. 34.

7 K. Loewenstein, Militant Democracy and Fundamental Rights I, "The American Political Science Review" 1937a, vol. 3, no. 31, pp. 417-432; K. Loewenstein, Militant Democracy and Fundamental Rights II, "The American Political Science Review" 1937b, vol. 4, no. 31, pp. 638-658.

8 J. Marszałek-Kawa, The Institutional Position and Functions of the Sejm of the Republic of Poland after the Accession to the European Union, Odessa 2019. 
are equipped with legal means to restrict individual democratic freedoms in order to defend democracy against those who are considered its enemies ${ }^{9}$. Among the indicators that allow to analyze modern democracies in terms of the characteristics of militant democracy, one can indicate religious freedom ${ }^{10}$. Democracy has both a defensive function, that is, a willingness to defend against every possible threat, and an offensive democracy that is capable of attacking and destroying, or even incapacitating, if necessary ${ }^{11}$. In this case, for example, believers of other religions may become the enemy of democracy. For this reason, the article answers a research question: what violations of religious freedom occurred in India in 2014-2108? To answer it, the organization's reports (USCIFR) have been analyzed, specifically their sections regarding religious freedom conditions.

\section{Religious Freedom in India in 2014-2018}

In a 2014 report $^{12}$, issued at the breakthrough of 2013-2014, the focus was the record of the considered period. In the

9 K. Loewenstein, Militant Democracy and Fundamental Rights I, op.cit., p. 418; G. Molier, R.B. Rijpkema, Germany's New Militant Democracy Regime: National Democratic Party II and the German Federal Constitutional Courts's 'Potentiality' Criterion for Party Bans: Bundesverfassungsgericht, Judgment of 17 January 2017, 2 BvB 1/13, National Democratic Party II, "European Constitutional Law Review" 2018, vol. 2, no. 14, pp. 394-409.

10 J.-W. Müller, Militant Democracy, [in:] The Oxford Handbook of Comparative Constitutional Law, eds. M. Rosenfeld, A. Sajó, New York 2012, p. 1119.

11 R. Bäcker, J. Rak, Trajektoria trwania opancerzonych demokracji, „Studia nad autorytaryzmem i totalitaryzmem” 2019, vol. 3, no. 41, p. 65.

12 USCIFR, Annual Report 2014, https://www.uscirf.gov/sites/default/files/India\%202014.pdf [access: 28.07.2020]. 
case of described activities without a specific year indicated, they are also included in this article. Earlier this year, several thousand people, mostly Muslims remained displaced in deplorable conditions out of returning to their homes. In addition, explosives detonated in a Buddhist religious complex damaged a temple and sacred tree and injured two monks. Several states have also adopted the so-called "Freedom of Religion Act(s)", which refers to require government officials to assess the legality of conversions and provide for fines and imprisonment for coercive people, which has led to increased hostility towards religious minorities ${ }^{13}$.

In the 2015 report $^{14}$, issued at the 2014-2015 breakthrough, it was pointed out that Christian communities are reporting an increase in persecution and violence against them. First of all, there was physical violence, arson, desecration of churches and Bibles, and disruption of religious services. The local police were supposed to refrain from protecting Christians and accepting complaints from them, and encouraged them not to manifest their religion. Attacks on churches and schools have also been reported. During the considered period, Sikhism was not recognized as a separate religion, preventing its followers from accessing social services or employment and educational preferences that are available to other religious minority communities and to scheduled caste Hindus. In their case, too, there were harassments and pressures to reject their faith, as well as religious symbols. Hindu nationalist groups even announced plans for a forced "reconversion" of Christian and Muslim

13 Ibidem.

14 USCIRF, Annual Report 2015, https://www.uscirf.gov/sites/default/files/India\%202015.pdf [access: 27.07.2020]. 
families, and there was also a case that the church was converted into a Hindu temple ${ }^{15}$.

2016 report ${ }^{16}$ pointed out that persecution and violence against Muslims, who were additionally accused of being terrorists, were continuing to increase, spying for Pakistan; forcibly kidnapping, converting, and marrying Hindu women; and disrespecting Hinduism by slaughtering cows. Hatred and religious tensions were fueled by members of the BJP and RSS, who openly claimed that the growth of the Muslim population was aimed at reducing the Hindu majority. However, there were still so-called Freedom of Religion Act(s), but it turned out that they were theoretically intended to protect religious minorities from forced conversions and, in practice, concerned about conversions away from Hinduism but not toward Hinduism. Sikhs continued to be harassed and persecuted, and if somewhere there were protests over the desecration of the Sikh Holy Scripture, police killed and shot many of the unarmed demonstrators. Dalits also faced discrimination, and they could not enter temples, for example. Religious minorities have reported that religiously motivated attacks are classified by the government as social violence. Numerous cases of harassment and attacks have also been reported by Christians, as well as restrictions on the activities of Government-sanctioned Christian groups. Moreover, Hindu nationalist groups announced plans to "reconvert" thousands of Christian and Muslims families to Hinduism as part of a so-called Ghar Warpsi programme. Sikhism, Jainism, and Buddhism are not seen as separate denomination, for this reason any for-

15 Ibidem.

16 USCIRF, Annual Report 2016, https://www.uscirf.gov/sites/default/files/USCIRF_Tier2_India.pdf [access: 28.07.2020]. 
malities such as marriage registration or adoption of children must be carried out by classifying as Hindus. In this way, they are also excluded from access to social services or employment and educational preferences, which are guaranteed by the religious minority ${ }^{17}$.

In the 2017 report ${ }^{18}$ constitutional provisions that lead to the economic marginalization of Muslims and Dalits. In addition, they were frequent victims of violence. Once again mentioned the "Freedom of Religion Act(s)", the recognition of Sikhs, Jains, and Buddhists to be Hindus, thereby depriving many of the privileges of religious minorities. It is also forbidden to slaughter cows, which is part of the Muslim Festival of the Sacrifice, because of this there has been intimidation, harassment and attacks on Muslims and Hindu Dalits. In addition, registration of NGOs, including Christian humanitarian organizations, was prevented and hindered. There have continued to be harassment and violent attacks on Muslims by Hindu nationalists, citing the accusations made and mentioned in an earlier report (above). Moreover, there were intrusions into temples and forced conversions. Hindu nationalists continued to harass and influence Sikhs to reject religious practices and symbols, treating them as enemies of India rejecting Hindus. In Indian courts, cases of social violence are largely adjudicating, and witnesses were to be intimidated. Hindu Daits were still prohibited from entering temples. Cases of harassment and attacks continued to be reported by Christian communities, churches were burned and clergy were beaten, as well as abductions of followers of other religions, as well as forced

17 Ibidem.

18 USCIRF, Annual Report 2017, https://www.uscirf.gov/sites/default/files/India.2017.pdf [access: 28.07.2020]. 
conversions. In 2016, such reported cases were three times more than in 2015. The RSS reportedly placed signs in train stations throughout India that said Christians had to leave India or convert to Hinduism or they will be killed by 2021 and Yogi Adityanath publicly urged Muslims to leave India and go where "Shariat" law is practiced"

Last report of $2018^{20}$ pointed out that, despite the deteriorating conditions for freedom of expression in the previous year, positive developments had also begun to be seen due, for example, to government entities counteracting growing intolerance in the country. Anti-conversion laws and cases of intimidation and arrests have been mentioned once again. For the first time in the period considered, the report pointed to the media encouraging attacks against believers of other religions. Thousands of NGOs have also been shut down, hindered or prevented. There have still been many cases of forced conversions not only within Ghar Warpsi program. The slaughter of cows has been banned and even there has been a tightening of penalties in several state governments $^{21}$.

\section{Summary}

There were regular violations of religious freedom between 2014 and 2018 in India. Most of the violations were repeated every year and covered all three areas of respect for religious freedom, i.e. freedom to adopt, change or renounce a reli-

19 Ibidem.

20 USCIRF, Annual Report 2018, https://www.uscirf.gov/sites/default/files/Tier2_INDIA.pdf [access: 28.07.2020].

21 Ibidem. 
gion or belief; freedom from coercion; and general right to manifest one's religion or belief ${ }^{22}$. This may indicate a process of militant democracy. However, in order to define India as a state becoming militant democracy, other indicators specific to militant and neo-militant democracies should also be considered. However, the study reveals the scale of the problem of violations of religious freedom in India and explains why India is still at the forefront of countries that violate religious freedom. Undoubtedly, during the period considered, on the basis of an analysis of the reports, other indicators specific to the process of militant democracy could be used, in particular in any case, to identify those who were the enemy threatening the system. Moreover, India, although formally a secular state and therefore religiously neutral, is in practice easy to identify which religious minorities are discriminated against and what religion can be described as the so-called state religion.

\section{Bibliography}

Bäcker R., Rak J., Trajektoria trwania opancerzonych demokracji, „Studia nad autorytaryzmem i totalitaryzmem” 2019, vol. 3, no. 41.

European Parliament, India: the biggest democracy in the world, https://www.europarl.europa.eu/RegData/etudes/ ATAG/2014/538956/EPRS_ATA(2014)538956_REV1_ EN.pdf.

22 Rapporteur's Digest on Freedom of Religion by Belief. Excerpts of the Reports from 1986 to 2011 by the Special Rapporteur on Freedom of Religion or Belief Arranged by Topics of the Framework for Communications, https://www.ohchr.org/Documents/Issues/Religion/RapporteursDigestFreedomReligionBelief.pdf [access: 29.07.2020]. 
Laughland O., Weaver M., Indian election result: 2014 is Modi's year as BJP secures victory, https://www.theguardian.com/world/2014/may/16/india-election-2014-results-live.

Loewenstein K., Militant Democracy and Fundamental Rights I, "The American Political Science Review" 1937a, vol. 3, no. 31.

Loewenstein K., Militant Democracy and Fundamental Rights II, "The American Political Science Review" 1937b, vol. 4, no. 31.

Marszałek-Kawa J., The Institutional Position and Functions of the Sejm of the Republic of Poland after the Accession to the European Union, Odessa 2019.

Molier G., Rijpkema R.B., Germany's New Militant Democracy Regime: National Democratic Party II and the German Federal Constitutional Courts's 'Potentiality' Criterion for Party Bans: Bundesverfassungsgericht, Judgment of 17 January 2017, 2 BvB 1/13, National Democratic Party II, "European Constitutional Law Review” 2018, vol. 2, no. 14.

Müller J.-W., Militant Democracy, [in:] The Oxford Handbook of Comparative Constitutional Law, eds. M. Rosenfeld, A. Sajó, New York 2012.

Rak J., Relations between the installation of democracy and the anti-austerity protest behavior. Spanish indignados in comparative perspective, "Aportes Revista De Historia Contemporànea" 2019, vol. 99, no. 34 .

Rapporteur's Digest on Freedom of Religion by Belief. Excerpts of the Reports from 1986 to 2011 by the Special Rapporteur on Freedom of Religion or Belief Arranged by Topics of the Framework for Communications, https:// www.ohchr.org/Documents/Issues/Religion/RapporteursDigestFreedomReligionBelief.pdf. 
United States Commission on International Religious Freedom, Annual Report 2020, https://www.uscirf.gov/sites/ default/files/USCIRF\%202020\%20Annual\%20Report_Final_42920.pdf.

USCIFR, Annual Report 2014, https://www.uscirf.gov/sites/ default/files/India\%202014.pdf.

USCIRF, Annual Report 2015, https://www.uscirf.gov/sites/ default/files/India\%202015.pdf.

USCIRF, Annual Report 2016, https://www.uscirf.gov/sites/ default/files/USCIRF_Tier2_India.pdf.

USCIRF, Annual Report 2017, https://www.uscirf.gov/sites/ default/files/India.2017.pdf.

USCIRF, Annual Report 2018, https://www.uscirf.gov/sites/ default/files/Tier2_INDIA.pdf.

Wolska A., Koronawirus: Indie się dusza. Świat rusza $z$ pomoca, https://www.euractiv.pl/section/bezpieczenstwo-i-obrona/news/indie-koronawirus-pandemiacovid19-pomoc-szczepionki-zakazenia/.

\begin{abstract}
India is described as the world's largest democracy due to its large population. Formally, it is a secular state, while in practice its dominant religion is Hinduism. Moreover, since 2014, Narendra Modi, considered a nationalist and conservative, has been the prime minister of India. For this reason, the article analyzes Indian democracy from the perspective of respecting religious freedom in 2014-2018. The article aims to answer a research question: what violations of religious freedom occurred in India in 2014-2108? Restrictions on religious freedom and violations of religious freedom may also point to the process of militant democracy. Results: In India there were regular violations of religious freedom between 2014 and 2018. Most of the violations were repeated every year and covered all three areas of respect for religious freedom, i.e. freedom to adopt, change or
\end{abstract}


renounce a religion or belief; freedom from coercion; and general right to manifest one's religion nor belief.

Keywords: India, religious freedom, militant democracy, USCIFR

\begin{abstract}
Abstrakt
Indie są postrzegane jako największa demokracja na świecie ze względu na liczebność swojej populacji. Formalnie są państwem świeckim, jednak w praktyce dominuje w nich hinduizm. Ponadto od 2014 roku duże znaczenie w państwie zyskał uznawany za nacjonalistę i konserwatystę Narenda Modi, poprzez uzyskanie przez niego funkcji premiera. Kadencja jego rządów służy w pracy jako naturalna cezura czasowa (2014-2018) do badania kondycji indyjskiej demokracji w kontekście poszanowania wolności religijnej. Celem analizy jest odpowiedź na pytanie badawcze: $\mathrm{z}$ jakim typem naruszeń wolności religijnej mieliśmy do czynienia w Indiach w latach 2014-2018? Ograniczanie lub naruszanie wolności religijnej jest jednym ze wskaźników procesu stawania się demokracją opancerzoną. Wyniki: w latach 2014-2018 w Indiach miały miejsce regularne naruszenia wolności religijnej. Większość tych działań miała character cykliczny i dotyczyła wszystkich trzech obszarów wolności religijnej, tj. wolności wyboru, zmiany lub odrzucenia wyznania; wolności od przymusu; prawa do manifestowania przekonań religijnych.
\end{abstract}

Słowa kluczowe: Indie, wolność religijna, demokracja opancerzona, USCIFR 


\section{Katarzyna Chałubińska-Jentkiewicz \\ War Studies University \\ ORCID ID: https://orcid.org/0000-0003-0188-5704}

\section{Disinformation and Russian Issues}

Falsehood flies and the truth comes limping after Jonathan Swift

\section{Introduction}

The fundamental element of safety and the lack of insecurity is their communication to the society, which precedes development based on shared perceptions and interpretations of the surrounding reality. With the development of societies, the progress of digitalization in the area of communication and easy transmission of information and data, the individualization and specialization of the message leading to entirely new forms of activity, social media, and messages that are not addressed to the public have become increasingly important. It is related to all events and phenomena relating to the public sphere and its impact on the public sphere, the manner of assessment, as well as the narrative that arises and is considered to be true by particular social groups or societies, as they can identify themselves with it and, finally, treat it as their own - post-truth.

It can be said that the role of the media in defining security matters is linked to the social dimension of defining, identifying, and neutralizing threats. Extending the sphere of security of the state and citizens by the virtual environ- 
ment and the reference to cybersecurity is a natural consequence of the development of communication technologies and related social phenomena centered around acquiring, processing, and distributing information. Such a process usually leads to specific law amendments intended to adapt the legal environment, define new social activity rules in the domain of security, and thus reduce the level of threat. The media are transforming, and it is becoming increasingly difficult to define them.

\section{Media and Security}

Due to the prevalence of the Internet and digital forms of information, classical media such as press, radio, and television have been extended to include news, social media sites, blogs, video upload platforms that allow the simultaneous exchange of opinions, feelings, and observations, i.e., information. These new forms of media are not as institutionalized as the classic ones (regulated with concessions, registers). The Internet has become a place to create own information spaces, being at the same time a new form of media and a new public sphere that does not know territorial, language, or national boundaries. This dimension of the often-uncontrolled expansion of the media space requires a new regulatory approach in terms of security methods and techniques. New forms of threats resulting from malware, identity theft on the Internet, impersonating official websites or phishing, give rise to new social engineering techniques which are applied to obtain information, including illegally, to create new situations which favor specific interest groups, including state actors in the context of international relations. The armed forces of individual states are begin- 
ning to organize forces to protect cyberspace, especially concerning traditional state security institutions and other spheres of state security that affect citizens' daily lives.

The second aspect of issues concerns how the media process information using the attributes of the Internet. It should be remembered that the media space and its new forms are built by people using new methods and instruments. The media of our interest are those related to the broadly defined domain of state security. In the sphere of cyberspace, the so-called social engineering attacks will be discussed. Social engineering techniques themselves and the general mechanisms for defining security issues directly refer to a theoretical statement called constructivism (also known as constructionism). It increases the importance of the means of communication used when interpreting social processes. It is also about framing, i.e., building specific stories by narrators who, using their past real experiences and perceptions, consciously influence social actors' decision-making process. It relates to the negative use of the competences of the media and their users. The revolution came with the spread of the Internet. M. Castells describes the new online media reality as "mass self-communication, decisively increasing the autonomy of the communicating subjects vis-à-vis communication corporations, as the users become both senders and receivers of messages ${ }^{1 "}$. Simultaneously, new threats have emerged, which could dismantle the social system, including the potential undermining of the effectiveness of the government's security policy. In turn, a well-thought-out and toned-down media activity, based on scientific knowledge - not only in the fields of medicine

1 M. Castells, Wtadza komunikacji (Communication Power), Warsaw 2013, p. 16. 
and biology, but also taking into account the achievements of social psychology, sociology, and legal sciences could speed up the neutralization, or at least significantly mitigate the epidemic threat, and at the same time strengthen the effectiveness of the security policy being pursued.

Media broadcast should have a specific form, from the way of speaking, dressing up, and gestures of presenters, editors, and journalists, through the nature of the graphics, charts, and other visuals presented in connection with the threat in question, to the selection of experts commenting on the threat. Any crisis, regardless of the current global situation in connection with the pandemic, may be treated as an opportunity for people who are not qualified and try to present themselves as experts and recommend solutions and ways of behavior that are inadequate to the threat or might even aggravate the danger (e.g., celebrities seemingly committed to strengthening the security policy, but promoting only themselves and their interests). There are also the so-called moral entrepreneurs, i.e., people who have ambitions to assume the role of guardians or managers of morality, using the mass media to make appeals for taking expected actions ${ }^{2}$. A characteristic feature of moral entrepreneurs is their presentation of ready-made and comprehensive solutions ${ }^{3}$, often alternative to officially adopted government security measures. Their activities could initiate an organized form of social action (action groups ${ }^{4}$ )

2 M. Ciesielski, Terroryzm i media $w$ kontekście paniki moralnej (Terrorism and the Media in the Context of Moral Panic), "Kwartalnik Bellona" 2012, no. 2, pp. 176-177.

3 L. Miś, Problemy społeczne: teoria, metodologia, badania, (Social Problems: Theory, Methodology, Research), Kraków 2007, p. 102.

4 Ibidem. 
aimed at a given threat, reinforcing or questioning official measures to neutralize it. The media are becoming the arena for clashing interest groups, whose representatives often pursue conflicting objectives. Virtually every message can have its own overt and covert functions, which are not articulated, including opinions of experts who are genuinely prepared to discuss the situation of an emerging threat or comment on the security measures taken.

The media constantly interact with the public, and, whether deliberately or not, can upset the balance between the public and the State structures implementing their state security policy - both in terms of permanent threats and emergencies requiring extraordinary countermeasures, which require rapid and often direct decisions to be taken by way of fast-track legislation. The rapid introduction of extraordinary rules in social life must require complete legitimacy to implement and respect the new legal standards. In practical terms, it is crucial to consider the media, which, after all, are not limited to professional publishers and editorial offices, but often include social media and forums of various ranges (sometimes greater than television or the press). If media broadcasts are characterized by emotional twists and turns, if the form of discussion is chaotic and focused on doubts, and if the complexity of the threat is disregarded, and its structure is oversimplified, then the communities directly exposed to the prevailing danger may lose their balance. It should be remembered that in most cases, people form an opinion about a given security problem based on their own experience or opinions presented by people they know who come into direct contact with such threats - it is the direct experience that counts. If these two conditions are not met, then the media have an even greater influence on 
public opinion, expand their opinion-forming function, and assume greater responsibility.

\section{Disinformation and Social Media}

Social media, especially open ones, where every user has the opportunity to post their content, which is practically out of the administrators' control, or is controlled selectively and insufficiently, constitute a new type of threat, previously unknown before the advent of the Internet. Such open social media can serve not only to exchange data (opinions, assessments, thoughts, assumptions, interpretations, etc.) within small local communities but can easily get a global reach. The activities of famous figures can exemplify it - actors, artists, people in business, and increasingly often politicians - who, on the one hand, can promote specific products in this way and draw profit from advertising campaigns, but, on the other hand, they can spread their ideas, beliefs, thoughts, interpretations, and theories. The important point is that the boundary between facts and opinions, conclusions, and evaluations is blurred in the mass media, especially in the open social media (such as Facebook, Instagram, Twitter, YouTube). As regards certain categories of recipients, usually the most susceptible to disinformation, the transmission of opinions and suggestions can lead to accepting them as facts - even though it can only be a collection of more or less structured thoughts by a given author about a specific threat or a situation related to measures taken by the governments of individual countries as part of their security policy.

For this reason, and because social media publish content related to all spheres of social life and disseminate it 
in real time, it has become an area of organized activity of interest groups that can threaten national security.

\section{Media as the Instrument of Disinformation}

The problem with modern media is that we do not know how to define modernity and media in general. According to Leszek Kołakowski:

"Without knowing what 'modernity' is, we have recently been trying to move forward from our question and talk about 'post-modernity' (it is an extension or imitation of slightly older expressions such as 'post-industrial society', 'post-capitalism', etc.). I do not know what 'post-modernity' is and how it differs from 'pre-modernity', nor do I have the impression that I should know. And what can come after 'post-modernity'? Post-post-modernity, neo-post-modernity, neo-anti-modernity?"5. Thanks to the media, we can feel both local and global. We rely more on media descriptions than our real experience. We can question any authority, including scientists, because the media constantly provide us with arguments for and against every statement. Since the creation and spread of the Internet, we have been living in a different reality. The Internet dates back to the early 1990s. In 1991, one of the most important dates, the CERN scientists developed the web www standard (Internet History, 2020). The most characteristic feature of this new era is that it is a global world that can communicate with the entire world with one click. This potential has created a new local-global dichoto-

5 L. Kołakowski, Cywilizacja na ławie oskarżonych (Civilisation on trial), [in:] Cywilizacja na tawie oskarżonych (Civilisation on trial), ed. L. Kołakowski, Warsaw 1990, p. 201. 
my, making people both local commune dwellers and citizens of the planet. As Marshal McLuhan said, we live in a "global village", and although he was referring to the era of television, he anticipated the advent of the Internet era ${ }^{6}$.

Anthony Giddens described that we live in the late modern age. It means that we are one foot permanently in the local environment, but the other in the global world: "Although we all live in local environments, the worlds experienced by most of us are truly global"7. Manuel Castells confirmed that statement, looking at it from the other, global perspective: "The social structure is global, but most of the human experience is local, both in territorial and cultural terms"8. Zygmunt Bauman perceived globalization as a reduction of distance in many respects:

This incredible sense of 'filling the world' is commonly referred to as 'globalization'. With transmission speeds reaching limit values - comparable to the speed of light - (including action triggers), the almost simultaneous sequence of cause and effect reduces even the greatest distances and ultimately invalidates the distinction between cause and effect itself. Despite all practical intentions and goals, we all live today in a close, even intimate neighborhood'.

So, we are somewhere between what is local to us and what is global to all of us. Sometimes we feel more local, and

6 M. McLuhan, Galaktyka Gutenberga. Tworzenie człowieka druku (The Gutenberg Galaxy. The Making of Typographic Man), Warsaw 2017, p. 87.

A. Giddens, Nowoczesność i tożsamość. „Ja” $i$ spoteczeństwo w epoce późnej nowoczesności (Modernity and Self-Identity. Self and Society in the Late Modern Age), Warsaw 2012, p. 251.

8 M. Castells, Communication Power, Warsaw 2013, p. 38.

9 Z. Bauman, Społeczeństwo w stanie oblężenia (Society under Siege), Warsaw 2007, p. 18. 
sometimes we take a global perspective. According to Giddens, that is the local-global dialectic or "interplay between participation in local contexts and global trends".

The natural environment for disinformation activities is the information chaos and the emotional nature of media releases, in which various interest groups often clash. Suppose we are dealing with dynamic developments of a situation and the unpredictability of social processes. In that case, it is very difficult, or even impossible in practice, to distinguish the activities of ordinary public actors, including experts, advisors, clergymen, or scientists commenting on a given threat, from deliberate actions inspired by foreign special services or other State actors. Lectures on social psychology often quote the radio broadcast of October 30, 1938, namely, a radio drama based on the book by Herbert George Welles entitled The War of the Worlds, which led to actual unrest among the Americans. The fictitious story broadcast in an appropriate form, using the realities of the late 1930s, made people of a developed democracy believe in the Martians' attack on Earth. Currently, we are dealing with a great variety of media, but at the same time, it is not possible to verify all information provided - especially in Internet forums, blogs, social media, and other news media. The effectiveness of a given disinformation campaign depends mainly on the channels of transmission and the pace of spread. The great anonymity that the Internet gives (at least a sense of being anonymous) makes it easier to foster increasingly bold and abstract hypotheses about the sources of danger. The most difficult phase of any disinformation campaign is the credibility, legitimacy of the main statement, the disinformation thesis. Such legitimacy often occurs when the central thesis on which the whole disinfor- 
mation campaign is based starts to be commented on in the generally available media, employing professional editors and presenters with the largest audience. Even if this is the most absurd thesis, the very fact that a refuted thesis, portrayed as bizarre and unreliable, is commented by experts working for the most opinion-forming Internet portals, radio stations, or television news programmes, makes it more widespread and, therefore, statistically the fact of commenting increases the ratio of the population which accepts and identifies with a given disinforming media release. Effective disinformation permeates facts about the risk (statistical data, scientifically verified or otherwise confirmed facts). The most significant legitimacy is given to the disinformation content when the theses are analyzed or responded to by decision-makers, those responsible for planning and implementing security policy. For example, this can take place at press conferences in response to questions asked by journalists. Then the disinformation is absorbed into the security context, and it does not matter whether a particular decision-maker will dismantle specific information or thesis. It becomes part of the official security discourse.

\section{Disinformation and Activity of Russia}

Democracy is based and depends on the free flow of information. In this respect, we can say that disinformation undermines democracy. Disinformation is an attack on the very heart of democracy. The story about disinformation is about information that is intentionally false in order to manipulate and mislead people. We live in a world where there is no agreed definition of language we use to describe it. 
- Disinformation - the deliberate creation and distribution of information that is false and deceptive to mislead an audience. Fake news is information that one dislikes or disagrees with. For example, Russians were calling Western media fake news long before Donald Trump did. This disinformation is a felony, a mixture of truth and falsity. The Russian are masters of having a kernel of truth in their disinformation. That is in part why it is so effective and hard to fight.

- Misinformation - Information that is false though not deliberately, that is created inadvertently or by mistake.

- Propaganda Information that may or may not be true is designed to engender support for a political view or an ideology. It is also a misleading term. It seems to be morally neutral. Propaganda word - advertising is a form of propaganda. What the United States Information Agency did during the Cold War is defined as propaganda. It is a misdemeanor. It often uses authentic content ${ }^{10}$.

This difference is an important part of the issue. Disinformation is as old as humanity. When the serpent told Eve that nothing would happen if she ate the apple, that was disinformation. However, today, spreading lies has never been easier. On social media, there are no barriers to entry, and there are no gatekeepers. One reason for the rise in global disinformation is that waging an information war is a lot cheaper than buying tanks. Let us compare the return on investment. The democracies are not very good at fighting disinformation. The value of free speech and debate is

10 R. Stengel, Information wars. How we lost the global battle against disinformation. What we can do about it, New York 2019. 
our issue. Our constitutions and laws are focused on protecting free speech. No matter if it is true or false. There is no one solution in our reality around the world. However, there are the same tools - behavioral data analysis, audience segmentation, programmatic ad buying - the same used in advertising campaigns effective. The Internet Research Agency in St. Petersburg uses the same behavioral data and machine-learning algorithms that Coca-Cola and Nike use. Content created by the Internet Research Agency in St. Petersburg reached 126 million people on Facebook and more than 20 million on Instagram. They created a Black Matters Us website and promoted it with content on Facebook, Google+, Instagram, and Twitter. In February 2016, the site had 100,000 subscribers. They created other entities and sites like Blacktivist and Black Guns to promote Black Matters and increase their total number of African American followers.

In 2015, it was established East Stratcom to "address Russia's ongoing disinformation campaigns" through (i) more effective communication and promotion of policies toward the Eastern Neighborhood, (ii) a strengthened media environment in the region, and (iii) an improved capacity to forecast, address and respond to disinformation.

According to East Stratcom's report The Strategy and tactics of the pro-kremlin disinformation campaign June 27,2018 , the pro-Kremlin disinformation campaign has one underlying strategy. Despite the diversity of messages, channels, tools, levels, ambitions, and tactical aims, and notwithstanding its rapidly adapting nature, the strategic objective is the same - to weaken the West and strengthen the Kremlin in a classic zero-sum game approach. While it is essential to be aware of this overarching strategic objective, we also 
need to understand how this objective is translated at the tactical level.

\section{Examples of Publications Replicating False Information by and about Russia}

According to the report Freedom on the net 2020, the sanctions do not seem to have eliminated the threat of Russian propaganda or significantly contributed to building a more secure national information space. It is increasingly clear that the threat of disinformation is not unique to the Russian-controlled platforms that were targeted with sanctions ${ }^{11}$.

The objective in 2014 was to help Russia achieve its military goals in Crimea. European elections and referenda were targeted in 2016 and 2017 to weaken consensus within Europe on the policy toward Russia. Operations with a lower level of ambition are also being conducted. These disinformation operations aim to undermine liberal democracy and to sow and amplify mistrust in credible sources of information (be it governments or mainstream media), in the geopolitical direction of a country, and the work of intergovernmental organizations. This type of disinformation campaign often is under the threshold of attention and overlooked as marginal. However, it can achieve significant results over the long term. These operations can facilitate more visible, short-term operations with a higher level of ambition that targets particular electoral processes ${ }^{12}$.

11 https://freedomhouse.org/report/policy-brief/2019/shouldukraine-drop-sanctions-against-russian-tech-companies.

12 https://euvsdisinfo.eu/the-strategy-and-tactics-of-the-pro-kremlin-disinformation-campaign/?gclid=CjwKCAjwqIiFBhAHEiwANg9szn- 
In this way, fake news is one of the most popular fighting methods in the information war. Russia's social networking sites use untrue facts to ignite Russians' hatred toward the Ukrainian population and their policies. Students of one of the most popular universities in Ukraine have created a website where they fight against Russian disinformation. This page is called - "StopFake". The fact-checking website was launched on March 2, 2014. Lecturers, graduates, and students of the Mohyla School of Journalism and the course for journalists and editors of the Digital Future of Journalism came up with the idea of launching it. The project was joined by journalists, editors, programmers, translators, and everyone who was not indifferent to the fate of Ukraine and its people during the occupation of Crimea and the war in Donbas. Initially, the main goal of this community was to monitor the media to check and refute distorted information and propaganda related to the events in Ukraine. After some time, the project became an information service in which all forms of Kremlin propaganda are carefully analyzed. They are joined by professionals who verify facts, edit information, translate and distribute it in eleven languages: Russian, English, Spanish, Romanian, Bulgarian, French, Italian, Dutch, German, Czech, and Polish. Initially, the website existed thanks to the work of volunteers. Then it operated thanks to crowdfunding.

At the same time, Russia is also forced to fight disinformation. Corrections concerning Russia's political, economic, and social situation are published on the Ministry of Foreign Affairs of the Russian Federation website. For example:

Fl0n2pMBFiiEdhxfW9xNNG1GGo_Ux3euiOpEXn07HN-qG8hEZtvRoCXU8QAvD_BwE. 
The publication is clearly commissioned, anti-Russian propaganda in nature. Apparently, in order to give significant meaning, as well as to try to undermine the diplomatic successes and dynamically strengthen our country's position on the African continent, the authors of the article also decided to talk about the alleged related case of the British company S.L. Magnitsky "Armut Services LLP", which made a money transfer for consulting services of $\$ 2,000$. The United States in an account used by the Honorary Consul of Russia ${ }^{13}$.

"Claims that Russia is engaged in "systematic and deliberate work to spread counterfeit products and thus wreak havoc" sound particularly cynical in light of the domestic political situation in the United States as well as in the context of the growing electoral race. We are confident that the infamous "Russian card" will now be played for no reason".

In response to the article "The Battle of Languages in Ukraine" (Faustin Vincent, Le Monde, February 17, 2021), it has been written that "In Ukraine, the use of the Ukrainian language is not something taken for granted". Ukrainian is spoken, but not all and not everywhere. Just as not everyone and everywhere speaks Irish in Ireland, French in Belgium, or Italian in Switzerland. What to do? Such is the price that any multinational state must pay to protect its integrity: multilingualism or schism.

Increasingly - on a global scale - electronic media, together with traditional media, intensify phenomena such as information manipulation and the creation and dissemination of false information. The mere dissemination of false information is not punishable either. The phenomenon of

13 https://www.lemonde.fr/afrique/article/2020/09/23/au-cameroun-le-consulat-de-russie-au-c-ur-d-une-etrange-affaire-politico-financiere_6053363_3212.html. 
increasing fake news in the digital media space is a threat. The victory in the information clash is not determined by the numerical military advantage or greater physical strike force but by the knowledge of mass communication. Fake news can easily be classified as one of the main information warfare tools, which has been gaining momentum so far. Therefore, in literature, the term "information war" is more and more frequently used. The term "information warfare" means the impact on another country's civil and/or military population by disseminating appropriately selected information. The object of the information war is both collective and individual consciousness. The information impact can take place both in the background of information noise and in the information vacuum.

The implementation of foreign goals turns information warfare into war and sets it apart from mere propaganda. The resources of information warfare are various communication tools - from the media to mail and gossip. This information includes distortions of facts or imposing upon citizens an emotional perception convenient for the aggressor ${ }^{14}$. According to East Starcom's report, "The Russian disinformation campaign is the highest level of seriousness. It is part of Russian military doctrine and accepted by the top hierarchy of the most important Russian state-owned media. It is what differentiates it from other, less aggressive and not explicitly EU-targeted foreign influence operations. Journalists who actively participate in it receive presidential and military awards.

14 O. Wasiuta, S. Wasiuta, Wojna informacyjna zagrożeniem dla bezpieczeństwa ludzkości, [in:] Walka informacyjna Uwarunkowania Incydenty - Wyzwania, ed. H. Batorowska, Kraków 2017, p. 71. 
The state demands, finances, and rewards disinformation activity as a cost-effective method of achieving its objectives. From public statements and budgetary planning decisions, it is clear that this is a strategy for the long term - meaning the knowledge gap can grow ever wider. Among certain audiences, it has already achieved significant results that will not be quickly fixed, and it aims at broadening these affected audiences. The campaign is directly aimed at harming liberal democracy, the rule of law and human rights, and at silencing those institutions, intergovernmental organizations, politicians, and individuals who defend them"15. The disinformation campaign has an unknown number of channels and speakers, some of which are operating in a non-public environment, like closed events, direct messaging platforms, and through people-to-people contacts. The scale encompasses the highest public authorities, diplomatic networks and security services; NGOs, GONGOs; official, "white" Russian media, unofficial, "grey" pro-Kremlin outlets and disinformation-oriented projects financed by pro-Kremlin oligarchs; local extremists and conspiracy theorists; social media trolls and bots; and individuals who simply get persuaded or attracted into the disinformation ecosystem. The campaign has different tactical aims and objectives for different audiences. It will try to find issues in societies that garner most emotions around them, fuel, and amplify these emotions as much as possible - because an audience shaken by strong emotions will behave more irrationally and will be easier to manipulate. It also seeks to confuse mainstream

15 Https://euvsdisinfo.eu/the-strategy-and-tactics-of-the-pro-kremlin-disinformation-campaign/?gclid=CjwKCAjwqIiFBhAHEiwANg9sznFl0n2pMBFiiEdhxfW9xNNG1GGo_Ux3euiOpEXn07HN-qG8hEZtvRoCXU8QAvD_BwE. 
media, balancing conflicting versions of events, turning this virtue of our media against us. It will overload those who try to find more sources of information and denigrate those who call out these tricks.

The disinformation campaign has different perspectives. It can exploit existing divisions or create new, artificial ones: on the more strategic level, like between the EU and NATO or the EU and the US; or at a national level, like between Western Europe and Eastern Europe, or two countries with historical issues. Disinformation messages will often be built around an "element of truth" that will make them more believable and more difficult to call out.

The disinformation campaign has different levels of ambition. The objective in 2014 was to help Russia achieve its military goals in Crimea. European elections and referenda were targeted in 2016 and 2017 to weaken consensus within Europe on the policy toward Russia. However, it is not only about targeting elections or referenda. Operations with a lower level of ambition are also being conducted. These disinformation operations aim to undermine liberal democracy and to sow and amplify mistrust in credible sources of information (be it governments or mainstream media), in the geopolitical direction of a country, and the work of intergovernmental organizations. They will also try to exploit and amplify divisions between different socioeconomic groups based on their nation, race, income, age, education, and occupation. This type of disinformation campaign is often under the threshold of attention and is often overlooked as marginal, but it can achieve significant results over the long term.

Given the number of different messages, channels, tools, methods, targets, and aims - and the significantly higher 
levels of experience in conducting a disinformation campaign and working with European audiences - it is safe to say that when it comes to audience reactions, the disinformers have a highly developed knowledge about our audiences. Most progress in the disinformation campaign seems to be based on trial and error, as evidenced by the example of Sputnik in Scandinavia and by shifts from one target group to another, e.g., in the political spectrum of a given country.

\section{Bibliography}

Bauman Z., Społeczeństwo w stanie oblężenia, Warsaw 2007. Castells M., Wtadza komunikacji, Warsaw 2013.

Ciesielski M., Terroryzm i media w kontekście paniki moral$n e j$, „Kwartalnik Bellona” 2012, no. 2.

Giddens A., Nowoczesność i tożsamość. „Ja” $i$ społeczeństwo w epoce późnej nowoczesności, Warsaw 1991.

Kołakowski L., Cywilizacja na tawie oskarżonych, [in:] Cywilizacja na ławie oskarżonych, ed. L. Kołakowski, Warsaw 1990.

Lachlan P., Magical Disinformation, London 2020.

McLuhan M., Galaktyka Gutenberga. Tworzenie człowieka druku, Warsaw 2017.

Miś L., Problemy spoteczne: teoria, metodologia, badania, Kraków 2007.

Mucchielli R., La Subversion, [in:] Psychosocjotechnika, dezinformacja - oręż wojny (Psychology and Social Engineering, Disinformation - the weapon of war), ed. V. Volkoff, Komorów 1999.

Stengel R., Information wars. How we lost the global battle against disinformation. What we can do about it, New York 2019. 
Wasiuta S., Wojna informacyjna zagrożeniem dla bezpieczeństwa ludzkości, [in:] Walka informacyjna Uwarunkowania - Incydenty - Wyzwania, ed. H. Batorowska, Kraków 2017.

\begin{abstract}
The primary aim of disinformation is precisely to influence groups that are key to the organization of social life and the state's security policy. Strategic groups mean social groups which are of particular strategic or tactical importance to the so-called destabilization agents. It is not about paralyzing or breaking up such groups but about inspiring, organizing, and structuring them ${ }^{16}$ - generally in their interaction with those in power. The objective here is to fuel and exploit the collective sentiments or needs (including ideologies) of target groups. Moreover, such groups may stir up anger, resentment, and disappointment, for example, related to the government's action taken to deal with the threat. Instead of being a filter, the media are a catalyst for social unrest, and it becomes difficult to assess whether the interest group provokes them, or they are an expression of civic opposition and rebellion against the threat and the security policy being implemented. If, in a crisis caused by a threat to the security of the state and its citizens, there is a confrontation between specific social groups, especially those organized around the political system of the state, then not only the security policy being pursued may lose its legitimacy, but the confrontation may affect lower social areas covering entire segments of society and leading to real social unrest. This paper aims to describe the policy and conditions related to disinformation in the activity of Russia.
\end{abstract}

Keywords: social media, human rights, freedom of the net, freedom of speech, disinformation

16 R. Mucchielli, La Subversion, [in:] Psychosocjotechnika, dezinformacja - oręż wojny (Psychology and Social Engineering, Disinformation - the weapon of war), ed. V. Volkoff, Komorów 1999, pp. 111-115. 


\begin{abstract}
Abstrakt
Podstawowym celem dezinformacji jest oddziaływanie na grupy kluczowe w organizacji życia społecznego i polityce bezpieczeństwa państwa. Grupy strategiczne to grupy społeczne, które mają szczególne znaczenie strategiczne lub taktyczne. Nie chodzi o paraliżowanie czy rozbijanie takich grup, ale o inspirowanie, organizowanie i konstruowanie ich - ogólnie w kontekście ich interakcji z rządzącymi. Celem jest podsycanie i wykorzystywanie zbiorowych nastrojów lub potrzeb (w tym ideologii) kluczowych grup. Co więcej, takie grupy mogą wzbudzać złość, urazę i rozczarowanie, np. związane z charakterem działań podejmowanych przez rząd w celu przeciwdziałania zagrożeniu. Media społecznościowe stają się katalizatorem niepokojów społecznych i trudno ocenić, czy są prowokowane przez grupę interesu, czy też są wyrazem sprzeciwu obywatelskiego i buntu wobec zagrożenia i realizowanej polityki bezpieczeństwa. Jeżeli w sytuacji kryzysowej spowodowanej zagrożeniem bezpieczeństwa państwa i jego obywateli dojdzie do konfrontacji między określonymi grupami społecznymi, Celem artykułu jest opisanie polityki i uwarunkowań związanych z dezinformacją w działalności Rosji.
\end{abstract}

Słowa kluczowe: media społecznościowe, prawa człowieka, wolność Internetu, wolność słowa, dezinformacja 